INTER NATIONAL MONETARY FUND
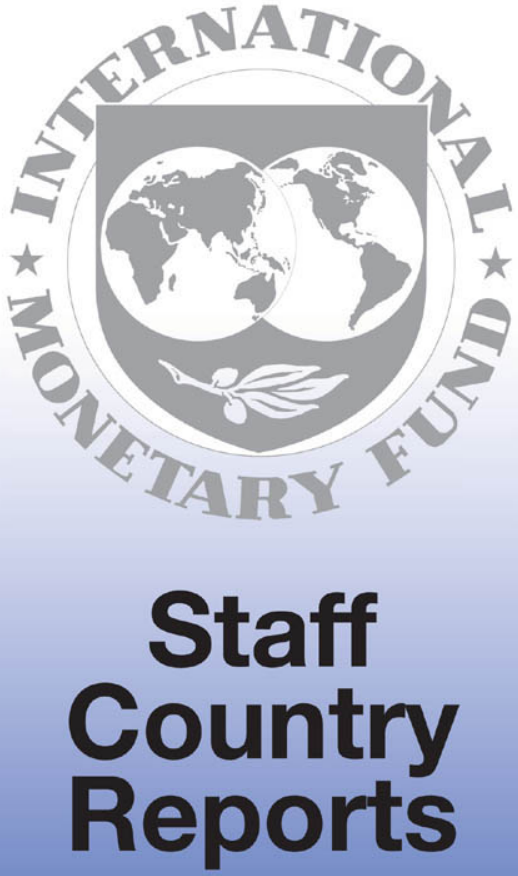


\section{Mali: Selected Issues and Statistical Annex}

This Selected Issues paper for Mali was prepared by a staff team of the International Monetary Fund as background documentation for the periodic consultation with the member country. It is based on the information available at the time it was completed on December 4,2001 . The views expressed in this document are those of the staff team and do not necessary reflect the views of the government of Mali or the Executive Board of the IMF.

The policy of publication of staff reports and other documents by the IMF allows for the deletion of market-sensitive information.

To assist the IMF in evaluating the publication policy, reader comments are invited and may be sent by e-mail to Publicationpolicy@imf.org.

Copies of this report are available to the public from International Monetary Fund - Publication Services 700 19th Street, N.W. - Washington, D.C. 20431

Telephone: (202) 6237430 - Telefax: (202) 6237201

E-mail: publications@imf.org • Internet: http://www.imf.org

Price: $\$ 15.00$ a copy

\section{International Monetary Fund \\ Washington, D.C.}




\section{INTERNATIONAI, MONETARY FUND}

\section{MALI}

\section{Selected Issues and Statistical Annex}

Prepared by a staff team consisting of Mr. Ghura (head),

Ms. Gaye, Mr. Krichene, Mr. Zejan, and Ms. Carvalho (all AFR), Mr. Williams and Mr. Diabaté, respectively Resident Representative and

Economic Assistant to the Resident mission in Bamako

Approved by the African Department

December 4, 2001

Contents

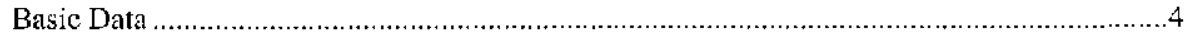

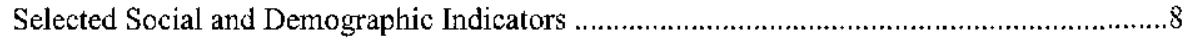

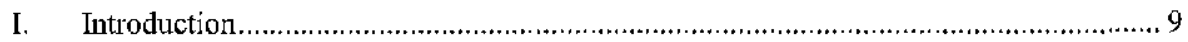

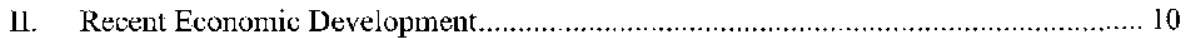

A. Recent Adjustment Efforts and Economic Performance ................................. 10

B. National Accounts ................................................................................... 15

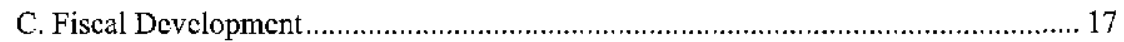

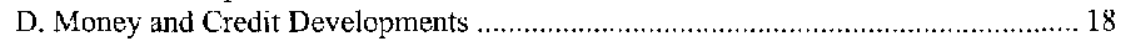

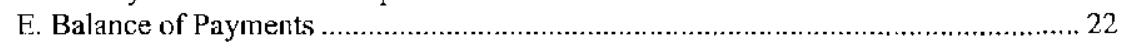

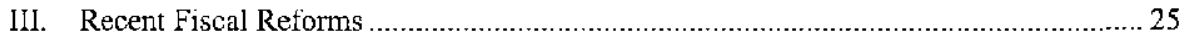

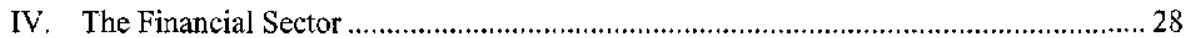

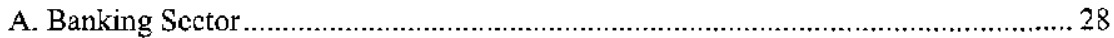

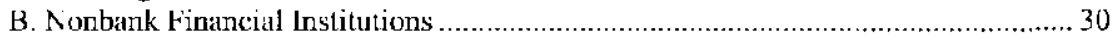

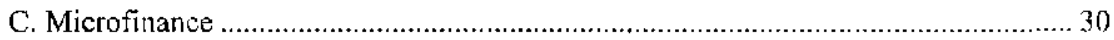

V. Trade Regime .......................................................................................... 33

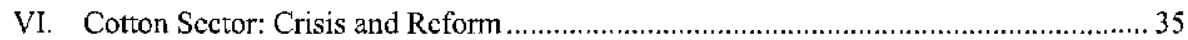

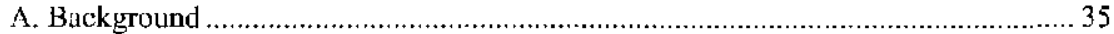

B. Organization of the Cotton Sector....................................................................... 36

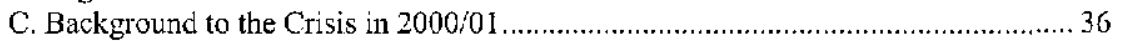

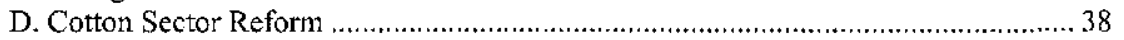

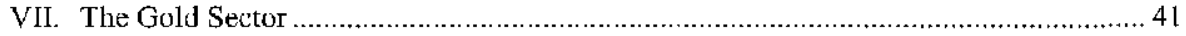

A. Gold Mining .............................................................................................. 42

B. Potential Gold Mining Developments and Mineral Exploration ......................... 43

C. Sector Institutions...................................................................................... 44 


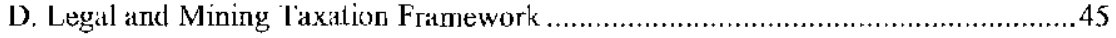

E. Impact of Gold Mining on the Economy .......................................................46

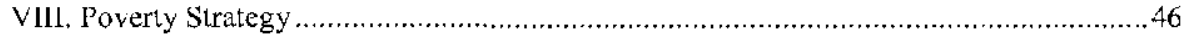

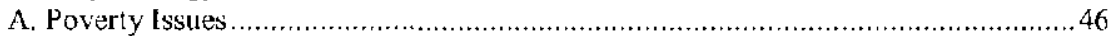

B. Policy Response .................................................................................... 50

Text Boxes

II.1. Sources of Economic Growth .......................................................................13

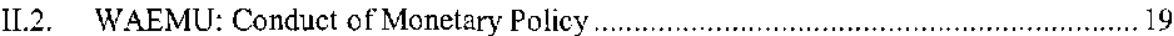

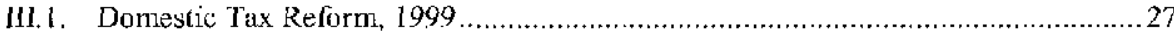

V.l WAEMU: Implementation of the Conmon External Tariff (CET) _........................34

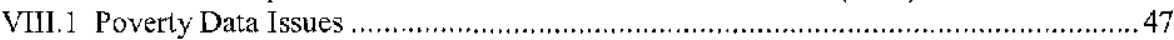

$\underline{\text { Text Tables }}$

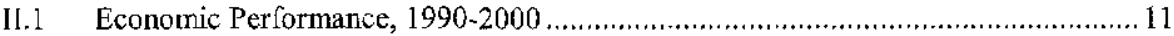

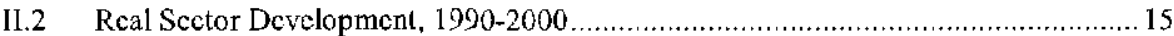

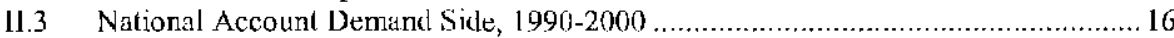

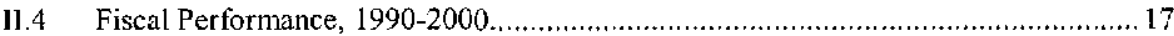

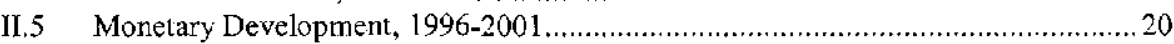

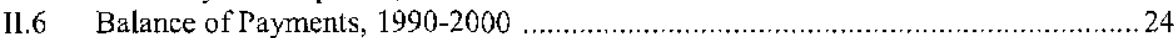

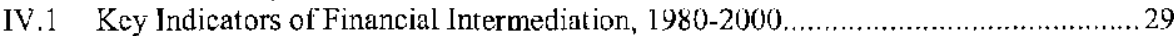

IV.2 Prudential Regulation Situation, December 2000 - June 2001 ...............................31

VI.1 Colton Production, Cont, and Revenue, 1994/95-2000/01 ...................................... 37

VIII.1. Basic Social Indicators for Mali and Sub-Saharan Africa ,...................................47

VIII.2. Poverty Headcount, 1989-99....................................................................48

\section{$\underline{\text { Text Figures }}$}

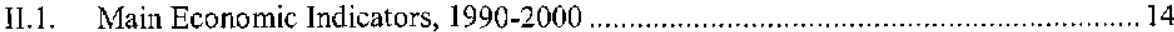

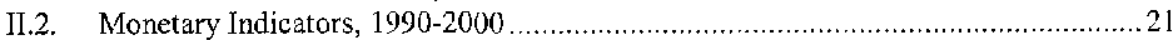

Il.3. Real and Nominal Effective Exchange Rates, January 1990 - August 2001 _...........23

V1.1. Cotton Production and Yield, 1981/82-2000/01 ...............................................35

VI.2. Ratio of Producer Price to World Market Price, 1994/95-2000/01 _........................ 36

VIl.1 Gold Production, 1990-2000 ...................................................................42

Slatistical Appendix Tables

$1 \quad$ Gross Domestic Product at Constant 1987 Prices, 1995-2000 …...............................52

2. Origin and Use of Resources, 1995-2000 ........................................................ 53

3. Agricultural Production and Average Prodlucer Prices,

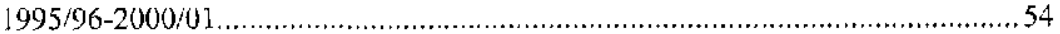

4. Cereals-Cullivated Area and Rainfall, 1995/96-2000/01...................................55 


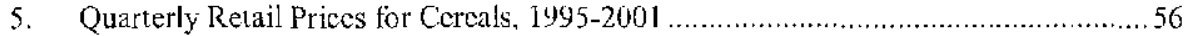

6. Office du Niger-Indicalors of Activity, 1994/95-2000/01 ...................................57

7. Implementation of the Public Investment Program, 1995-2000 .............................58

8. The Investment Budget for 1995-2000 and Existing Commitonents

for Public Tnvestment, 2001-03,........................................................... 59

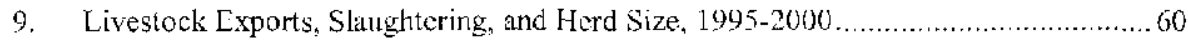

10. Index of Industrial Production, 1995-2001 .................................................61 61

1]. Gold Production by Company, 1995-2000 ..................................................62

12. Production and Cost of Cotlon Fiber, 1994/95-2000/01 .................................63

13. Quarterly Index of Consumer Prices in Bamako, 1998:Q1-20191:Q3 …..................64

14. Minimum Wages and Salaries in the Public Sector, 1995-2000...........................65

15. Employment in the Central atril Regional Governments and

the Public Finterprise Sector, 1995-2000 ...............................................66

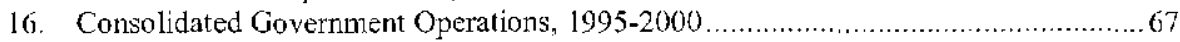

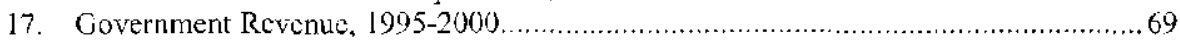

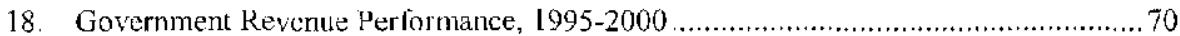

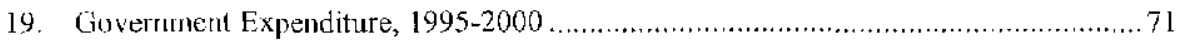

20. Functional Classification of Budgetary Expendil ures, $1995-2000 \ldots \ldots \ldots \ldots \ldots \ldots \ldots \ldots \ldots .73$

21. Consolidated Opcrations of the Special Funds and the Annexed Budgets,

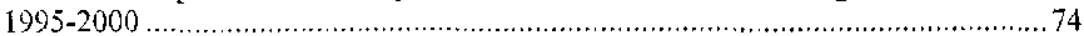

22. Government Wige Bill and Employces, 1995-2000 .......................................75

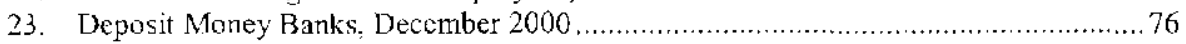

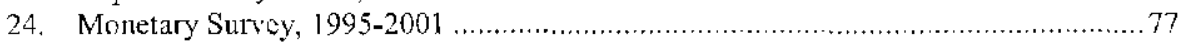

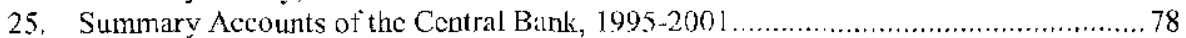

26. Summary Accounts of the I) posit Money Banks, 1995-2001.............................79

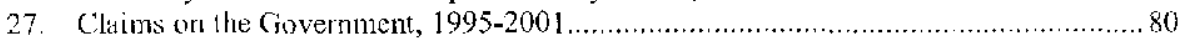

28 . Foreign Assets and Liabilities of the Banking System, 1995-2001 ........................ 81

29. Interest Rate Indicalors, 1995-2001 .......................................................88

30. Central Bank Rediscount Rates, Oclober 1993-September 2001 ...........................83

31. Interest Rates Applied ir the Money Market, March 1995-September 2001..............84

32. Maximun Lending Rates Applied by Conmercial Banks, 1995-2001 _................... 85

33. Balance of Payments, (in CFA francs), 1995-2000 ........................................8 86

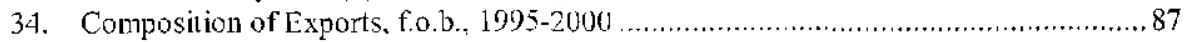

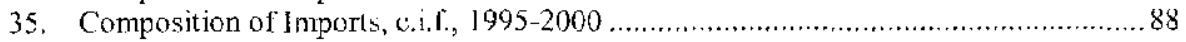



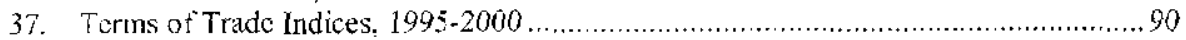

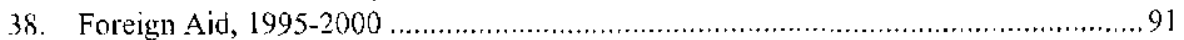

39. External Disbursed Public Debt Oulstanding by Creditor, 1995-2000 ..................... 92

40. Structure and Terms of New L oan Conunitments, 1995-2000,...........................93

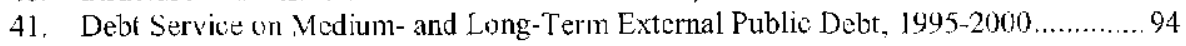

42. Numinal and Real Effective Exchange Rates, 1995:Q1 - 20001:Q3 ......................95

Appendix

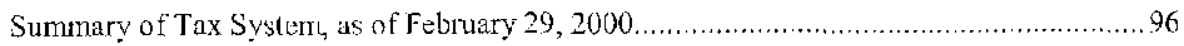


Malı: Basic Lala

Area, popusation, ard GDP per cosita

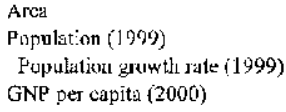

1,2451, 190 square kiJometers

10.6 milling

3.1 percest

US $\$ 240$

\begin{tabular}{|c|c|c|c|c|c|c|}
\hline & 1995 & 1996 & 1997 & 1998 & 1999 & 2000 \\
\hline & \multicolumn{6}{|c|}{ (In hilliuns of CFA francs) } \\
\hline \multicolumn{7}{|l|}{$\begin{array}{l}\text { Gruss doniestic produit al } \\
\text { current prices }\end{array}$} \\
\hline \multirow[t]{2}{*}{ Total (at current prices) } & $1,186.8$ & $1,318.9$ & $\therefore, 422.5$ & $1,592.5$ & $1,670.7$ & $1,811.2$ \\
\hline & \multicolumn{6}{|c|}{ (In percent oinominal GDP) } \\
\hline Consumption & 95.5 & 96.0 & $£ 7.7$ & 88.9 & $91 .:$ & 91.4 \\
\hline Groks dimestic savings & 1.7 & 4.0 & 12.3 & 11.1 & 8.9 & 8.6 \\
\hline Investment & 24.1 & 20.9 & 22.9 & 21.2 & 20.0 & 20.6 \\
\hline \multirow[t]{2}{*}{ Resollice gap } & 22.4 & 16.1 & 10.6 & 10.2 & -11.2 & -12.0 \\
\hline & \multicolumn{6}{|c|}{ (In percent of real GDP) } \\
\hline Primary sector & 47.0 & 44.3 & 43.4 & 42.4 & 43.4 & $44 . \mathrm{L}$ \\
\hline Secondaly sector & 15.6 & 15.8 & 18.2 & 18.5 & 17.7 & 18.2 \\
\hline \multirow[t]{2}{*}{ lertiary sector } & 32.0 & 33.4 & 31.5 & 31.7 & 31.5 & 31.1 \\
\hline & \multicolumn{6}{|c|}{ (Aamul rhange in percent) } \\
\hline Real GDP & 7.0 & 4.3 & 6.7 & 4.2 & 6.7 & 4.6 \\
\hline Notuisal CDP & 21.3 & 11.1 & 7.8 & 12.0 & 4.9 & 8.4 \\
\hline \multicolumn{7}{|l|}{ Prices } \\
\hline GDP deflator & 13.4 & 6.6 & 1.1 & 6.7 & -1.7 & 3.6 \\
\hline \multicolumn{7}{|l|}{ Index of consumer prices } \\
\hline in Bamako & +1.0 & 0,3 & i. 7 & 4.1 & -1.2 & -0.7 \\
\hline
\end{tabular}


Mali : Basic Data (continled)

$\begin{array}{llllll}1995 & 1996 & 1997 & 1998 & 1999 & 2000\end{array}$

Govermuntent firtance

(In billions of CFA francs)

\begin{tabular}{|c|c|c|c|c|c|c|}
\hline Revenue & 157.1 & 205.9 & 229.7 & 254.9 & 272.6 & 260.9 \\
\hline Budgetary revenue & 140.5 & 185.0 & 207.9 & 231.7 & 247.8 & 245.5 \\
\hline $\begin{array}{l}\text { Annexcel bieigets and speci } \\
\text { funds }\end{array}$ & 16.6 & 20.9 & 21.8 & 23.2 & 24.8 & 24.4 \\
\hline Grants & 92.4 & 96.5 & 84.2 & 89.9 & 83.4 & 101.2 \\
\hline Expenditure and net lending & 289.4 & 314.2 & 345.2 & 383.5 & 417.6 & 439.2 \\
\hline $\begin{array}{l}\text { Budgetary expenditure } \\
\text { Of which: externaliy }\end{array}$ & 291.8 & 303.9 & 328.6 & 363.9 & 395.0 & 417.3 \\
\hline financed investment & 133.5 & 137.3 & 124.5 & 149.4 & 147.4 & 157.1 \\
\hline $\begin{array}{l}\text { Annexed budgets and speci } \\
\text { funds }\end{array}$ & 16.6 & 20.9 & 21.8 & 23.2 & 24.8 & 24.4 \\
\hline Overall deficit, commitment & & & & & & \\
\hline Fxcluding grants & -132.3 & -108.3 & -115.5 & -128.6 & $-i 44.9$ & -169.3 \\
\hline Including grants & -39.9 & -11.8 & -31.3 & -38.7 & -61.5 & -68.1 \\
\hline Urcrall deficit. cash basis & -53.9 & -30.7 & -39.7 & -48.7 & -59.1 & -66.5 \\
\hline Finançing (net) & 53.9 & 30.7 & 39.7 & 48.7 & 59.2 & 66.5 \\
\hline Extemal (ne) & 90.9 & 82,2 & 49.0 & 58.0 & 60.3 & 64.4 \\
\hline Banking system (net) & -37.5 & -46.0 & -1.9 & -4.0 & 1.8 & -17.0 \\
\hline Privatization receipts & 1.3 & 0.3 & 1.4 & 1.2 & 10.4 & 20.3 \\
\hline Oiher & -0.7 & -5.8 & -8.7 & -6.4 & -13.4 & -1.2 \\
\hline Monetary survey (end-of-year & & & & & \multicolumn{2}{|c|}{--} \\
\hline Net foreign assets ${ }^{\prime}$ & 147.3 & 190.4 & 183.4 & 150.1 & 113.3 & 167.7 \\
\hline Net domestic assets & 144.1 & 136.1 & 171.5 & 217.1 & 257.8 & 250.6 \\
\hline Medium- and long-term & & & & & & \\
\hline External liabilities & -8.9 & -10.3 & -11.0 & -8.1 & -7.1 & -10.9 \\
\hline Recvaluation account & 1.1 & 1.1 & 1.1 & 1.1 & 1.1 & 1.0 \\
\hline Money and quasi-moncy & 283.6 & 317.3 & 345.0 & 360.2 & 365.0 & 408.5 \\
\hline
\end{tabular}


Mali : Basic Data (continued)

$\begin{array}{llllll}1995 & 1996 & 1997 & 1998 & 1999 & 2000\end{array}$

Balance of payments

(In millions of SDRs)

\begin{tabular}{|c|c|c|c|c|c|c|}
\hline Expots, fob. & 223.9 & 221.4 & 327.7 & 331.1 & 351.6 & 378.5 \\
\hline Imports, c.i.C & -311.2 & -282.1 & -318.6 & -329.3 & -372.8 & -421.4 \\
\hline Services (net) & -176.3 & -149.1 & -156.9 & -159.2 & -161.3 & -170.8 \\
\hline of which: interest & -17.6 & -13.9 & -13.2 & -11.2 & -14.0 & -15.6 \\
\hline Private trans fers (net) & 51.0 & 46.1 & 42.6 & 40.0 & 45.8 & 47.1 \\
\hline $\begin{array}{l}\text { Current account } \\
\text { (excluding grants) }\end{array}$ & -212.6 & -163.7 & -105.2 & -117.4 & $\therefore 36.7$ & $-166 . ?$ \\
\hline $\begin{array}{l}\text { Unrequited pubiic transfers } \\
\text { (uel) }\end{array}$ & 142.1 & 52.3 & 31.1 & 27.6 & 24.1 & 46.4 \\
\hline $\begin{array}{l}\text { Current account } \\
\text { (including grants) }\end{array}$ & -88.2 & -13.3 .4 & -104.2 & -119.7 & -155.8 & -171.2 \\
\hline Capital (nei) & 83.0 & 70.6 & 65.0 & 73.2 & 69.8 & 69.0 \\
\hline Official capital (net) & 38.4 & 41.2 & 33.7 & 58.0 & 60.3 & 61.4 \\
\hline Disbursernerts & 117.6 & 102.1 & 72.7 & 83,9 & 91.7 & 95.0 \\
\hline Amorlization & .79 .2 & -60.9 & -39.0 & -25.9 & -31.4 & -3.3 .6 \\
\hline Private capital (net) & 44.6 & 29.4 & 31.3 & 15.2 & 9.5 & 7.6 \\
\hline Debt :clicf & 59.2 & 55.2 & 19.1 & 0.0 & 0.0 & 0.0 \\
\hline Errors and orrissions & -2.3 & 9.5 & -3.2 & -11.2 & 6.0 & -12.2 \\
\hline Overall balance & 28.8 & 63.2 & -2.0 & -22.6 & -12.7 & 24.7 \\
\hline \multicolumn{7}{|l|}{ Foreign assets (net) } \\
\hline (increases -) & -28.8 & -63.2 & 2.0 & 22.6 & 12.7 & -27.3 \\
\hline Of which: IMF (net) & 18.4 & 10.0 & 9.9 & 1.8 & 6.9 & -5.7 \\
\hline HIPC Initiative assistance & 0.0 & 0.0 & 0.0 & 0.0 & 0.0 & 2.6 \\
\hline
\end{tabular}


Mali : Basic Data (concluded)

$\begin{array}{llllll}1995 & 1996 & 1997 & 1998 & 1999 & 2000\end{array}$

(In millions or U.S. dullars)

Oulstanding extermal debc

(end-uf-period)

Of which: Fund tredit
$2,846.2$

147.2

$2,884.0$

$3,056.4$

2.987 .0

$3,038.0$

164.8

175.7

186.5

193.4

175.5

Debl service ralio

Stheduled iebl service
Excluding the Fund
16.4

14.7

15.1

13.3

11.1

9.8

11.4

9.4

12.9

10.9

13.3

10.4

(CFA trancs per SDR and per U.S. dollar)

\section{Exchange raless \\ Period average \\ SDR \\ U.S. dollar \\ Find of period \\ SDR \\ U.S. dollar}

Trade-weighted cffective exchange rate index
Nominal
Rcal (CPI-bascd)

803.1

$800.1)$

841.9

615.7

938.9

511.6

583.7

590.0

712.0

\section{4}

490.0

753.1

807.9

791.6

896.2

523.7

598.8

562.2

653.0

918.5

705.0

\footnotetext{
'Exciuding SDR allocations and medium-and long-term liabilitics.

"In percent of exports of goods and nonfactor services; after deht cancellation; before debt relief; excluding debt service due to the Pcoplc's Republic of China and Russia.
} 
Mali: Selected Social and Demographic Indicators '

Area

Total (sๆ. km.)

Agricultural (percent of total)

of which : uncer irigation

Population (1999)

I'otal (million)

Average rate of growth (jersent a year)

(1993-99)

Population characteristics

Cruld birth rate (per thousand; 1999)

Crude death rate (per thousand; 1999)

Urhan jopulation (persent of total; 1999)

Access to in improyed water source

In percent of population

Total

Urban

Rural

Nitrition (1998)

Per capita supply of

Calorics (per day)

Proteins (grams per day)
Gross national pioduct (2000)
$1,240,190$

26.4

0.24

10.6

46.2

19.4

29.4

65

74

61
Per capita (USS)

(World Bank Atius methodolngv;

Population density

Uineral density (per sq. Km)

Density per ar. kin. of agrivultural land

IIcallh

Populetion per physician (in thousands, 1996)

Population per hospital bed (1998)

Infant mostality rate (per thousand

live births) (1999)

Fducation

Eurollment ratcs (in pcrecnt of school age population)

Prituary (1999)

Secondary (1997)

12.6

Pupi-teacher ratio (jn percent)

Primary (1908)

79.5

Secondary (1994)

Sources: Word Bank, Social Indicators of Development, 200l, and African Development Indicators, $200 \mathrm{~L}$ and World Development Indicator, 2001 CD-ROM; and ste:T estimales.

${ }^{1}$ Latest sirgle year between 1990 and 1999, unless otherwise indicated. 


\section{INTRODCCTION}

1. Mali is one of the least develaped economies in the world, ranking $153^{\text {rd }}$ out of 162 countries listed in the 2001 United Nations Development Program Human Development Index. A landlocked Sahelian nation of West Atrica, covering an area of about 1.24 million square kilometers, Mali opted for at state-controlled model of economic development shortly after gaining independence in 1960. Since the early 1990s, however, Mali has made significant progress in moving toward a democratic system of government, as well as in promoting peace, stability, and cconomic integration in the region. Mali is a member of the West African Economic and Monetary Union (WAEMU) and participates actively in regional economic integration initiatives that involve reforms in arcas of common interest to the Union.

2. Mali's resident population is estimated at about $10 \frac{1}{2}$ million (in 2000), the vast majority of whom live in rural areas, and depend on food and cash crops and livestock tor their livelihood. The northern half of the country forms part of the Sahara Desert, and ai present contributes little to the country's overall output. The southern half, irrigated by the Niger and Sencgal Rivers, produecs a variety of eash and subsistence crops. Agricultural production suffers from recurrent droughts, poor and fragile soils, and the encroachment of the desert. Mali's mineral resource base is narrow, and exploilation has tradilionally been limited to small-scale gold mining. However, based on recent geological surveys, important gold deposits have been identified and are being extensively exploited (see Chapter VII).

3. Since the early1990s, Mali has madc appreciable progress in reducing macroeconomic imbalances and liberalizing the economy. This has been made possible by consolidating the government fiscal position, lowering inflation, dismantling public monopolies ${ }^{\top}$, abolishing price controls, liberalizing the trade regime, and allowing for a greater role for private sector initiative. The country's adjustment efforts were reinforced with the devaluation of the CFA frane in January 1994, which combincd with fiscal adjustment and structural retorms, improved internalional competitiveness, revived economic growth, and reversed the decline in GDP per capita. ${ }^{2}$

4. Notwithstanding the recent progress made in fostering economic progress, the pace of the country's development remains constrained by a low level of human capital, inadequate infrastructurc, and high energy and telecommunications costs. Diversification of the economy tas been limited, and the industrialization process, which is hindered by high

\footnotetext{
${ }^{1}$ A notable exception to this effort is the monopsonistic structure of the cotton sector, which is now slated for reform and liberalization (see Chapter VI).

2 In January 1994, Mali significantly strengthened it adjustment effort, in consultation with its WAEMU partners, with the devaluation of the CFA franc against the French franc from FF $1=\mathrm{CFAF} 50$ to $\mathrm{FF} 1-\mathrm{CFAF} 100$.
} 
transportation and cnergy costs, remains slow. Physical infrastructure is sparse, underdeveloped, and lacks maintenance. Mali is subject to severe cyclical droughts. In addition, the country"s high dependence on two principal export commodities (cotton and gold) and imported oil, makes the economy vulnerable to terms of trade shocks. The courtry's vulnerability to exogenous shocks came to the fore last year, when economic developments were adversely affected by a crisis in the cotton sector, the hike in oil prices, a drought, and tensions in neighboring countrics. The cotton sector crisis was triggered by depressed world prices for cotton fiber, and compounded by weaknesses in the management. of the Compagrie Malienne pour le Développement des Textiles (CMDT) and the producers' decision to boycott production to protest the low producer price paid by the CMDT (see Chapter VI).

5. Poverty reduction remains the government's priority and its com.mitment in this area reflects a two fold need: (i) to identify policies and instruments geared toward achieving the objective of poverty reduction, and (ii) to adopt appropriate short- and medium-term measures to enable the government to make rational and more effective use of domestic and external resources. Private sector promotion remains central to the government's poverty reduction strategy. To facilitate this diversification process, the Malian authorities are currently identifying a package of measures in the context of preparing the final Poverty Reduction Strategy Paper (PRSP) in order to address issues pertaining to: low labor productivity reflecting the shortage of skilled workers; the inatequacy of physical infrastructures; the high cost of factors of production (energy and telecommunications); the low level of Gnancial deepening; and deficiencies in governance and cfforts to deal with corruption. Furthermore, given the importance of the cotton sector to Mali's economy, the Malian authorities have launched a set of short- and medium-term reforms designed to restructure the CMDT and to liberalize the cotton sector in order to improve its competitiveness (see Chapter VI). The government's stated objective is to ensure that Mali can in the medium term achieve an annual growth rate averaging at least 5-6 percent, which will help to roll back poverty.

\section{ReCENT hCuNOMC DeVElopyent}

\section{A. Recent Adjustment Efforts and Economic Performance}

6. The Malian government started implementing structural adjustment policies in 1986, prompted by disappointing economic performance, which was exacerbatcd by a serious drought over the 1982-85 period. Mali's adjustment efforts gained the financial support of the Fund in 1988, with the adoption of a policy framework paper and strong medium-term macroeconomic policies designed to stabilize the economy, prepared in consultation with the Fund and the World Bank. To add new impetus to this effort, starting in the carly 1990 s, with the change of political régime to a democratic system, the government decided to transform and modernize the economy from a state-controlled system into one increasingly governed by market forces in the context of Fund- and Bank-supported programs. 
7. Mali's collaboration with the Fund has included the successful implementiation of it Stand-By Arrangement, two annual arrangements under the Structural Adjustment Facility (SAF), and thrce thrce-year arrangements under the Enhanced Structural Adjustment Facility (ESAF). In addition, in September 1998, Mali was deemed eligible by the Executive Boards of the Fund and the World Bank to benefit from the Heavily Indebted Poor Country (HIPC) Initiative. Mali's adjustment efforts have generally been sustined, with two exceptions: an interruption in 1991-92 during the transition to a democratically elected government; and between August 1993 and April 1994, owing to prevailing social tensions and the need to develop policies designed to accompany the change in the CFA frane parity in January 1994. Since 1994, the government has completed the remainder of the first three-year ESAF program: negotiated and implemented a successor ESAF arrangement. Mali currently benefits from Fund assistance in the framework of a three-year PRGF arrangement approved in August 1999. Owing to slippages in the implementation of the 1999/2000 PRGF arrangement, there were delays in reaching the completion point under the original HIPC initiative; Mali reached the decision point under the enhanced HIPC initiative on September 6, 2000. Cumulative assistance under the original and enhanced HIPC initiatives would amount to US\$523 million in end-1998 NPV terms (representing a reduction of about 36 percent of the pre-HIPC debt stock).

8. A number of structural reforms have been implemented since tlie early $1990 \mathrm{~s}$, most notably in the areas of price and trade liberalization; tax reform, legal and regulatory reform; and the liberalization of the rice sector. Mali also benefited from the reform of monetary policy and the strengthening of bank supervision at the regional level. The CFA franc was devalued in 1994 at the zonewide level and Mali implemented structural reforms in the postdevaluation period, namcly in the legal and regulatory areas, the public enterprise sector, and more recently, in the areas of privatization of the energy company and commercial banks. In addition, since the second balf of 2001, Mali has been implementing reforms in the cotton sector (see Chapter VI).

9. Since the devaluation of the CFA franc in early 1994, Mali has made appreciable progress in improving the externit price

\begin{tabular}{|c|c|c|}
\hline \multicolumn{3}{|c|}{ Táble II.1. Mali: Economic Performance, 1990-2040 } \\
\hline & $\begin{array}{l}1990-y 4 \\
\text { Average }\end{array}$ & $\begin{array}{r}1995-2000 \\
\text { Ayerage }\end{array}$ \\
\hline & \multicolumn{2}{|c|}{ (Index, 1990=100) } \\
\hline \multirow[t]{2}{*}{ Real etfective excharge rate } & 86.2 & 60.9 \\
\hline & \multicolumn{2}{|c|}{ (Percentage chailge) } \\
\hline Real GDP & 1.3 & 5.7 \\
\hline CPI (period average) & 4.2 & 3.3 \\
\hline Export volume & 6.3 & 12.8 \\
\hline \multirow[t]{2}{*}{ Import volume } & 2.7 & 5.5 \\
\hline & \multicolumn{2}{|c|}{ (In percent of GDP) } \\
\hline Goss domestic investment & 20.6 & 21.6 \\
\hline Gross domestic saving & 4.9 & 7.9 \\
\hline Budgetary revenue & 12.4 & 13.9 \\
\hline Tax tevenuse & 110 & 13.1 \\
\hline Intal expenditure and net lendirg & 26.5 & 23.5 \\
\hline Overall liscal balance (excluding grants) & -11.3 & -8.9 \\
\hline Basic Aiscal balance & -2.1 & 0.6 \\
\hline Current account balarce ${ }^{2}$ & -15.5 & -12.5 \\
\hline Broad money & 22.4 & 23.2 \\
\hline \multicolumn{3}{|c|}{ Source: Malian authorities; and l'und staif estimates. } \\
\hline \multicolumn{3}{|c|}{$\begin{array}{l}\text { 'Defined as total revenue (excluding grants) minus total expenditure } \\
\text { atod net lenting (excluding forcign-financet cepital cxpencliture). } \\
2 \text { Excluding official transfers. }\end{array}$} \\
\hline
\end{tabular}


competitiveness of the economy, reducing macroeconomic imbalances, and alleviating economic distortions through the implementation of strong stabilization policies and broadbased structural reforms. Mali's external competitiveness has been largely maintained during the postdevaluation period (1995-2000), with the real effective exchange rate being about 30 percent below its pre-devaluation level. The improvement in external conpetitiveness provided a significant boost to exports, with volume growth more than doubling on an annual average basis hetween 1990-9.1 and 1995-2000 (Table II. I) and Figure II. I). As a consequence, the current account balance, excluding cxtcrnal grants, improved by about 3 percentage points of GDP on average between these two subpcriods. Further, output growth picked up significantly, with real GDP growing at an annual average rute of about $5 \frac{1}{2}$ percent during 1995-2000, compared with about 1 percent on average during 1990-94. The boost to growh was accompanied by an appreciable intrease in total fictor productivity growth (sec Box II.1). The government intensified its fiscal reform efforts in the postdevaluation period as described in Chapter IIT, and as a result the country's fiscal position was strengthencd. Tax revenue increased by 2 pereentage points of GDP on average between 1990-94 and 1995-2000. In addition, tolal experditure was reduced by 3 percentage points of GT) on average between these two sub-periods. As a consequence, the basic fiscal balance turned into a surplus of about $1 / 2$ of 1 percent of GDP on average during 1995-2000, compared with an average deficit of about 2 percent of GDP during 1990-94. However, the degree of tinancial deepening did not improve appreciably between these two subperiods, with the broad money-GI)P ratio increasing by less than 1 percentage point. Nonetheless, the domestic saving-GDP ratio increased by 3 percentage points, reflecting primarily the positive impact of gains in real income, as well as progress in achieving macroeconomic stability.

10. Notwithstanding the achicvements described above, it bears emphasizing that Mali's cconomic and linancial situation remains fragile, owing to its vulnerability to exugenous shocks, including poor weather and adverse terms of trade shocks. Indeed, as described below, Mali's cconomic performance was adversely affected by exogenous shocks in 2000 , including a crisis in the cotton sector, the hike in oil prices, a drought, and tensions in neighboring countries (Table II.2). In addition, while this report does not describe performance in 2001, it is worth noting that real GDP is expected to stagnite in 2001, owing to the cumulative efrects from last year of the drought and the sharp drop in cotton production. The curren account balance, excluding grants, for 2001 is expected to deterioratc by about 1 percentage point of GDP relative to 2000 on account of the drop in colton cxports and a rise in profit transfer from mining companies.

11. Mali's vulnerability to exugenous shocks points to the critical need to diversify the country: sconomic hase. While Mali has largely maintained the gains in external competitiveness it achieved alter the devaluation of the CFA franc in 1994, the successful diversification of the Malian cconomy will require the development of human catpitat and physical infrastructurc, as well as lower energy and telecommunications costs. The linking of the Malian power grid to the regional Manantali electricily network is expected to keep electricity costs from rising rapidly and to improve its reliability. In addition, the planned liberalization of the telcconnunuications sector would be expected to foster efficicncy gains and reliability of service. The planned increase in outlays from HIPC Init iative-related 
resources to boost human capital and rural infrastructure would help in efforts to diversily the economy, In addition, the authorities should stendfastly implement structural reforms, including the liberalization of the cotton sector.

\section{Box II.1, Mali: Sources of Economic Growth}

A growth accounting framcwork is uscd for the analysis of the sources of economic growth. The following production function is used: $Y=A L^{0 . c} K^{n .4}$, where $Y$ is real GDP, $A$ is total factor productivity (TFP), $L$ is labor, and $K$ is physical capital. The capital stock series was constructed by using the perpetual inventory accumulation franework, and assuming a constant depreciation ralt of 6 percent and a capital-output ratio of 1.5 in 1967.

The train results of the analysis are provided in the acompanying table. These results are fairly robust to small variations in the coefficients uuderlying the production function. It should be noted up-liont however, that ther: are a number of weaknesses to this exercise, most notably the lack of data on the capacity utilization and uncmployment rate, which are nceded to adjust the capital stock and labor force series. respectively. Hence, the results need to be viewed as indicative. They are summarized as follows:

- Factor accumulation cxplained the bulk of output growth jefore the devaluation of the CFA franc in 1994, with little or no role played by total factor productivity. A large increase in capital stock made possible the boost in average output growth between 1980-85 and 198694. Major investment efforts were undertaken to raise cotton production, which increased by about 7 percent per year on atverage during 1986-94, compared with an average decline of about 1 pereent

\begin{tabular}{|lrrr|}
\hline \multicolumn{4}{|c|}{ Mali: Sourves of Economic Growth, 1980-2000 } \\
(In percent)
\end{tabular}
per year in the preceding subperiod.

The bulk of the increase in cotton production was the result of an expansion in acreage.

- The 1994 devaluation provided a significant boost to output growth. While factor accumulation continued to play a large role in the pusidevaluation period $(1995-2000)$, TFP growll played an enhanced role, explaining about one-fifth of output growth. The boost in TFP growth may have partly been the result of the lagged effects of the structural reforms implemented in the early $1990 \mathrm{~s}$.

- Output growth in the postdevaluation perind (1995-2000) was to a large extent export led, with export volume growth increasing from about 6 percent on average during $1986-93$ to about 13 percent during 1995-2000. The contribution to overall growth of the secondary and tertiary sectors was enlanced during the postdevaluation period.

- Maintaining a sustained ren1 GDP growth rate of 5-6 jercent per year in the period ahead would require TFP growth of about $2-2 \frac{1}{2}$ percent per year. The liberalization of the colton sector, as well as efforts to diversity the econony, will be critical in this regard. Competition will need to be introduced and fostered at various stages of cotton production. Boosting annual average potential output growth beyond 5-6 percent will require concerted efforts by the authoritics to diversify the sources of cconomic growth and attract forcign direct investrenent. 
Figure II.1. Mali: Main Economic Indicators, 1990-2000
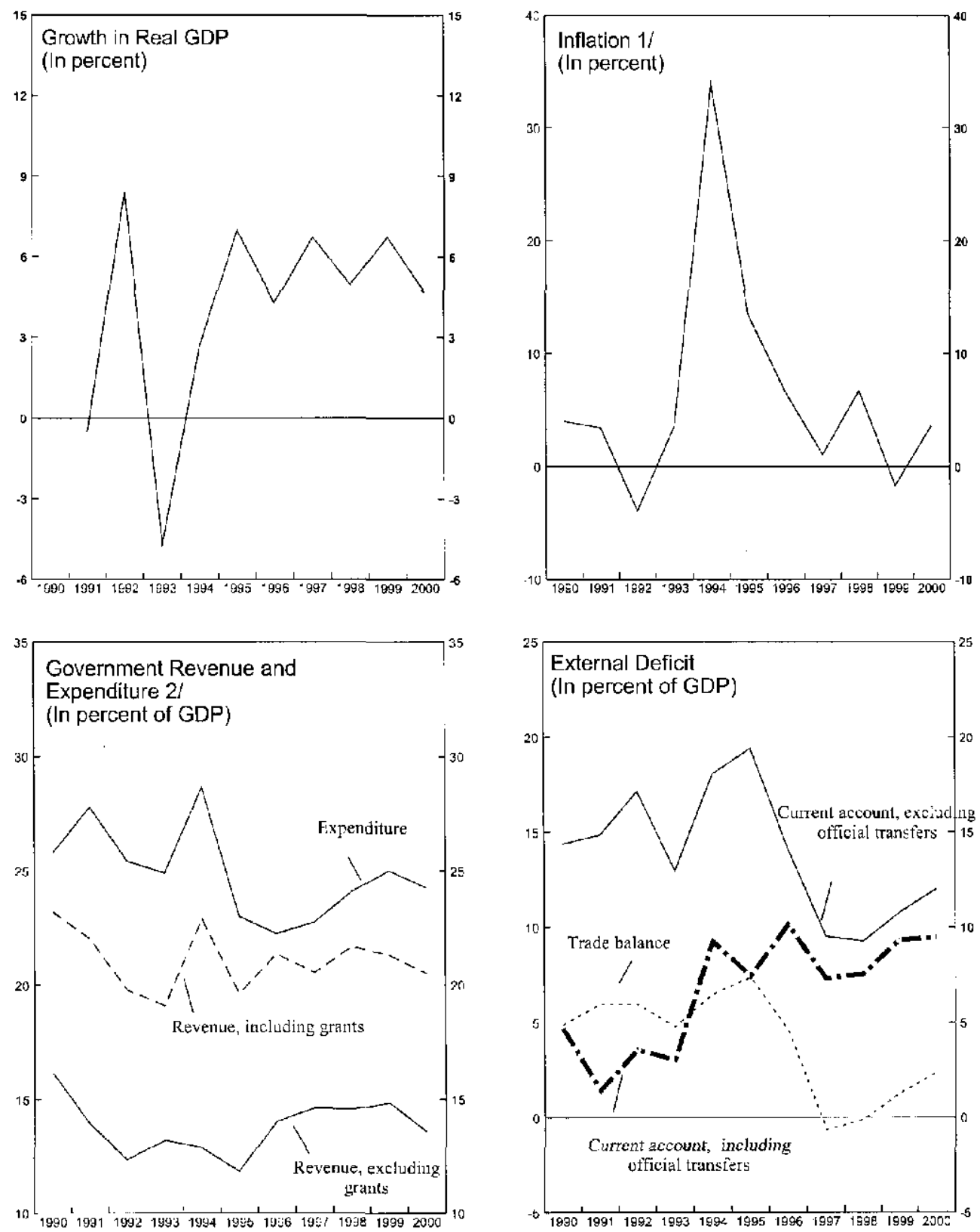

Sources: Malian autboritics; and staff estimates and project:ons.

1/ Pcreentage change in GDP deflator.

2/ Central government on comnitment basis. 


\section{B. National Accounts}

\begin{tabular}{|c|c|c|c|c|c|}
\hline \multicolumn{6}{|c|}{$\begin{array}{l}\text { Table II.2. Mali: Real Sector Development, 1990-2000 } \\
\text { (Percentage change) }\end{array}$} \\
\hline & & $1990-94$ & 1999 & 2000 & $1995-2000$ \\
\hline & & Average & & & Average \\
\hline \multicolumn{2}{|c|}{ Primary scctor } & 1.5 & 9.2 & 6.3 & 4.8 \\
\hline \multirow[t]{2}{*}{ Of which: } & Food crops & 2.6 & 19.7 & 15.7 & 6.0 \\
\hline & Cash crops & -2.2 & 0.1 & $-9,4$ & 10.3 \\
\hline \multicolumn{2}{|c|}{ Secondary sector } & 4.3 & 2.4 & 7.5 & 9.1 \\
\hline \multirow[t]{2}{*}{ Of which: } & lndustry & 1.9 & -4.1 & 11.7 & 5.3 \\
\hline & Mining & 16.8 & 9.8 & 11.1 & 32.0 \\
\hline \multicolumn{2}{|c|}{ Tertiary sector } & 0.7 & 6.2 & 3.2 & 4.2 \\
\hline \multirow[t]{2}{*}{ Of which: } & Transportation & 3.7 & 6.9 & 3.9 & 7.0 \\
\hline & Trade & 0.4 & 10.3 & 3.7 & 5.1 \\
\hline \multicolumn{2}{|c|}{ GUP (at factor cost) } & 1.5 & 6.8 & 5.5 & 5.3 \\
\hline \multicolumn{2}{|l|}{ Import taxes } & -0.7 & 5.8 & -5.8 & 15.2 \\
\hline \multicolumn{2}{|c|}{ GDP (at market prices) } & 1.3 & 6.7 & 4.6 & 5.7 \\
\hline
\end{tabular}

12. Economic developments in 2000 werc adversely affected by the crisis in the colton sector, the hike in oil prices, poor rainfall, and tensions in Côte d'Ivoire. $\Lambda$ large number of cotton farmers boycotted production for the 2000/01 season in protest of the low producer price offered by the CMDT (see Chapter VI). The inability of the CMDT to pay an adequate price to farmers reflected the cumulative effect of the secular price decline of cotton fiber in the world market, as well as poor management of the company, which kept ginning costs relatively high. Rcal GDP growth in 2000 silowed considerably to about 4 percent from 61/2 percent in 1999 (Table II.2). 
13. The demand side of the national accounts reveals a noteworthy adjustment by the government in the postdevaluation period to reduce "excess" consumption and reinforce domestic saving. Government consumption declined on average by 2 percentage points of GDP between $1990-94$ and $1995-$ 2000 , thus enhancing government saving (Table II.3). The fiscal adjustment made by the government, coupled with the boost in exports provided by the devaluation, helped to lower the imbalance in the resource gap.

14. The government's efforts to consolidate its fiscal position helped to lower inflation. The consumer price inflation, which had reached about 24 percent in 1994 (on a period average basis) in the aftermath of the devaluation, quickly decelerated to -0.7 percent in 1997 and remained subdued

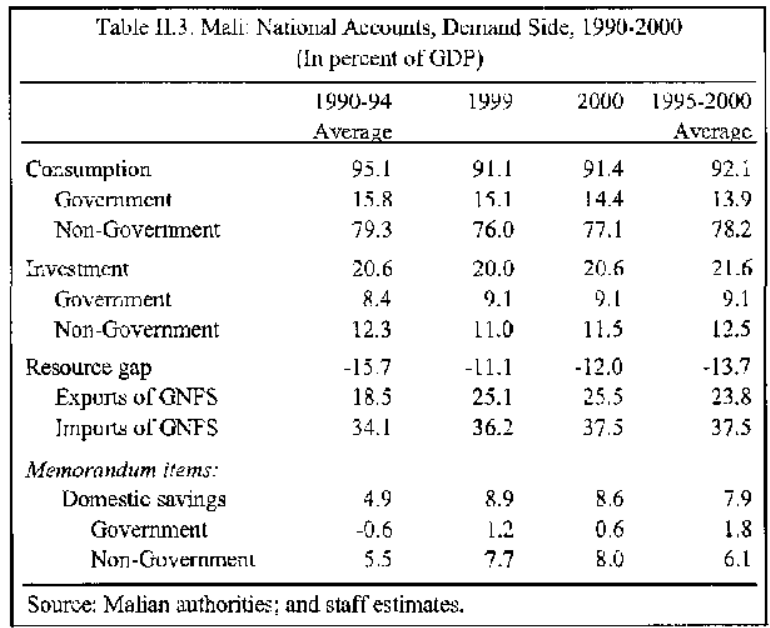
through 2000. Given Mali's membership of the West African Economic and Monetary Union (WAEMU), which has a fixed exchange ratc vis-à-vis the curo, its inflation rate is also influenced to a large degree by the average inflation rate in euro area. ${ }^{3}$. Thus the low inflation environment in Mali over the past few years has been influenced not only by the government's fiscal consolidation efforts, but also by the low inflation environment in the euro area. Nonetheless, short-term inflation in Mali is also influenced by weather shocks. Thus, more recently, reflecting the food shortage that resulted from the drought and the increase in water and electricity rates, price pressures surged during the first seven months of the year, with consumer price inflation reaching 6.3 percent (year on year) in July 2001. However, with the improved prospects for ccreal production this crop season, inflation decelerated to $5 \%$ percent (ycar-on-ycar) in September 2001.

\footnotetext{
${ }^{3}$ The union's currency, the CFA franc was pegged to the French franc at a rate of CFAF 50=FF1 from 1948 until 1994. Effective January 12, 1994, the CFA franc was devalued and the new parity set at CFAF 100=FF1. Effective January 1, 1999, the CFA franc has been pegged to the euro at the rate of $\mathrm{CF} \Lambda F 655.96=$ =Euro $\mathrm{I}$.
} 


\section{Fiscal Development}

\begin{tabular}{|c|c|c|c|c|c|c|c|c|}
\hline \multicolumn{9}{|c|}{ 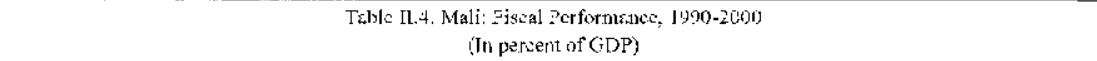 } \\
\hline & 1995 & 1496 & 1997 & 1498 & 1994 & 2090 & 1990.94 & 19952000 \\
\hline & & & & & & & $\Delta$ verage & Averiec \\
\hline Tolal 1evenice and jatuts & 19.6 & 21.4 & 20.5 & 21.7 & $2: .2$ & 20.5 & 22.6 & 20.8 \\
\hline THx Ievtude & $1: .1$ & 13.1 & 13.8 & 13.9 & 14.1 & 129 & 11.0 & 13.1 \\
\hline Expendicure and net 'ensing & 23.0 & $2 \dot{2} .2$ & 22.7 & 24.1 & 25.0 & $2 \leq 2$ & 26.5 & 23.5 \\
\hline Current expenditure & 11.4 & 10.4 & $\mathrm{~L}: 8$ & 10.5 & 11.6 & .1 .0 & $1 \ldots$ & 11.1 \\
\hline Whages sud salaries & 4.0 & 3.8 & 4.0 & $3 . x$ & 3.9 & 4.1 & 5.6 & 3.9 \\
\hline Cepital expendilute & 12.8 & 12.2 & $1: 0$ & 12.2 & 12.0 & 2.0 & $10 . \bar{z}$ & 120 \\
\hline Forejgu-linantes & 11.2 & 10.4 & $8 . s$ & $\$ 4$ & 8.8 & 8.7 & 4.2 & 9.5 \\
\hline Domest:e-finameed & 1.6 & 1.8 & 2.2 & 2.8 & 3.1 & 3.3 & 1.0 & 2.5 \\
\hline Gera.l fiscal bal:unce & -11.2 & $-\$ .2$ & -8.1 & -8.1 & $-x . i$ & $-4: 3$ & $-11 !$ & $-x 4$ \\
\hline Busic fiscal balatice ${ }^{2}$ & 0.1 & 2.2 & 0.6 & 1.3 & 0.1 & .0 .7 & -2.1 & 0.6 \\
\hline \multicolumn{9}{|c|}{ Sodfce: Malian authot:-ies; and Fund statf estinates. } \\
\hline $\begin{array}{l}\text { 1: Toul revenue fexcluding } \\
\text { 1/ Total levenue fexcluding } \\
\text { (excluding foreign-l'tnumed }\end{array}$ & $\begin{array}{l}\text { minus } \\
\text { ininus t } \\
\text { cent). }\end{array}$ & $\begin{array}{l}\text { expendi } \\
\text { expendi }\end{array}$ & $\begin{array}{l}\text { and ne } \\
\text { and ne }\end{array}$ & $\begin{array}{l}\text { ndirig. } \\
\text { adiwg }\end{array}$ & & & & \\
\hline
\end{tabular}

15. Mali made appreciable progress in strengthening public finances in the postdevaluation period (Table II.4). This has been achieved through an enhanced tax revenue mobilization and tight expenditure policies. As a result, the overall fiscal deficil (on a commitment basis and cxcluding grants) narrowed from about 11 percent of GD' in 1995 to about 8 percent in 1998 , before detcriorating in the subscquent two years to reach about 9 percent of GDP in 2000 (sec explanation below). While the basic fiscal balance has been positive on average in the post-devaluation period through 1999, it followed a declining 1rencl. This trend decline can be explained by the fact that, in an effort to strictly control inflation following the devaluation in 1994, there was an "overshooting" of fiscal consolidation between 1994 and 1996. with the basic fiscal balance improving by 5 percentage points of GDP during this period. With inflat ion brought under control at the end of 1996, and with a view to supporting economic activity, the degrec of fiscal consolidation was cascd somewhat starting in 1997, while keeping the basic fiscal balance al a positive level. In addition, the almost sceular decline in the price of eotton fiber in the world market had a negative impact on the contribution of the cotton sector to government tax revenue.

16. The government's fiscal adjustment included a combination of tax and administrative reforms (see section Chapter III) and prudent expenditure policy. Tax revenue increased by 3 percentage points of GDP between 1995 and 1999 , before falling in 2000 (explained below) (Figure 11.2). Over the postdevaluation period, government expenditure was strictly contained, particularly as regards the wage bill and nonpriority spendirg. The wage bill was kept al acound 4 percent of GDP over the period 1995 2000, mainly by a frecze on nel recruiment, except for teachers and healt tr workers. A merit-based promotion system was instituted and vigorously applied, and the payroll and personnel registers werc fully merged 
in order to improve wage bill management. At the same lime, capital expendilure was raised, and in its priority effort to fight poverty, the government raised the share of spending on health and education increased from 3.0 percent of GDP in 1995 to 3.6 percent in 2000 . Finally, social safety net expenditures, previously nonexistent as a budgetary item, were established in 1994 and accounted for 0.6 percent of GDP in 2000 (Figure II.3).

17. The government's fiscal consolidation effort also included the elcarance by 1994 of external payments arrears that were accumulated in the early 1990's. No new external payment arrears have becl accumulated since then. On the domestic front, the stock of domestic arrears at end-1992 has been gradually repaid; the last remaining stock of arrears (about CFAF 9 billion) was fully repaid in 1999.

18. Fiscal performance in 2000 was adversely affected by the increase in oil prices ${ }^{4}$ and the slowelown in the economy. The revenue shortfall for 2000 , cstimated at about 1.4 percent of GDP, is explained by (a) the decision by the authorities to freeze retail petroleum product prices at their March 2000 level; (b) poor customs revenuc performance in the last quarter of the year (reflecting signiticantly lower nonmining imports); (c) the financial crisis in the CMIT) and (d) the effect of the introduction of the common external tariff (CET) the previous year. With the decline in revenue, the basic fiscal balance turned into a deficit of 0.7 percent of GDP.

\section{Money and Credit Developments}

19. Monetary policy, which is conducted at the regional level by the BCE $\triangle O$, is guided primarily by the objectives of preserving the peg of the CFA franc to the euro and consolidating official reserves (see Box II.2). Mali's contribution to the regional official reserves has been positive on average during 1995-2000. In addition, reflecting the fiscal consolidation efforts, the government's net creditor position in the banking system was strengthened on average during this period (Table II.5 and Figure II.2).

\footnotetext{
${ }^{4}$ During 2000, the government continued pursuing its policy of ensuring that retail petroleum prices remained stable. This was accomplished by lowering the effective taxes on petroleum products, to the detriment of government revenue, when the import price increased. This practice was abolished in July 2001, with the adoption of a new tax mcchanism that allowed the automatic pass-through of changes in the import price to the consumer.
} 


\section{Box II.2. WAEMU: Conduct of Monetary Policy}

Monetary policy in the WAEMU is conducted at the regional level by the Central Bank of West African States (BCEAO), which holds the pooled foreign cxchange rescrves of the member states. At lenst. 65 percent of these are kcpt in an operations account with the French Treasury. To support the fixed parity of the CFA franc and its convertibility, the main objective of monetary policy is to ensure price stäbility and miaintain an appropriate level of foreign reserves, with the BCEAO required to keep a minimum level of foreign exchange equivalent to 20) percent of its short-term liabilities (foreign reserve cover ratio).

The fixed exchange rate system and the absence of foreign exchange restrictions imply that the independence of regional monetary policy is constrained as the woney growth within the region is endogenously determined. Moreover, there is nu scope for national monetary policies. For this reason. Fund-supported programs in the WAEMU countries do not include targets for either base money or the central bank's net domestic asscts because these variables cannot be meaningfully defincd at the national lcvel or controlled by the national authorities. Of course, fiscal policy-including public debt management-remains within the purview of individual conntries, and Fund-supported programs typically include targets for the fiscal dcifeil, external borrowings by the govenment, and ntt domestic bank credit to the government. 'lo ensure consistency between the regiunal objectives and national economic and financial developments, the BCEAO conducts an annual financial programming exercise that sets specific targets for crcdit to governments consistent with a targeted level of net domestic assets and gross foreign assets of the central bank.

The BCEAO secks to control domestic credit expansion in the region by using indirect monetary policy instruments and enlorcing ceilings on central bank credit to governments. The policy instruments available to the BCEAO are the discount rate mechanism, a repurchase agreenent facility, and a system of pariodic anctions of central bank bills, as well as reverse auctions, introduccd in July 1996. A system of reserve requirements has also been in place since late 1993. Auctions and repurchase agreements are the most frequently used instruments; the discount rate is used primarily to signal policy intentions about future cuovertents ins interest rates. Ceilings on central bank credit to governmetnts, set at the equivalent of 20 percent of tax revenue in the preceding year, are a powerful tool of credit policy. In its refinancing policy, the BCEAO uses a creditworthiness rating system (accords de classement ${ }^{1}$ ) to guide its refinancing of commercial banks. In September, 1998, the Council of Ministers decided on the elimination of the monetary financing of budget deficits by 2002. Nevcrtheless, within-yenr advances by the central bank to governments will be allowed for smoothing temporary cash-flow fluctuations in line with Article 16 of the statutes of the central bark. In keeping with that decision, the BCEAO has already frozen the ceilings on its statutory advances to governments.

The BCEAO is subject to a full safeguerds assessment with the Stage One report now being circulated for comments by dcpartments. Staff is in the process of obtaining from the BCEAO an authorization letter to speak with externit auditors, which is the only document lett to fully conclude the Stage One assessment.

'A system requiring that at least 60 percent of banks' portfolio include loans to borrowers certified by the BCEAO. While this policy is intended to ensure sound barking practices, 81 of the 84 credit institutions were in violation of the norm at end- 1998 . 
Table II.5, Mali: Monetary Development, 1996-2001

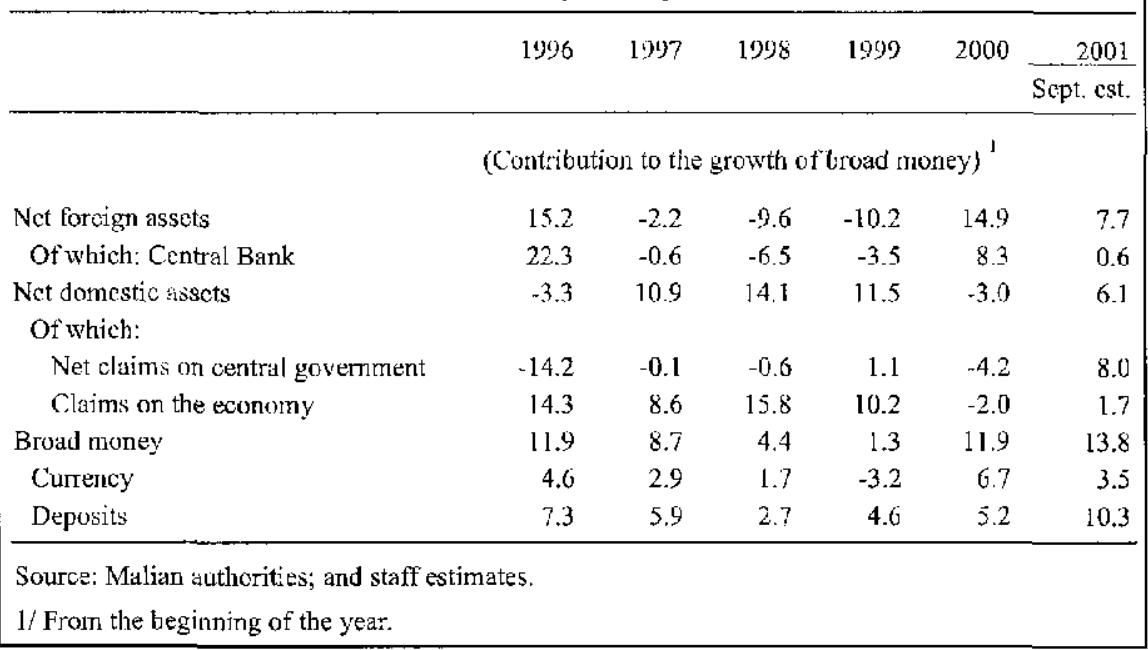

20. In 1999 , broad money increased by 1.3 percent, well below the growth of nominal Gi)P. Reflecting the relatively strong fiscal performance, the government's net creditor position vis-à-vis the banking systen improved somewhat, while credit to the economy expanded by about $14 \frac{1}{2}$ percent. This latter development was partly related to the financial difficulties in the cotton sector, which resulted in delays by end-1999 in the repayment of crop credits. Excluding these unpaid loans, credil to the private sector rose by about $81 / 2$ percent. As a result of these developments and the weakening of the external position, the net foreign assets of the banking system registered a decline of about 10 percent in terms of beginning-of-period money stock, and Mali's contribution to the net forcign reserves of the BCEAO declined in 1999 (Figure Il.4).

21. In 2000 , the net foreign assels of the banking system increased sharply by about 15 percent in terms of beginning-of-pcriod money stock, reflecting significant inflows of budgetary assistance and a reversal in the decline in commercial bank's net forcign asscts. This reversal followed the increase in the intervention rate implemented by the $B C E \triangle O$ in June. The $\mathrm{BCEAO}$ raised the intervention rate by 75 basis points to $6 \frac{1}{2}$ percent in response to the ripid growth of credit in the union. The counterpart of the increase in net foreign assets was a rise in broad money of about 12 percent. Credit to the economy fell at the end of 2000 , owing to a depressed dcmand as the cconomy started to weaken. Net credit to the government was also sharply down because of increased deposits from privatization receipts and aid inflows. 
Figure II.2. Mali: Monetary Indicators, 1990-2000

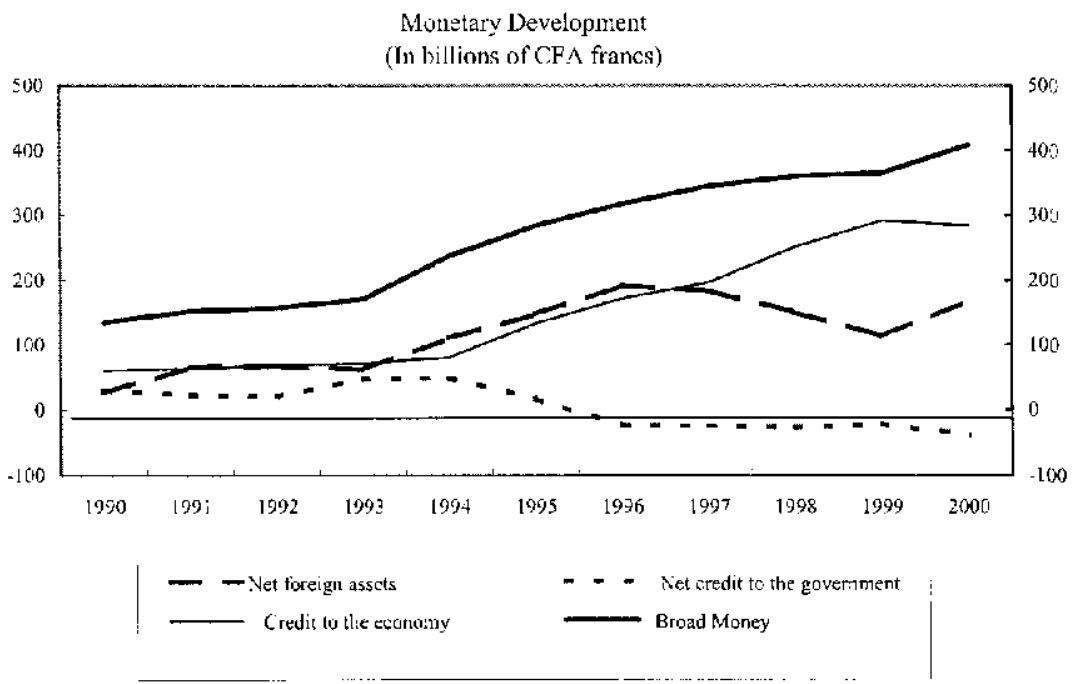

Interest Rate Indicalurs

(In percent)

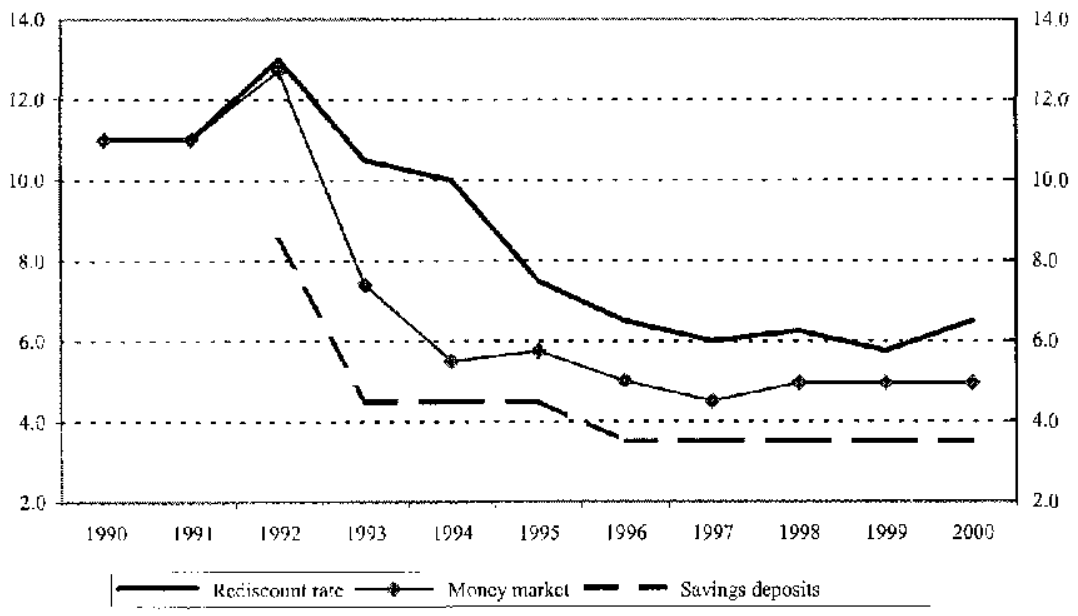

Source: Malian authorities. 
22. Preliminary data through September 2001 (latest available) indicate that the net forcign assets of the banking system increased by about CFAF 31.5 billion from end-2000, mainly because of the surge in the net foreign assels of the conmercial banks. This movement marked a reversal in the decline in these banks' net foreign assets (observed through May 2000), following the increase in the intervention rate at the regional level. ${ }^{5}$ The net domestic assets (NDA) of the banking system increased by about 6 percent since end2000 , with credit to the economy increasing by about $1 \frac{1}{2}$ percent. The bulk of the increase in the NDA was on account of a surge in net eredit to the government, following the crisis in the cotton sector and the need to resolve it (see Chapter VI).

\section{E. Balance of Payments}

23. The devaluation of the CFA franc in 1994 provided a significant boost to Mali's external competitiveness. This in turn helped to strengthen the country's external position and attract forcign direct investment, especially in the gold sector. The nominal effective rate has been fairly stable since the devaluation of the CFA frane in January 1994, falling by about 4 percent until August 2001 (Figure II.3). This movement reflects the exchange rate peg to the French franc and the high proportion of Mali's trade with the European area and other WAEMU countries. The real eflective exchange rate index, based on consumer price indices, appreciated in the two year following the devaluation, but subsequently depreciated by 101/2 percent between August 1996 and August 2001. In August 2001, the index was about 34 percent below its predevaluation level.

24. There was a noticeable surge in Mali's main cxport products (cotton and gold) on avcrage from 1990-94 to 1995-2000 (Table 11.6). In addition, while inports sugged, its rate of increase was lower than that of exporls, resulting in a net improvement in the current account balance (excluding official transfers) between these two subperiods. Nonetheless, more recently, with the slowdown in cotton production, coupled with a decline in the international prices of Mali's main commodities, the current account deficit (excluding ufficial transfers) has deteriorated, from about 9 percent of GDP in 1998 to 12 percent in 2000.

25. Cotton atcounts for almost one-half of total exports and has a large impact on the trate and current account balances (Figure II.5). Cotton production declined from levels in both $1997 / 1998$ and $1998 / 99$ of more than 500 thousand tons to 459 thousand tons in 1999/2000 and 243 thousand tons in 2000/01. As a result, the volume of ginned cotton exports showed a trend dectine. This was exacerbated by the secular decline in world cotton price since 1995 , declining by about 40 percent (in U.S. dollar terms) on a cumulative basis during 1995-2000.

\footnotetext{
${ }^{5}$ The BCEAO raised the intervention rate by 75 basis points to $61 / 2$ percent in June 2000 in response to the rapid growth of credit in the zone.
} 
Figure II.3. Mali: Real and Nominal Effective Exchange Rates, January 1990 - August 2001

(Period average; 1990-100)

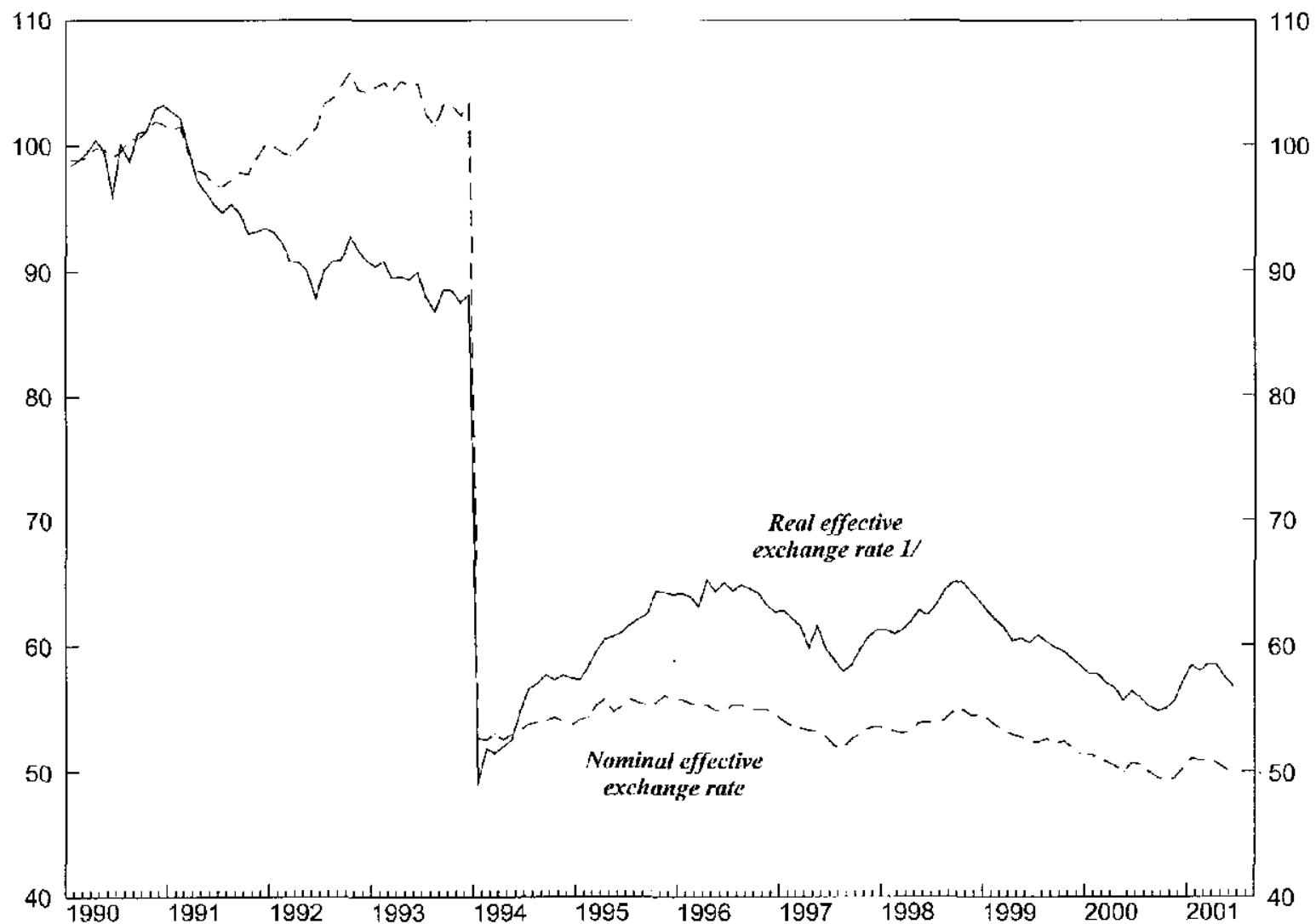

Source: IMF, Infarmation Notice System.

$1 /$ Based on relative consumer price indices.

CInternational Monetary Fund. Not for Redistribution 


\begin{tabular}{|c|c|c|c|c|c|c|c|c|}
\hline \multicolumn{9}{|c|}{ Table II.6. Malı: Baldzete of Paycenls. 19S0-2000 } \\
\hline & $\begin{array}{l}1990-94 \\
\text { Average }\end{array}$ & 1995 & 1996 & 1997 & 1998 & 1999 & 2000 & $\begin{array}{r}1995-2000 \\
\text { Averaze }\end{array}$ \\
\hline & \multicolumn{8}{|c|}{ (ln percent of $(\mathrm{j} D \mathrm{P})$} \\
\hline Exports, fub & 15.2 & 18.9 & $16 . \overline{8}$ & 23.0 & $20 . \dot{8}$ & 21.9 & 20.9 & 20.2 \\
\hline Cotton & 6.8 & 10.9 & 10.2 & 11.3 & 9.5 & 9.2 & 6.2 & 9.5 \\
\hline Guld & 2.2 & 3.0 & 3.0 & 8.2 & 8.4 & 8.5 & 10.5 & 6.9 \\
\hline Othct & 6.2 & 5.0 & 3.5 & 3.5 & 3.0 & 3.4 & 4.2 & 3.8 \\
\hline Itrpo:ta, fib & 20.8 & 26.2 & 21.4 & 22.4 & 20.7 & 22.3 & 23.3 & 22.7 \\
\hline Trakt halaricu & -5.6 & -7.4 & -4.6 & 0.6 & 0.1 & -1.3 & -2.4 & -2.5 \\
\hline Services, yet & -.2 .1 & -14.9 & -11.3 & .11 .1 & .90 .4 & -9.7 & -4.4 & -11.0 \\
\hline Factor services, $1 \mathrm{c} !$ & -1.3 & +1.5 & -1.7 & -2.1 & -1.9 & -2.6 & -2.8 & -2.1 \\
\hline Transfers, net & 14.6 & 16.3 & 7.5 & 5.2 & 4.2 & 42 & 5.2 & 7.1 \\
\hline \multicolumn{9}{|l|}{ Current account balance } \\
\hline [nzluding official transfers & -4.4 & -7.4 & -10.2 & -7.3 & -7.5 & -9.3 & -9.5 & -8.5 \\
\hline Excluding official transfers & -15.5 & -19.4 & -14.1 & -9.5 & -9.3 & -10.8 & .12 .0 & -12.5 \\
\hline Capita! and financial account, net & 5.8 & 10.1 & 14.2 & 7.4 & 6.8 & 8.2 & 11.5 & 9.7 \\
\hline \multirow[t]{2}{*}{ Ot which: lioreign direst invers : ment } & -0.3 & 1.8 & 1.7 & 2.9 & 0.3 & 0.0 & 5.8 & 2.1 \\
\hline & \multicolumn{8}{|c|}{ (Percentage change) } \\
\hline Exporl volure & 6.3 & 14.7 & 0 & 47.1 & -0.1 & 17.4 & $-2 . .3$ & 12.8 \\
\hline Cotton & 3.3 & 35.6 & 8.7 & 26.1 & -12.4 & 24.6 & -19.6 & 10.5 \\
\hline SGold & 15.7 & 33.9 & 6.9 & 180.7 & 23.5 & 11.0 & 31.6 & 44.6 \\
\hline Import vilume & 2.7 & 20.7 & -7.6 & 8.3 & 5.6 & 8.0 & -1.9 & 5.5 \\
\hline Tencs of tratle: & -1.6 & $2, \phi$ & -9.9 & $-(1) .7$ & 33 & $-17 x$ & -1.4 & -2.3 \\
\hline \multicolumn{9}{|l|}{ Memorandum isems: } \\
\hline \multicolumn{9}{|l|}{ Conmodity prices } \\
\hline Cotton (Lis cents per pound) & 88.1 & 98.3 & 80.5 & 79.2 & 65.5 & 53.1 & 59.0 & 72.6 \\
\hline Gold (US dollar pe: fize ounce) & 362.4 & 387.2 & 387.8 & 331.1 & 294.1 & 278.9 & 279.2 & 325.9 \\
\hline
\end{tabular}

26. Endowed with significant gold deposits, Mali has developed into Africa's thirdlargest gold producer and exporter, after South Africa and Ghana. Since 1991, with the reform of the Mining Code, Mali has succeeded in creating an environment conducive to international exploration and mining company operations (see Chapter VII). Following the commissioning of the Sadiola Hill minc in 1997, gold became Mali's second most important export commodity, surpassing cotton in 2000. Currently, gold is mined at Sadiola Hill (Mali's largest gold-mining operation), Syama, Morila, and Orpaillage. Morila started production and cxports in 2000 , producing 3.5 tons in that year. Fven though the strong decline in international prices in 1998 and 1.999 slowed exploration and delayed production start-ups, the value of exports of gold increased from CFAF 133 billion in 1998 to almost CFAF 190 billion in 2000 (Statistical Appendix Table 11). Based on the production capacities of Sadiola mill and Syama, the stable production at Orpaillage of about 2.3 tons per year, and a substantial increase in production in Morila, Mali is expected to export about 50 tons of gold in 2001, valued at about CFAF 326 bilion. 
27. The strong growth in imports observed during 1995-2000 (an annual average rate of $5 \%$ percent) reflects imports related to foreign-financed public investment, and private investment in the mining and construction sectors. Import of machinery and equipment (including in the mining sector) increased from $8^{1 / 2}$ percent of GDP in 1995 to almost 10 percent in 2000. Food imports, which had risen substantially in 1998 as a result of poor cercal crops, returned to normal levels in 1999 , owing to good harvests of cereals. The valuc of petroleum imports increased from 3.7 percent of GDP in 1995106.7 percent of GDP in 2000 because of high international prices.

28. The deficit in factor services account surged from about 2 percent of GDP in 1998 to about 3 percent in 2000 . This reflected the increased transfer abroad of profits by mining conpanies (owing to the surge in foreign direct investment in the sector in previous years). Official transfers also recovered in 2000 , mainly owing to a surge in budgetary support (from about CFAF 19 billion in 1998 to CFAF 32 billion in 2000). The capital account, which includes mainly official project grants, has becn stable since 1998 at about CFAF 70 billion, with fluctuations depending largely on the execution of the public investment program. Since 1994, therc have been large fluctuations in the financial account, owing to sharp swings in foreign direct investment and loan disbursements related to the adjustment program. Preliminary data for 2000 indicate that forcign direct investment reached a record level of CFAF 105 billion ( 5.8 percent of GDP) while loan disbursements, mainly project financing, have been increasing steadily since 1997. As a result of these developments, the inflow of medium- and long-term capital strengthened over the period 1998-2000. Short-term capital have recorded net inflows since 1999.

\section{RECENT FISCAL REFORMS}

29. In the early 1980s, government revenue was heavily dependent on direct taxes, especially laxes on international trade. The tax system was characterized by excessive dependence on specific excise taxes, as well as export and import taxes assessed on administrative values. It was also characterized by a large tax-exempt sector, whose imports and domestic turnover accounted for a significant share of industrial and commercial activity, as well as cxccssivc adhoc cxcmptions. These factors contributed to the weak revenue performance throughout most of the 1980s.

30. Since the mid-1990s, a comprehensive tax reform has been implemented to rationalize the tax system and improve tax administration, with a view to producing a sustained improvement in government revenue performance. Key measures have included: (1) sirengthering of the customs administration through computerization; (2) assessment of import duties on actual rather than administrative values; (3) verification of import value by a reputable international firm to reduce underinvoicing; (4) reduction of ad hoc cxemptions: (5) opening of additional tax centers; and (6) improved monitoring of tax obligations and payments. The sales tax has been replaced with a VAI and a special tax on services (TPS) similar to the VAT; customs duties were rationalized. 
31. Immediately following the devaluation of the CFA franc of 1994, important measures were taken to broaden the tax base, durably strengthen tax collection, and reduce exemptions and tax evasion. At the same time, to limit domestic cost increases in the wake of the devaluation, certain duties and incone tax rates were reduced. In particular, the maximum curnulative irrport tariff rate was reduced from 61 percent to 36 percent, personal and corporate income tax rates were lowered, and the nomal VAT rate was reduced from 17 percent to 15 percent. In 1995 , the number of goods exempted from the VAT or subject to the reduced rate was significantly lowered. In addition, a large-taxpayer unit was established to improve monitoring of the largest enterprises beginning in 1996, and computerization of the tax departments was introduced. In 1997, a common taxpayer identification number system was implemented for use by all tax collection agencies, with a view to enhancing compliance.

32. These reforms were reinforced in 1998 and early 1999 with the implementation of the common external tariff (CET) by WAEMU member countries. The CET involves merging the customs duty and the fiscal duty into a single customs duty, and reducing tariff protection through the introduction of four rates.

33. To modernize the tax system and offset the potential customs revenue loss related to the introduction of the CET, which is estimated at 1 percent of GDP in 1999 and 2000, the authorities have prepared a comprehensive domestic tax reform, including a single-rate VAT of 18 percent (Box III.1). At the same time, measures have been taken to further improve the customs and tax administrations. Taxpayer compliance has been enhanced by cxtending the scope of registration on the basis of a single identification number for each taxpayer, which allows for better cross-checks of tax files between the customs and tax administrations.

34. The Malian authorities have inplemented most of the reforms required to improve the structure of the tax system with the adoption of the common external tariff (CET) and a single-rate valuc-added tax (VAT). Other tax reform measures are in the pipeline, particularly an increase in a number of excise cluties, as well as the harmonization of the BIC rale with a view to raising tax revenues. Moreover, the administrative measures being taken will be strengthened. Accordingly, since January 1, 2001, the single taxpayer identification number has been used systematically by all tax administrations - a practice that has inproved communication among the various assessment and collection agencies. Furthermore, the National Directorate of Tixes (DNI) has launched a procedure to bring the informal sector inlo the tax base and has allocated additional resources to units responsible for tax assessments, which should improve the tax yield. The government will continue its effort to strengthen the capacitics of the various tax administrations through the use of data processing tools, transport equipment, antl professional training.

\footnotetext{
${ }^{6}$ The CET was implemented by all WAEMU member countries on January 1,2000 ; it comprises duty rates at zero percent, 5 percent, 10 percent, and 20 percent, respectively, with, in addition, a statistical tax of 1 percent.
} 


\section{Box III.1. Mali: Dumestic Tax Reform, 1949}

The Malian authorities have implemented in 1999 a comprehensive reform of direct and indirect taxation and a number of administrative measures.

lhe reform of the system of direct taxation includes the following:

- elimination of the progressive surtax in the form of the gencral income tax (IGR) with the introduction of a single proportional scheduler tax on current income, including the tax on industrial and commercial profits (BIC);

introduction of a tax on wages and salaries (ITS) at progressive rates, withheld at the source; and

application of a global tax (taxe synthétique) for taxpayers whose annual turnover does not exceed CFAF 30 million.

The reform of indirect taxation includes the following measures:

- replacement of the existing two-rate VAT (10 percent and 15 percent), the tax on services (TPS) of 15 percent, and the customs service fee (CPS) of 5 percent on imports by a singlc-rate VAT of 18 percent; and

- limitation of the list of goods exempted from VAT to modical supplies, educational materials, and agricultural inpuls.

With respect to administrative measures, the authoritics bave taken a number of steps:

- elininated any remaining excmptions not based on international agrements;

- strengthened operational controls at customs, as well as the procedures for goods in transit and in warehouses;

gcneralized the new fiscal registration system;

improved the processing of large-taxpayer files by the large-enterprise unit; and strengthened and computerized the VAT administration, and improved follow-up on delinuluent taxpayers. 


\section{JV. The FisancLal Sector}

35. The tinancial sector in Mali consists of (a) nine banks, comprising seven commercial banks, one agricultural bank and one housing bank; (b) three nonbank financial institutions (NBFIs), ${ }^{x}$ (c) two pension funds, comprising a social security fund for private sector employees (Irst itut National de Prévoyance Sociale, INPS) and a pension fund for civil servants (Caisse de Retraite de Mali, CRM); (d) five insurance companies; and (e) forty-six approved microfinance instilutions and a large number of informal microfinance institutions, funded mainly by foreign donors or nongovernmental organizations.

\section{A. Banking Sector}

36. Commercial banks and nonbank financial institutions are governed by the banking law of BCEAO and supervised by the Commission Bancaire, which are both established as regional institutions." The BCEAO has also issued regulations for microfinance institutions, while the insurance companies are regulated and supervised at the regional level by the Conférence Inter-Africaine du Marché des Assurances (CIMA).

37. The banking sector has played an important role in supporting Mali's economic devclopment, as evidenced by the increasing monetization of the economy and the deepening of financial intermediation. The ratio of bank deposits to GLP increased frum about $5 \frac{1}{2}$ percent in 1980 to about $12 \frac{1}{2}$ percent in 1990 and 15 percent in 2000 , while the ratio of credit to the economy to GDP has increased since the mid-1990s, although from very low levels (Table IV.1).

\footnotetext{
${ }^{7}$ They are the following: Banque de Développement du Mali (BDM-SA), Banque Internationale pour le Mali (BIM-SA), Banque Malienne de Crédit et de Dépôts (BMCD), Bank of A frica (BOA-MALI), Banque Commerciale du Sahel (BCS), Banque Internationale pour le Conmerce et l'Industrie au Mali,(BICI-M), Ecobank-Mali (ECB-M), Banque Nationale de Développement Agricole (BNDA), and Banque de l'Habitat du Mali (BHM).

They are (a) a specialized credit institution for small and nedium-sized enterprises (Crédit Iniliative du Mali, CI-SA) and two (b) leasing companies (Equibail and Société Malienne de Financement, SOMAFI).

${ }^{9}$ The regional banking commission, commission bancaire, is based in Abidjan (Côte d'Ivoire) and was established in October 1990. The commission conducts on-site inspections and off-site analyses of monthly statistics of all registered banks and tinancial institutions in the WAMU.
} 
Table IV.1: Mali: Key Indicators of Financial Intermediation, 1980-2000 (In percent of GDP, unless otherwise indicated)

\begin{tabular}{lrrrrrrrr}
\hline & 1980 & 1990 & 1995 & 1996 & 1997 & 1998 & 1999 & 2000 \\
\hline Crulit wo the economy & 20.3 & 12.5 & 10.8 & 13.1 & 14.1 & 16.0 & 17.5 & $\mathbf{1 6 . 4}$ \\
Moncy supply & 15.6 & 20.0 & 23.0 & 24.1 & 24.3 & 22.6 & 21.9 & 23.5 \\
Bank deposits & 5.4 & 12.4 & 14.3 & 14.9 & 15.1 & 14.1 & 14.5 & 15.0 \\
Currency in circulation/M2 & 64.6 & 34.7 & 37.9 & 38.0 & 37.5 & 37.6 & 33.9 & 36.3 \\
& & & & & & & & \\
\hline
\end{tabular}

Sources: Central Bank of African States (BCEAO); and Fund staff estimates

38. Despite the deepening of the financial sector, financial intermediation remains wcak, and bank services are concentrated in the urban areas. The underdeveloped financial in lrastructure is reflected in a high currency-to-deposit ratio (56.9 percent in 2000). The share of short-term credits remains large (about 711/2 percent in June 2001). Lending is mostly limiled to short-term trade finance, as banks are cautious about extending long-tcrm credits for investment because of the paucity of bankable projects, the high proportion of short-term deposits (about 59 perceril of total deposits in June 2001) and an inadequate legal and judiciary protcction against delinquent debtors.

39. Against the background of a continuing deterioration of the banking system in late 1980s, the government implemented reform measures aimed at restoring the financial viability of banks through recapitalization, the streamlining and modernization of operations, the improvement of management, and the strengthening of the collection of nonperforming loans. Almost ali the state-owned banks were restructured, and steps were taken to open equity to private shareholders, and to hire foreign management. As a result of the implementation of reform measures, the financial position of the banking systcm improved significantly, and most of the banks resumed normal activity and profitability.

40. The banking sector is still characterized by substantial government ownership. Of the nine banks, three (Bank of Africa - BOA-Mali; Banque Internationale pour le Commerce et I'Industrie en Mali - BICI-M; and Ecobank-Mali) are fully private. The government has a majority share in one bank and a minority share of at least 20 percent in four other banks, while onc bank has government participation of less than 20 percent. Details relating to the size, structure and ownership of Mali's banks are provided in Table 23 in the Statistical Appendix.

41. The Banque de Développement du Mali (BDM-SA) is the largest bank in terms of capital, deposits, and number of branches. The BIDM was restructured in $1988-89$, leading to the establishment of the BDM-SA in Iune 1989 as a mixed-capital company in which the government holds 20 percent of the shares. The government intends to withdraw from the BDM-SA by end-2004. Steps were taken to attract a foreign partner to the Banque Malienne de Crédit et de Dépots (BMCD). A consortium consisting of the BDM-SA and BMCE 
(Banque Marocaine du Commerce Extericur) holds a majority of the shares, and the BMCD has merged with the BLM-SA. ${ }^{16}$ The resulting combined bank will account for aboul 46 percent of the deposits in the banking sector and rank $7^{\text {th }}$ in size in the WAEMU. The Banque Internationale pour le Mali (BIM-SA), established after the bankruptcy of the Meridien-BIAO in 1995, is the second largest bank in terms of lending activity. The government intends to withdraw completely from the BIM-SA and open the bank to forcign participation in its capital and management by mid-2002. The privatization of the Banque Commerciale du Sahel is also planned for mid- 2002 .

42. The fragile economic environment, lack of qualified bank personnel, and weak legal and judicial framework pose risks. The ratio of nonpcrforming loans to total outstanding bank credit fell, however, from 28 percent at end-June 1998 to about 24 percent at endJune 2001, mainly owing to more efficient recovery actions and better risk assessment in extending new credits. The still high level of nonperforming loans is partly due to the carryover by the BDM-SA of a stock of bad loans from the liquidated bank (BDM).

43. Despitc recent improvements, some banks still face diffìculties in respecting some of the prudential ratios established by the regional banking commission, in particular the medium- and long-tern maturity-matching ratios and the portfolio structure ratio. The situation regarding the observance of the prudential ratios is summarized in Table IV.2.

\section{B. Nonbank Financial Institutions}

44. The social security finds are characterized by weak management, insuflicient controls, inadequate accounting, and expenditures that exceed revenues. According to a World Bank study the CRM requires subsidies from the budget of at least 0.1 percent of GDP per year. The financial situation of the INPS, even if not as dramatic, is also wcak. Audits of the pension funds (CRM and INPS) have been prepared and an action plan, agreed with the World Bank, was issucd in December 2000; it is currently being implemented. 'This will lead to better transparency in the instilutions' financial condition, which is necessary for the preparation of the actuarial study. The govemment is taking preliminary steps to prepare an action plan based on a comprehensive review of both institutions.

\section{Microfinance}

45. Microfinance institutions include a variety of savings and credit institutions that are differentiated from commercial banks by sizc, structure, objectives, and technical and financial capacity. The sector encompass (a) mutual savings and loans institutions (institutions mutualistes), governed by their members and whose main activity is savings mobilization; (b) autonomous village banks (caisses villagoises d epargne ef de crédit autogérées, CVECA), governed by the villages; and (c) direct credit institutions (institutions de crédit soliduire), whose main activity is to provide credit to small borrowers.

117) The merger became official November 2, 2001. 
Table IV.2. Mali: Prudential Regulation Situation, December 2000 - June $2001^{1}$

\begin{tabular}{|c|c|c|c|}
\hline \multirow[b]{2}{*}{ Prudential Rule } & \multicolumn{3}{|c|}{ Number of Financial Institutions Not Mecting Requirements } \\
\hline & Deccmber 2000 & March 2001 & June 2001 \\
\hline Minimurn capital requirement ${ }^{2}$ & $\mathbf{l}$ & 2 & 2 \\
\hline Capital adequacy ratio ${ }^{3}$ & 1 & 4 & 3 \\
\hline Liquidity ratio (applicable only to banks) & 4 & 5 & 6 \\
\hline Division of risk ${ }^{5}$ & 3 & 2 & 0 \\
\hline Medium- and long-term maturity matching & 6 & 6 & 6 \\
\hline Off-balance sheet fixed asssets ${ }^{7}$ & 0 & 0 & 0 \\
\hline Ratio of fixed assets and equity ${ }^{8}$ & 1 & 0 & 1 \\
\hline Insider lending" & 1 & 1 & 2 \\
\hline
\end{tabular}

\footnotetext{
${ }^{1}$ The data cover nine banks and three nonbank financial institutions (NBFIs).

2 Minimum capital requirement is CFAF 1 billion for a commcrcial bank and CFAF 300 million for an NBFI.

${ }^{3}$ The minimum requirement for capital adequacy ratio was increased from 4 percent to 8 percent in January 2000 , but a two-year transition period for meeting the ratio was granted.

${ }^{4}$ The rinimum requirement for the liquidity ratio (ratio of liquid assets to slort-tern liabilities) is 75 percent.

- The limit for loans representing more than 25 percent of the capital base is eight times the capital base.

- The minimum coverage of medium- and long-term liabilitics by mcdium- and long-term assets is 75 percent.

${ }^{7}$ The maximum ratio of off-bnlance-sheet fixed assets is 15 percent.

${ }^{8}$ The maximum ratio of fixed assets and ecpuity investerent to capital is 100 percent.

The maxiınum requirement for insider lending is 20 percent of total lending.
}

46. Microfinance institutions have emerged in Mali since the mid-1980s to mobilize smiall savings and linance microprojects in the informal sector in both urban and rural areas, showing a preference for low-income groups and individuals. Microfinance activities have grown rapidly in recent years. At present, there arc 342 such institutions in Mali, with a total membcrship of 405,751 individuals, compared with 313 institutions and 346,093 individuals in 1999. At end-2000, total savings collected by these instilutions amounted to about CFAF 14 billion (an increase of $211 / 2$ percent over the previous year), while total loans amounted to CFAF 16.0 billion (a 1.7 percent increase compared with end-1999). Total savings represented about 5 percent of deposits in the banking system, while total loans amounted to about $5 \%$ percent of the credit to the economy granted by the banking system. The gap in resources was financed by borrowing from the banking sector and external resources. The overall performance of microfinance institutions is satisfactory, with a credit recovery rate of more than 90 percent, except in lew cases, and an average ratio of nonpcrforming loans to total loans of 7.0 percent.

47. The oversight responsibility for microtinance opcrations is undertaken by the Ministry of Finance, which approves, delivers, and withdraws the licenses of microfinance institutions, and controls and supervises them. The BCEAO is mainly responsible for the control and surveillance of umbrclla organizations of microtinance institutions, and, in conperation with the regional banking commission, it defines prudential ratios. The commission conducts surveillance opcrations and proposes disciplinary sanctions when microfinance institutions do nol observe regulations. Following the adoption of the PARMEC (Yroject d'Appui à la Règlementation des Mutuelles d'Epargne et de Crédit) law 
by the WAMU in December 1994 (and its application decree in August 1995), microfinance institutions are required to register at the Ministry of Finance. The law and its implementation decree specify requirements for constituting institutions, including thcir administrative structure, prudential ratios to be met, and penalties. ${ }^{11}$

48. By mid-2001, 46 microfinance institutions had received formal approval for their operations. The government intends to assist the further expansion of the sector on the basis of an action plan. Policies are aimed at bringing the microfinance institutions into full compliance with the laws and regulations governing their activity, providing training in management and accounting, fostering coopcration between formal commercial banks and the microfinance system, and creating a national fund for microfinance.

49. The government launched in 2000 a financial sector development project, with the assistance of the World Bank, to consolidate the gains obtained so far. The main objcctivc of the project is to improve the soundness, performance, and competitiveness of the tinancial sector by (a) restructuring and privatizing viable state-owned banks; (b) strengthening the Ministry of Economy and Finance to enable it to better follow up on the rccommendations of the supervisory authorities; (c) strengthening nonbank and microfinance institutions; and (d) improving the legal and regulatory environment affecting the financial scetor through adequate implementation of business laws and regulations enacted at the regional level by OHADA (Organisation pour l'Harmonisation du Droit des Affaires en Afrique). ${ }^{\text {?2 }}$

\footnotetext{
${ }^{11}$ The implementation decree specifies (a) a cciling of 5 percent on operations other than savings and credits; (b) minimum reserves ( 15 percent for mutual savings and loans institutions, 30 percent for autonomous village banks, and 40 percent for direct credil institutions); (c) a ratio of medium- and long-term loans to capital and reserves below 100 percent; (d) a ceiling on the total amount of loans granted to anyone holding a management position in the institution (under 20 percent of the value of the same individual's deposits); (e) a ceiling on the total amount of loans granted to a single individual (under 10 percent of the total value of deposits); and (f) a ratio of liquid assets to short-term liabilitics of at least 80 percent.

12 The following texts have been adopted by the Council of Ministers of Justice and Finance, which is the legislative body of OHADA: (a) General Commcrcial Law; (b) Corporate Law and rules concerning different types of joint ventures; (c) laws concerning secured transactions such as guarantees and colliterals; (d) Debt Recovery and Enforcement Law; (c) Bankruptcy Law; (f) Arbitration Law; and (g) Accounting Law, The OIIADA legislation is applicable in Benin, Guinea-Bissau, Burkina Faso, Camcroon, Central Africa, Chad, Comoros, Congo, Côte d'Ivoire, Equatorial Guinea, Gabon, Guinea, Mali, Niger, Sencgal, and Togo.
} 


\section{Trade Regime}

50. Mali shares a common trade regime with other members of the WAEMU. The common external tariff (CET), with four tariff rates $(0,5,10$ and 20 pereent $)$ was adopted in January 1,2000 , together with a uniform statistical duty of 1 percent. $\Lambda$ the same time, the custom union dismatiled internal tariff barriers and adopted common rules for custom valuation of goods and common safeguards measures. Mali is compliant with the tariff rate structure of the union and has effectively implemented the dismantling of internal tariffs. ${ }^{13}$ The country is broadly in compliance with the common nomenclature. Imports to Mali are not subject to quantitative restrictions (Box 5.1).

51. Mali does not provide additional protection to its economic activities through safeguard measures. Concerning common safeguard measures established by the WAEMU, Mali does not implement the decreasing protection tax (Taxe Dégressive de Protection, TLP) applied by some member countries to provide temporary and declining protection for selected jroducts, nor the compensatory import levies (Taxe Conjoncturelle à l'Importation, TCI). It only maintains a surtax of 25 percent on imports of wheat flour, while a 55 pcrcent surtax on sugar was removed in August 2001. ${ }^{14}$ While a common antidumping legislation for the WAEMU has still to be prepared, Mali does not implement antidumping tarifis unilaterally.

52. Given Mali's relatively open trade regime, the major remaining source of distortions is the large number of exemptions on import duties and VAT under existing import codes and special regimes. This is an issue that will require harmonization at the regional level. The WAEMU is preparing a common proposal on transaction valuation for negotiations with the WTO. Until the two inst itutions reach an understanding, the WAEMU member countries, including Mali, do not comply with the WTO standards on custom valuation.

53. Mali is a signatory of the Cotonou Convention. ${ }^{15}$ As a result, many Malian exports to the European Union enjoy non-rcciprocal preferential treatment in the form of exemption from import dutics. Malian goods enjoy non-reciprocal preferential access to the markets of developed countries other than the European Union member states under the generalized system of preferences. However, the scope of this preferential treatment is limited, owing to

${ }^{13}$ Eligible industrial products are those with a regional value added equal to at leasl 40 percent of total value added or with a regional content of at least 60 percent. All dutics on agricultural products and handicrafls were eliminated in July 1996.

14 The reintroduction of import protection for sugar would require the implementation of the TCI, based on the calculation of a trigger price.

${ }^{15}$ The convention regulates relations between the European Union and the African, Caribbean and Pacific ( $A C P$ ) countries in the arcas of trade cooperation and development aid. Mali ratiticd the Convention on April 19, 2001. 
the small number of products exported by the country. At the WAEMU level, Mali does not face formal legal or regulatory impediments to its cxports.

\section{Box V.1. WAEMU: Implententation of the Common External Tariff (CET)}

As of January, 1, 2000, the adoption of the CET resulted in

- a common classification of goods;

- the implementation of a common extemal tariff;

- the abolition of tarifls within the WALMU for local primary goods and eligible industrial products; and

- the adoption by member countries of conmon salizguartis.

The common classification of goods was adopted in mid-1998 for inplementation on January 1, 1999. Most member countries, however, expcrieneed some delays in effective implementation. In September 1999, the WAEMU Commission agreed to reclassify 20 products (mostly agricultural inputs and manufactured goods), mainly by creating subproduct categories corresponding to new tariff lines. In December 1999, the commission agreed to the reclassification of anotler 96 products.

The ad valorem CET has four rates applicable to the following broadly defined categories: "social" products (0 percent), "primary" products ( 5 percent), "intermediate" goods ( 10 Tercent) and "final consumption" goods (20 percent). In addition to the tariff, other taxes include a statistical duty of 1 percent on most inports, $\ddot{2}$ solidarity contribution (PCS) paid to the WAEMU institutions-equivalent to 1 percent of the value of goods imported from other countries outside the WACMU, excluding petroleum products and exemptcd imports.

As of January 1,2000, all tariffs within the WAEMU have been removed for local primary goods and eligible industrial products. For ineligible industrial products, there is a reduction of 5 percent on the tariff charged on equivalent goods imported from outside the region.

The common safeguards to help member coundies cope with the adjustment period include threc instruments: the decreasing protection tax (TDP); the compcnsatory import 1evy (TCl); and administratively set import values (valeurs de référence):

- The TDP is a temporary surtix of 10 percent or 20 percent applied on the c.i.t. value and linearly declining over four years (from July 1999 to December 2002) lor industrial aud agro-industrial products. The TDP and the TCI cun be applied cumulatively on the same product.

- The TCI is a 10 percent protection levy against fluctuations in international prices for agricultural products. It is applied when the intemational commodity price falls below the trigger price, calculated as a weighted average of the domestic production cost $(70$ percent) and international prices ( 30 perecnt). The trigger price is set and adjusted every six months by the WAEMU Commission, hased on developments in world market priccs. The 20 percent tax can be replaced by a special levy (pérequation) absorbing the difierence between the trigger price and the alctual import price.

- Finally, World Trade Organization (WTO)-compliant aderinistratively set ituport values could be assigned to a limited number of products; they will serve as the tax base for all customs taxes. However, these have not yet been implemented. 


\section{COTTON SECTOR: CRISIS AND REFORM}

\section{A. Backgraund}

54. Mali is sub-Saharan Africa's largest cotton producer. During 1989/90-1997/98, cotton production doubled in this West African nation 10 reach 523 thoustand tons. The rapid surge in production was mate possible primarily by increased land use and investment in new ginneries, and not by productivity improvements; in fact, seed cotton yield has been on a declining trend since the late 1980 s. The introduction of new, higher-quality varieties of seed cotton was also hclpful in raising production to some extent in the post devaluation period. Cotton production was further boosted by the devaluat ion of the CFA franc in 1994. In 1997/98, the cotton sector accounted for nearly half of export revenue, 9 percent of GDP, about 6 percent of government's total tax revenue. The cotton sector directly affects the livelihood of about a third of the Malian population (Figure Vl.1).

Figure VI.1 Mali: Cotton Production and Yield, 1981/82-2000/01

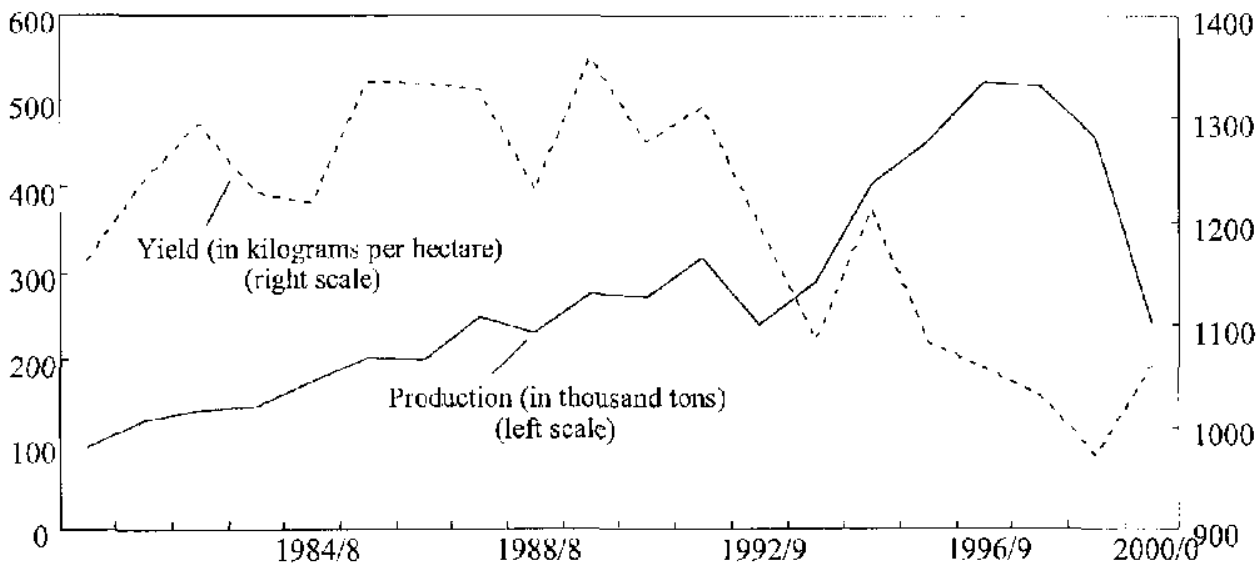

55. Morc recently, as explained below, the sector has cncountered difficulties, starting with the 1999/2000-crop year, when C.MDT was unable to pay an adequate producer price. In Junc 2001, a large number of cotton farmers boycotted production for the 2000/01 season in protest of the lew producer price offered by the CMDT. As a result, production fell by about 50 percent. However, as described below, the Malian authorities have cmbarked on a reform of the sector, which has helpcd to restorc producer confidence. 


\section{B. Organization of the Cotton Sector}

56. Mali's colton industry is organized as a vertically integrated system with the Compagnie Malienne pour le Developpement des Textiles (CMDT) at the center of all related activities. The CMDT is a vertically-integrated monopolist-monopsonist; it controls all aspects of the cotton sector in Mali, including: sale of seeds; purchasc of sced cotton; ginning: import, transportation, sale and distribution of fertilizer, pesticide, seed cotton, and cotton fỉber; crop financing; and marketing of cotton fiber. The Malian government owns 60 percent of its capital and the Compagnie Frunçaise pour le Developpement des Textiles (CFDT) owns the remaining 40 percent. Also, the CMDT provides training, extension services, and organizational support to cotton farmers, in addition to mobilizing and distributing credit.

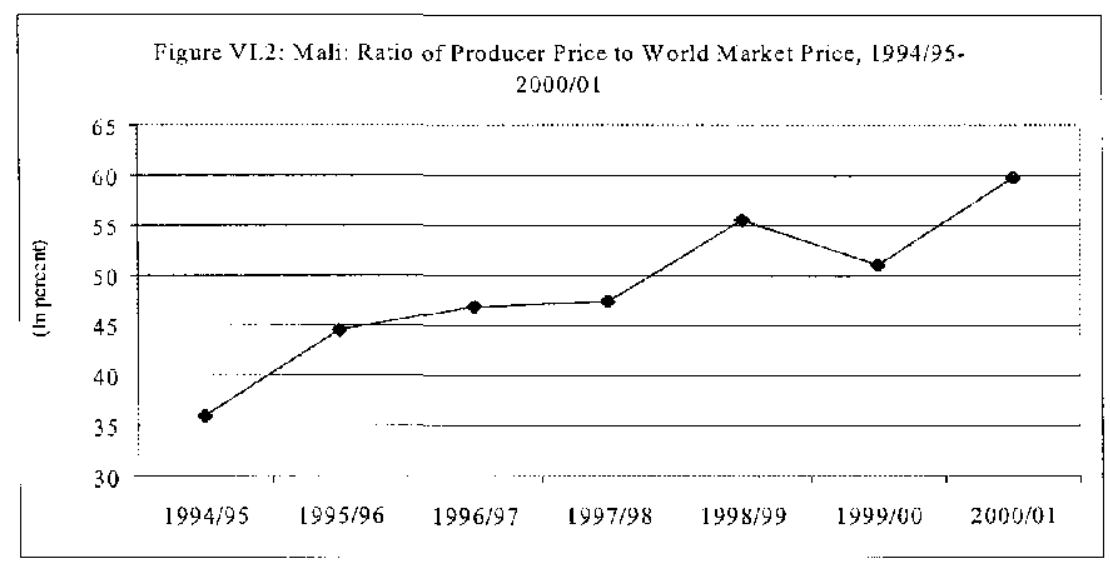

57. The sector's integrated monopsonistic structure generates a number of inefficiencies and rents. The implicit tax burden on cotton farmers has historically been heavy. For example, in 1994/95, Malian producer price (including benefits from CMDT's public services) was about 36 percent of world market price--compared with $70-80$ percent in India and Zimbabwe, where the production process is liberalized (Figure VI.2). However, progress has been made in raising the share of the producer price relative to the world price, with this ratio reaching 60 percent in $2000 / 01$.

\section{Background to the Crisis in $2000 / 01$}

58. In protest of the low producer price paid by the CMDT around May-June 2000 for the $2000 / 01$ scason, a large number of Malian cotton farmers boycotted production. At the beginning of the cotton season, CMDT had announced a price for cotton seed of CFAF 160 per kilogram, compared with CFAF 190-200 per kilogram in neighboring 
countries. By the time the government stepped in to resolve this problem, it was too late in the season to resume planting. ${ }^{16}$ In addition, poor rainfall compounded an already precarious situation. The liquidity crisis faced by the CMDT's had a number of dimensions:

\begin{tabular}{|c|c|c|c|c|c|c|c|}
\hline \multicolumn{8}{|c|}{$\begin{array}{l}\text { Tuble VI.1 Maii: Cottcn Prodtcerion, Cost, and Revenne. 199-1/95-2000'01 } \\
\text { (Ic cinis indicated) }\end{array}$} \\
\hline & $1994 / 45$ & $1995 / 56$ & $1596 / 97$ & $197 / 98$ & $: 998 / 59$ & 1599,00 & 200001 \\
\hline Prodlictioa cf seed cotton (I) ' & 293.0 & 405.9 & 452.1 & 522.9 & 518.1 & 455.5 & 242.7 \\
\hline Percent change & 21.8 & 33.5 & 11.4 & 15.7 & -9.9 & .11 .3 & $-47 . \hat{3}$ \\
\hline Proultiverua of fiters (2) ${ }^{1}$ & 128.] & 1693 & 185.6 & 217.7 & 217.1 & 197.3 & 101.9 \\
\hline Quantity exporss & $\cdots$ & $\ldots$ & $\ldots$ & 216.0 & 215.5 & $199 . ?$ & 100.3 \\
\hline Quartity sold locally & $\cdots$ & .. & $\ldots$ & 1.7 & 1.6 & 1.6 & 1.6 \\
\hline Fither yield $(3)=\{2, x(1)$ & 0.44 & 0.42 & 0.42 & 0.42 & 0.42 & 0.43 & 0.42 \\
\hline Psuduex price (4) ${ }^{4}$ & 120.0 & 155.0 & $15 \varsigma .0$ & 170.13 & $185.0^{\circ}$ & 150.0 & $170.1 \mathrm{j}$ \\
\hline Mimmun prix & 130.] & 155.0 & 155.0 & 140.3 & 145.0 & 150.0 & 130.0 \\
\hline Bonus & (a.j) & c. $(1$ & 0.11 & $30 . j$ & 40.0 & 0.0 & 0.j) \\
\hline Producer price in cotton jese equivalent $(S)=(4)(3)\}^{4}$ & 297.4 & 371.6 & 360.6 & 408.4 & 441.5 & 349,4 & $-0.5,1$ \\
\hline Luis prodectite cost (6) & $35: 4$ & $34 c .2$ & หว1.6 & 405,3 & 419.9 & $419.6 \mathrm{i}$ & 466.4 \\
\hline Total urit cost of extcn Jber $(7)=(5) \cdot(6)$ & 653.8 & 711.8 & 7.11 .2 & 813.6 & 852.3 & 769.0 & B71.8 \\
\hline Average saie price of cotton tiher $(9)^{4}$ & $32 x .9$ & 931.1 & 879.8 & y25.1j & 804.5 & 692.4 & 582.5 \\
\hline Toral revenue from cotton filer (in billion CFA franss) & $119 . \mathrm{C}$ & 157.6 & 166.8 & 203,2 & 177.5 & $1 \cdot 10.4$ & 71.5 \\
\hline l'otal cost on cottan tiber (in bullion CHA (iraulia) & 83.7 & 120.5 & 140.5 & 177.1 & J85.1 & 151.7 & 88.8 \\
\hline Gress CMDT profit (in 'jil. CF A farics) & 35.2 & 37.1 & 26.3 & 26.1 & -7.5 & -11.3 & $-17,3$ \\
\hline Tuxes and ather governmerd revenue (in billion (YA trancs) & 19,8 & (J.3 & 9.2 & $: 3.2$ & 1.3 & u.1 & 0.0 \\
\hline Averuge tax ${ }^{4}$ & $1: 5.9$ & 66.6 & 50.3 & 60.5 & 6.0 & 0.3 & 0.0 \\
\hline \multicolumn{8}{|l|}{ Mencrandum items: } \\
\hline \multicolumn{8}{|l|}{ Share ci Tevenule te procucers } \\
\hline 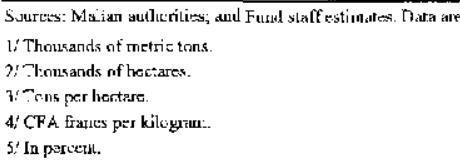 & in CMDT's & filancial ye & ear, netnol- & Fer in Septer & remler. & & \\
\hline
\end{tabular}

- World market price for cotton plummeted by about 30 percent during the period 1994/95-1998/99 (in CFA franc terms). In view of the secular price decline in world price during this periol, the minimum guaranteed producer price was adjusted downward starting in 1997/98; producers reacted by lowering production. Owing to the decline in

\footnotetext{
"Mcasures taken to resolve the situation and relieve farmers' financial burden include (1) an increase of the producer price by C.FAF 10 per kilogritril; (2) compensation to farmers for loss due to past lloods; and (3) rescheduling of farmers' loans over a period of $1-5$ years.
} 
cotion volume and export price, CMDT's revenue declined significantly during 199899-2000/01. This aggravatcd the company's liquidity position.

- The CMDT's liquidity problems were compounded by two factors. First, the company was unable to lower unit production costs, owing to operational inefficiencies, governance problems, and poor investment decisions. Second, CMDT's marketing strategies were weak. Mali's cotton fiber-which is generally viewed by industry analysts as being of good quality - was typically sold to one foreign marketing agency at substantial discounts which (according to recent studies done) were not justified by product quality.

- Reeling from its liquidity crisis, the CMDI announced a low producer price at the outset of the $2000 / 01$ season. A large number of farmers decided that they would boycott cotton production, unless their demands for a price increase were met. Negotiations involving the government. CMDT, and producers cventually resulted in a agreement that met the farmers' demands. It was signed in July 2000 , but by this time it was too late in the rainy scason for many farmers to rcsume planting. Consequently, cotton production declined by close to 50 percent in $2000 / 01$.

\section{Cotton Sector Reform}

59. Until recently, the implementation of reform in the cotton sector had been sluggish. The reform package - in the context of a new ESAF arrangement approved in mid-1999was based on the 1998 technical audit of the CMDT and called for (1) realization of substantial savings in procurement policy and procedures, and the management of the CMDT, particularly with respect to contracting procedures, stock management and overhead costs; (2) improving CMI)T's financial management and information systems, especially in accounting and management control systems; (3) improving ginning opcrations and maintenance policy of CMDT's factories so as to increase capacity utilization;

(4) cstablishing a marketing department within the CMDT and revising its fiber marketing policy; (5) undertaking annual financial and management audits of the CMDT and of the Cotton Sector Stabilization Fund by an external auditing firm; (6) strengthening of farmers; organizations and defining the modalities for producers' participation in the capital of the CMDT, with clearly defined exit strategy; (7) improving salcs pricing of cotton seed an derived products on the basis of an in-depth study of the cotton seed market; and (8) increasing private sector participation in transport and road maintenance activities. However, the implementation of these reforms encountered setbacks. With a view to reviving the reform process, the PRGF-supported program called for the authorities to adopt by end-September 2000 of a set of measures to improve transparency and efficiency of CMDT's financial management and reduce its production costs, based on the conclusion and recommendations of the financial audit completed in July 2000 . The reform measures that were proposed by the authoritics wcre reinforced with the help of the World Bank and the French authorities in the first hall of 2001. 
60. In order to build a broad consensus on the need for the reform of the cotton scetor, the government organized a participatory forum of major players in April 2001. Producers asked for the establishment of a pricing mechanism for seed cotton based on movernents in international prices. They also indicated that, as a way to lower its production costs, the CMDT should focus on its corc activities (ginning and marketing), entailing the transfer to the privatc sector, producer organizations, and decentralized conmunities of the company's noncore activities (transportation of seed cotton; distribution of fertilizer, pesticides, and farm equipment; and public services, such as road maintenance and extension services). $\Lambda$ small group of producers recommended the establishment of an independent entity to be managed and operated by the private sector in the OHVN (Office de la Ilaule Vallée du Niger) zone.

61. The governmerle's letter of development policy for the liberalization of the cotton sector was approved by the Council of Ministers in June $2001 .{ }^{17}$ The reform plan envisages the full liberalization of the cotton sector by 2005 . In the interim, measures will be taken to restructure the CMDT and make it more cost-cffective, refocus the CMDT's opcration on its core activities, establish a pricing mechanism for seed cotton based on market conditions, privatize the ginneries in one cotton-producing region, and prepare the sector for full liberalization. The authorities prepared a crisis resolution plan for the CMDT with technical assistance from the World Bank. An important feature of this plan was the full repayment by the CMDT of the CF $\Lambda F 30$ billion to the domestic banking system by September 2001. This was regarded as key to safeguarding the soundness of the banking systerm and ensuring the financing of the $200 \mathrm{~L} / 02$ growing season. In addition, in order to reestablish producers' confidence in the cotton sector and provide incentives for farmers to resume production, the government announced a price of CFAF 200 per kilogram for seed cotton following the participatory torum.

62. The reform of the cotton sector has the following main objectives:

a. to lower production cost;

b. to establish a market-based pricing mechanism based on free negotiations among economic agents;

c. to strengthen producers' organizations so that they can play a more important role in the management of the sector;

d. to cnhanec participation of the private sector, producers, and local government agencies in the development of the sector; and

e. to increase the contribution of the cotton sector to the national economy, thereby helping the fight against poverty and improving the standard of living of the population.

\footnotetext{
${ }^{17}$ The authorities worked in close collaboration with the World Bank in preparing the letter of development policy, following the participatory forum. The letter of development policy provides the objectives of the reform and a broad outline of the reform plan.
} 
63. To reach these objectives, the strategy adopted by the government is bused on the following main components: (i) refocusing the CMITT's operations on ginning and marketing, its core activities linked to the cotton sector; and (ii) completing the liberalization of the sector in the medium term. The refocusing of the company on its core activities will entail notably the withdrawal of the CMDT from the provision of extension services; its progressive withdrawal from its public service activities (the responsibility to provide inputs and equipment, and transportation); and a subsequent sealing down of the size of the company. Moreover, the government realfirms its commitment to follow a policy of liberalizing the economy and to foster a broader involvement of producers in the management of the sector, in particular by opening up the capital of the CMDT to producers and employecs; the government also reaffirms its commitment to strengthen participation of producers in the provision of the services they reed (such as advice on rural development, and the supply of imputs, equipment, and transpottation services).

64. In the short-run (2001-02), the key actions are to (i) prepare and implement a financial restructuring plan for the CMDT; (ii) initiate a program to refocus the CMDT on its core activities in the cotton sector; (iii) implement measures that have been identified to strengthen producers' managerial and organizational capabilitics; (iv) prepare a study for an autonomous region and complete the terms of reference for the opening up of the Office de la Haute Vallée du Niger (OHVN) region (which will eventually be cnlarged to incorporate adjacent areas) to a private sector enterprise; (v) prepare a study of the steps and options for the complete liberalization of the cotton sector over time; (vi) adopt and implement a mechanism for the determination of the producer price for seed cotton that reflects movements in international prices and takes into account prices offered in the sub-region; (vii) complete a study of the modalities for the transfer of extension services: and (viii) implementation by the CMDT of a more competitive mechanism for marketing colton fiber for export, namely, one that maximizes receipts. In addition, an institutional reform of the cottonseed oil subsector is to be implemented by June 2002 at the latest, with the liberalization of the sale price for collonseed. The cottonsecd oil public enterprise, HLICOMA, will be privatized by Junc 2002 at the latest. Over the medium term (2003-05), the conclusions and recommendations of the study referred to in point ( $v$ ) above will be validated and implemented in order to complete the liberalization of the cotton scctor by opening up the sector to compctition and by privatizing the CMDT.

65. The short-term aspects of the reform plan are being implemented as envisaged. The plan for the repayment of the CFAF 30 billion owed by the CMIT to local banks and guaranteed by the government was implemented before end-September 2001 , according to plan. The CMDT has begun implementing a set of measures to strengthen the transparcncy and effectiveness of its financial management and to reduce production costs. The company has begun to obscrve the effect of these measures on its production costs. In 2000 , the CMDT reduccd its production costs by about CFNF 15 billion, two-lhirds of which on a permanent basis. The CMDT has started implementing measures to improve internd management and marketing strategies, as well as lower its operating cost: (i) the president of the company was replaced last year; (ii) the wage bill has been cut by about 20 percent; (iii) the marketing of cotton fiber is no longer being done by one exclusive agent; (iv) all aspects of transportation 
have been liberalized, with the exception of that for seed colton, which is also slated for liberalization; and (v) investment in new capacity has been significantly curtailed.

Furthermore, the Malian authorities have discussed the letter of development policy for the cotton sector with the key players in the sector, and the document has been translated into local languages in order to ensure that it reaches as many cotton producers as possible.

66. There is evidence that the salisfactory implementation of the reform plan to date has restored confidence among colton growers. Crop surveys indicate that colton production will more than double in 2001/02, reflecting a boost in cotton growers' confidence following the significant increase in producer price and the good rainfall. ${ }^{18}$ The combined rolume and producer price hike in 2001/02 should raise cotton producers' income significantly in $2001 / 02$, thus contributing to a pickup in consurmption. 'Jhe authorities intend to launch public campaigns to build support around the objective of complete liberalization of the sector.

\section{THE GOLD SECTOR ${ }^{19}$}

67. Since the introduction of a new Mining Code in September 1991, broadly reflecting internationally accepted standards, and the arrival of a democratically elected government in 1992, the gold mining industry in Mali has grown rapidly. Following the commissioning of the Sadiola Hill mine in 1997, gold became Mali's second most important export commodity, after cotton. Currently, gold is mined at Sadiola Hill and Syama (industrial operations) and in the Kenieba and Kangaba regions. Gold represents Mali's most important mineral resource, with estimates of reserves ranging between 500 and 700 metric tons. ${ }^{20}$ Deposits of other mineral resources exist throughout Mali but remain largely undeveloped or of limited commercial significance. ${ }^{21}$

${ }^{18}$ This increase represents a technical rebound in production following the crisis in the cotton sector last year when production had declined by half.

19 This Chapter updates the overview of the gold sector provided in SM/00/189 (8/11/2000).

${ }^{20}$ Metric weights and measures arc used throughout this note, with the exception of costs and prices, which are conventionally cited in U.S. dollars per troy ounce. For ease of exposition, all references to tons should be interpreted as meaning "metric tons." A metric ton contains 32,150 troy ounces.

${ }^{21}$ According to the World Bank, Mali has significant geological potential. In addition to gold deposits, Malian geological structures are favorable for deposits of diamonds, base metals, phosphates, manganese, and uranium. Some fossil fuel deposits have been identified, as have significant reserves of bauxite, but these remain undeveloped, in part owing to the distanccs from mirkeis and insufficient transportation infrastructure. A small phosphate mine operated in Mali for scveral years prior to its closure in 1999. 


\section{A. Gold Mining}

68. Artisanal mining currently serves as a source of livelihood for an estimated 15,000 seasonal miners, a signilicant number of whom are women. Fstimates of artisanal mining has been constant over the period 1995-2000 at around $2 \frac{1}{2}$ tons for a value estimated at about CFAF 9 $1 / 2$ billion in 1999 (approximately $1 / 2$ of 1 percent of GDP).

Figure VII.I Mali: Gold Production, 1990-2000

(In metric tons)

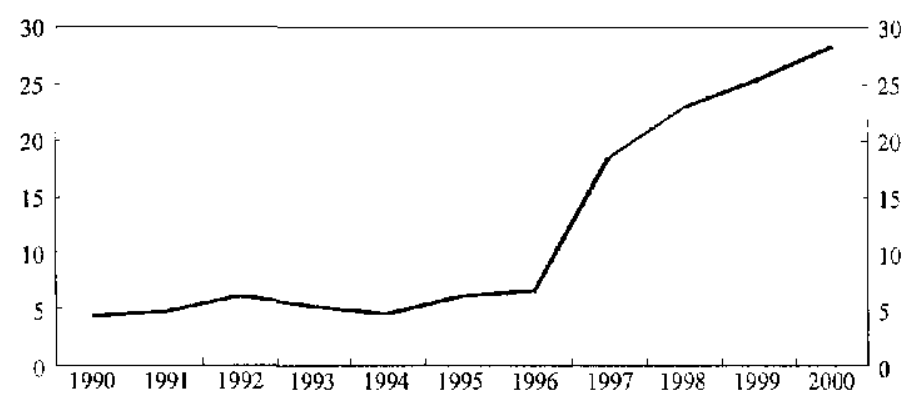

Source: Maiian authoritics.

69. Mali's first privately operated industrial gold mine was commissioned in 1990 at Syama in southern Mali. The Syama mine ${ }^{22}$ was originally developed by BIIP-Utah (Broken Hill Proprietary Company, Australia). Hampered by technical production difficultics and low profitability for several years, BHP-Utah sold its participation in the mine to Randgold Resources (South Africa) in 1996. Subsequent to laking over the Syama mine, Randgold undertook a new investment program aimed at reducing operating costs through increased throughput. This program has resulted in a reduction of production costs to about US\$210 per ounce, thereby returning the mine to profitability at current international gold prices (the London gold fix averaged US $\$ 279$ per ounce in 1999 and 2000 , and about US $\$ 265$ per ounce in 2001. Production rose to 6.1 tons in the Syama mine in 1999, an increase of some 56 percent over the average of 4 tons produced during 1993-98. In 2000, its production declined to 5.7 tons, and the Syama mine continued to encounter operating difficultics, which, combined with a declinc in international price caused the mine to cease operation in 2001.

${ }^{22}$ Owned by La Société des Mines d'Or de Syama SA (SOMISY). Participation in the capital of SOMISY at end- 1999 was as follows: Randgold Resources (South Africa), 75 percent; the government of Mali, 20 percent; and the International Finance Corporation (IFC), 5 percent. 
70. Mali's current largest gold mining opcration is the Sadiola minc, ${ }^{23}$ which has been opcrated by Anglo-American (South Africa) since its commissioning in early 1997. Sadiola is also reported to be the second-largest gold mine in West Africa, Production, all of which is cxported, has increased from $12 \frac{1 / 4}{4}$ tons in 1997 , the initial year of operations, to $153 / 4$ tons in 1998,17 tons in 1999 and 2000 and 20 tons in 2001 . On the basis of the original public estimales of reserves, the mine was cxpected to produce a minimum of 10 tons annually for approximately 13 years. The ores mined at Sadiola are relatively concentrated, yiclding estimated costs of production over the 1997-99 period of US $\$ 125-165$ per ounce, thus making the mine quite protitable.

71. The gold-mining operations ${ }^{24}$ at the Morila site began in the last quarter of 2000 with a production of 3.8 tons that year. The estimates for 2001 at 24.4 tons would make Morilla the largest minc in Mali (ahead of Sadiola). This mine was originally expected to produce some 7 to 10 tons of gold annually over an expected life of approximately 14 years. Average operaling costs are expected to be about US $\$ 137$ per ounce over the life of the project, well below current world market prices, virtually ensuring that the project remains economically viable even in the event of a significant world price decline.

72. AngloGold (South Africa) and lamgold (Canada) have recently developed a mine at the Yatela deposit, which started its operations and produced an estimaled 5.3 tons of gold in 2001. Production costs in Yatela are comparable to that of Sadiola, which make it quitc profitable. This mine is located about 25 kilometers from Sadiola, and plans call for the Sadiola refining facilities to process ores mined at Yatela. Based on reserves estimated at about 80 tons, the mine will have an estimated life of about 12 years, assuming an annual production rate of about $6 \frac{1 / 2}{2}$ tons.

\section{B. Potential Gold Mining Developments and Mineral Exploration}

73. The Malian mining company SODNNAF is reportedly developing an open cast gold mine in the Kodicran concession, which is expected to yield 3-5 tons of gold per year for approximatcly eight years. The Malian government is also actively sceking to privatize the

\footnotetext{
${ }^{23}$ Owned by I a Société d'Exploitation des Mines d'Or de Sadiola SA (SEMOS). Participation in the capital of SEMOS at end-1999 was as follows: Anglo-American (South Africa), 38 percent; lamgold (Canada), 38 percent; the government of Mali, 18 percent; and the International Finance Corporation (IFC), 6 percent.
}

${ }^{24}$ Owned by I a Société d'Exploitation des Mines d'Or de Morila SA (SEMOM). Participation in the capital of SEMOM at end-1999 was as follows: Randgold Resuurces (South $A$ frica), 80 percent; and the government of Mali, 20 percent. In April 2000, Randgold Resources sold 50 percent of its participation to AngloGold, a subsidiary of Anglo- $A$ merican, which became the mine operator in mid-2000. 
Kalana mine, in light of foreign investor interest in redevelopment. ${ }^{25}$ Potential future developments include the following concessions, with cstimated reserves in tons noted in brackets: Loulo (70-80); Segala (50-60); and Kalana (20-25).

74. Based on the production capacities of the four existing gold mines, the two mines currently under construction, and conservative estimates for artisanal production, Mali has the potential to export about 30-40 tons of gold annually over the medium term. On the assumption of world gold prices remaining near US\$275 per ounce, this production level should be sufficient to maintain the value of gold exports in the range of CFAF 150210 billion per year (approximately LS\$240-340 million, based on mid-2000 exchange rates). Over the longer run, and on the basis of conservative reserve estimates alone (abstracting from cost, price, and other considerations), firms operating in Mali should be able to maintain or cxeec cxports of 20-25 tons of gold annually until 2020. Thus, on the basis of known and proven gold reserves, current policies, and the assumption that world gold prices will remain near their current levels, Mali can reasonably be expected to remain an important African gold exporter for some time to come.

75. Currently, mineral exploration activity in Mali is dominated by gold, but it also includes some exploration for diamonds, fossil tuels, and other minerals. In July 2000 , more than 50 domestic and foreign companies were exploring under close to 90 permits, compared with only 12 exploration permits in 1990 . However, it is unclear how many permits are actively being explored, as opposed to simply bcing held for spcculative purposcs. Worldwide gold exploration expenditures have dropped significantly sinec 1998, following the decline in the price of gold, and Mali, along with other A frican countries, has suffered some slowdown in active exploration.

\section{Sector Institutions}

76. Overall responsibility for the mining sector lies with the Ministere des Mines, de l'Energie, et de l'Eau, which developed and implemented mining policies initially through the Direction Nationale de la Géologie et des Mines (DNGM).

77. The ГNNGM is responsible for formulating most aspects of mining policy, ${ }^{26}$ regulation of the sector, and the granting of exploration and mining permits. It also acts as the manager of the government's participation in the financial capital of mining ventures. Finally, the DNGM is responsible for conducting Mali's geological survey.

\footnotetext{
${ }^{25}$ In 1995, mining rights to the Kalana property werc granted to Ashanti Goldficlds (Ghana); however, with no progress made in redevelopment, the concession wis not renewed in 1999, and the government is seeking new investors.

${ }^{20}$ Mining tax policy is jointly developed with the Ministry of Economy and Finance.
} 


\section{Legal and Mining Taxation Framework}

78. Since 1970, mining in Mali has been regulated by legislation. Supported by the World Bank, this legislation was significantly reformed in 1991 and modified again in late 1999. The revisions introduced in 1999 reduced the number of mining titles and streamlined the permit issuance process. The revisions also substantially altered the taxation regime applicable to mining by shifting the tax burden from inputs and production toward profits. Thus, the royalty on gold production was reduced from 6 pereent to 3 percent and customs duties were lowered, in line with the West African Economic and Monetary Union common cxternal tariff. The tax holidays on corporate income and import duties during the initial years of production were elininated and a dividend withholding tax applied. Regulations concerning government participation in the capital of the mining enterprises (back-in rights) were also modified. These policy changes were designed to foster the development of new gold deposils and, at the same time, increase government revenue from the sector.

79. Since 1991, Mali has made use of a model investment agreenent to accelerate the process of negotiating and awarding permits for mining exploration. The standard agreement serves as a point of departure for negotiations with foreign and private operators and lixes fiscal obligations such is income taxes, tax exemptions, depreciation allowances, and royalties. While actual mining agreements are negotiated and could vary substantially, key features of the current model agreement are as follows:

- Pernits. Exploration permits are issued by the Minister of Mines for a period of three years, with a 50 percent reduction on the surface area at the discretion of the holder at the end of the second year of the first tenure. Exploration permits are twice renewable for three-year periods over a certain area, which again are reduced by half each time. Mining permits are granted by decree for a maximum of 30 years, including renewals, to applicants with provable, bona fide ore bodies.

- Capital. Earnings are freely repatriated.

- Taxes. Mining ventures are subject to the 35 percent corporate income tax (the previous law provided a corporatc income tax holiday for the first five years of production). Depletion allowances are sel at $271 / 2$ percent of gross sales proceeds. Imports used for exploration arc taxed at a zero rate, while imports used for production are subject to normal duties (the 1991 code granted duty excmptions to cover the first threc years of production). Gold production attracts a 3 percent ad valorem tax (under the 1991 law, gold production attracted a 3 percent royalty and a 3 percent proctuction tax).

- Kights to government participation. The government's "back-in rigbts" were also modified in 1999. The government of Mali now reserves the right to participate as a shareholder in the capital of a mining company to the extent of a maximum carried interest of 10 percent, frec of financial obligations, but with the right to preferential dividends, and the option to acquire an additional 10 percent working interest through 
a contribution to the financial capital of the venture. Under the 1991 mining law, the government retained rights to a maximum 20 percent participation through a combination of a 15 percent carried interest and 5 percent working interest.

\section{E. Impact of Gold Mining on the Economy}

80. In 1984, the first year of operations at the Kalana mine, the mining sector accounted for an estimated 11/2 percent of Mali's GDP. In 1990, the first year of operation of the Syama mine and the final yeur of production at Kalann, gold mining accounted for just over 2 percent of GDP, and about 14 percent of total export receipts. During the period 1992 2000 , the share of gold mining in GDP more than doubled, from $2 \frac{1 / 4}{4}$ percent to 6.2 percent, and the value of gold exports rose from 16 percent of goods cxports to about 50 percent. This is expected to further increase in 2001 with the share of the mining sector to GDP reaching almost 11 percent of GDP and or and 68 percent of exports receipts. Tax receipts from the sector increased from $3 \frac{1}{2}$ percent of total government revenue in 1995 to $8 \frac{1}{2}$ percent by 2000 .

\section{POVERTY STRATEGY}

\section{A. Poverty Issues}

81. Mali, with a GNP per capita of US $\$ 250$ in 1998 , is among the ten least-developed countries in the world. Its social indicators are significantly weaker than the averages for subSaharan Africa (Table VIII.1). About two thirds of the population in Mali live below the poverty line, with about onc-fifth living in extreme poverty. The majority of the poor live in rural areas. The government's current economic program, supported by the PRGF arrangement, reinforces the growth-oriented adjustment strategy in place since the early 1990 s that led to a boost in economic growth during the postdevaluation period (1995-2000), and contributed to a reduction in the incidenee of poverty by about $7 \frac{1}{2}$ percentage points between 1996 and 2000. Nonetheless poverty, remains widespread, given the extremely low per capita income base. 
Table Vill. 1. Mali: Basic Sucial ludicators for Mali and Sub-Saharan Africa

Population (millions, 19y)

Population growth rate (percent, 1998)

GNP per capita (US\$, 1998)

Illiteracy rate (percent, 1999)

Fomalc illiteracy rate (percent, 1099)

Gross primary enrollnent ratio (percent, 1998)

Of which: for girls (1998)

Infant mortality (per 1,000 live births, 1999)

Life expectancy at birth (years, 1999)

Access to safe watcr

(percent of population, 1998)

Sources: Work Bank, World Development Indicators, 2000: LNDP, Human

Development Report, 2001; and INESCO, Statistical Yearbook, 1999.

'Natural rate ol population growth as estimated in the 1998 census.

${ }^{2} 1997$.

\section{Box VIl.1. Mali: Poverty Data Issues}

Quantitative studies on poverty in Mali are based on two main survcys.

The first is the Budget Consumption Survey (BCS) for the year 1988/89, prepared with UNDP assistance. The first poverty profile for Mali was done using the BCS survey. The poverty line was then derived on the basis of the value of a typical bundle of goods ensuring a daily nutritional requirement of 2,450 calories.

The second survey is the 1994 Economic and Social Survey (EMCES), linanced by the World Bank. This survey was not designed for poverty analysis and therefore does not allow for an ensy' comparison with the BCS of the poverty status in Mali. The poverty line in this survey was derived by applying 1994 prices to the poverty line from the 1989 BCS. The sane methodology was applied to update the povcrty profile in 1996 and 1998. The fact the EMCES was conducted a few months after the devaluation (likely to reflect exceptional houschold bchavior) may have compromised the quality information on poverty in Mali.

The government launched a new BCS survey at the end of 2000 with final result expected in the first half of 2002 . This latest BCS is expected to provide significantly better information on the status of poverty in Mali, as well as on its causes. 
82. According to an evaluation madc by the Malian authorities, ${ }^{27}$ it was estimated that about two third of the population currently live below the poverty line, with poverty defined as being below the WHO-recommended level of daily caloric intakc. The primary finding of the three poverty surveys in Mali is that poverty increased from 1989 to 1996 both in rural and urban areas. This trend continued during the period 1994-96, immediately following the devaluation of the C.FA franc.

83. The 1998 and 1999 data, however, show a reversal in the trend, with poverty on the national level falling by $71 / 2$ percentage points between 1996 and 1999 . Poverty in Mali tends to be concentrated in rural areas, where shortages of food can become particularly acute during periods of drought. There are also sharp regional differences arising from different agro-ecological conditions. About 75 percent of the labor force resides in rural arcas, deriving its livelihood from cash crops (primarily cotton), food sops (millel, sorghum, maize, and rice), livestock herding, and other subsistence activities. Nomadic pastoralism is common in the north, and seasonal and permanent migration withir and outside Mali is widespread.

84. There have been significant advances in agricultural production in ccrtain areas over the past decade, although the impact of these advances on poverty has yet to be adcquatcly assessed. For example, Mali has recently become a leading producer and exporter of cotton fiber in sub-Saharan Africa, with production more than doubling since the devaluation of the CFA franc in 1994. Also, production of paddy rice in the Oflice du Niger zone

\begin{tabular}{|c|c|}
\hline \multicolumn{2}{|c|}{$\begin{array}{c}\text { Table VIII.2. Mali: Toverty Ilead } \\
\text { Connt, }\end{array}$} \\
\hline Year & lndex \\
\hline National & \\
1989 & 40.8 \\
1994 & 68.8 \\
1996 & 71.6 \\
1998 & 69.0 \\
1999 & 64.2 \\
Urban & \\
1989 & 15.0 \\
1994 & 26.6 \\
1996 & 40.6 \\
1998 & 36.3 \\
1999 & 31.2 \\
Rural & \\
1989 & 46.7 \\
1994 & 75.6 \\
1996 & 78.3 \\
1998 & 76.0 \\
1999 & 71.3 \\
\hline
\end{tabular}
has increased by a factor of five over the last 15 years. However, in spite of these positive developments, private investment in agriculture remains marginal.

85. The poverty gap is also much wider in the rural areas ( $451 / 2$ percent) than in the urban area (31.l percent), reflecting a higher concentration of social infrastructure in urban areas: especially in the district of Bamako. The surveys also show that poverty is higher among childrer and old pcople ( 71 percent) and in large households. Households where the head is a

${ }^{27}$ The Obscrvatoire du Développement Hunain Durable (ODHD) calculated poverty lines for 1996, 1998, and 1999. These have been based on the "rice equivalent" of the World Health Organization (WHO)-recommended level of calorie intake, combined with projections of the distribution of consumption in 1988-89, and adjusted for changes in prices and the level of GDP. 
farmer or stockbreeder, as opposed to being cmployed in the public or nonrural private sector, are poorer. The number of years of schooling of the head of the household was also found to be an important determinant of the level of poverty.

86. Notwithstanding the improvements over the last five years, Mali's key social indicators remain very weak by international standards. School enrollments have risen, but they remain low, and illiteracy remains extremely high, with pronounced gender and regional differences. In 1999, according to the UNDP's Human Development Report, only 40 percent of the total population over the age of 15 and only 33 percent of women were literate. In 1998, the gross primary school cnrollment rate (including Koranic, private, and community schools) was 50 percent for grades $1-6$ and 18 percent for grades $7-9$. The secondary school gross enrollment rate was only 5 percent, while the gross enrollment rate in higher education stood at 2 percent. Gender and regional difterences are reflected in lower cnrollment rates for poorer regions and tor girls. For example, Timbuktu and Mopti have gross primary enrollment rates of less than 30 percent, compared with 138 percent in Bamako, ${ }^{28}$ and primary enrollment of girls is roughly 25 percent below that of boys. The inability to recruit and train teachers in sufficient numbers has not only resulted in the deterioration of the quality of education and rising repetition and dropout rates, but have also limited the elimination of regional disparities. ${ }^{29}$

87. Midli's health indlicalors have improved over the last two decades, but they remain among the weakest in the world. Between 1988 and 1996, the crude death rate decreased from 22 to 16 per 1000 people, and infant mortality was reduced from 200 to 123 per 1000 live births between 1970 and 1996. Howcver, life expectancy at birth in 1999 was a mere 51 years, and maternal mortality was about 577 per 100,000 live births. ${ }^{30}$ As in most sub-Saharan $A$ frican countries, the main health problems are infectious and parasitic diseases, with malaria, measles, tetanus, acute respiratory infections, and diarrhea the leading causes of death. The prevalence of IIIV'AIDS in Mali is relatively low (about 2 percent of the population between 15 and 49 years old in 1999 according to the UNDP's Human Development Report) but rising, especially with seasonal migration to and from neighboring countries with high prevalence rates. Malnutrition is a scrious problem: in 1996, 30 percent of Malian children under 3 years of age were chronically malnourished, 23 percent suffered from acute malnutrition, and 40 percent were underweight.

${ }^{2 \times}$ The gross enrollment rate measures students of all ages in the numerator, including older children repeating the year. Net enrollment rates are based on students in the normative age group only. The net primary enrollment rates for Timbuktu and Bamako in 1998 were 24 percent and 100 percent, respectively.

${ }^{29}$ Data from the World Bank public expenditure review of education (1999), and ODHD reports (1996 and 1998).

40 Data from the demographic and health survey of $1995 / 96$ and the 1996 ODHD report, 
88. Access to health care is severely limited. In 1999 , only 36 percent of the population had access to a health facility within a 5-kilometcr radius, and many facilitics are poorly equipped and managed. There are wide disparities between regions and especially belween rural and urban areas. For example, in Mopti, one of the poorest regions, the infant/child mortality rate was double that in Bamako.

89. Access to water and adequate sanitation is also limited. In 2000, about 50 percent of the population had access to safe water, and only 8 percent had access to modern sanitary facilities. Rural villages typically rely on water from shallow wells, swamps, and creeks, which is often contaminated. In urban areas, access to safe waler and modern sanitation is higher but still considered initequate.

90. Gender inequality is quite pronounced in Mali. Women have limited access to productive resources and are generally not involved in public decision making. Gender incqualities tend to be reflected in high fertility rates, early pregrancies, and lack of access to education and health services. In rural areas, women have a heavy burden of agricultural work, and the lack of basic services adds considerably to the time they must spend on household chores.

91. According to the 1997 qualitative survey of perceptions ${ }^{31}$ of poverty in Mali, the nain perceived causes of poverty were natural disasters (drought and floods), a lack of access to fizctors of production and socioeconomic infrastructure, unemployment, and poor management of public funds.

\section{B. Policy Response}

92. With the establishment of a democratic government in 1992 and the resolution of the conflict in the north in 1994, substantial policy reforms have aimed at achieving sustainable economic growth and reduring poverty. To help alleviate the adverse effects of the devaluation of the CFA franc in early 1994, several poverty-targeted measures have been taken, including labor-intensive public works programs (AGETIPE), credit-based interventions, and a social safety net for vulnerable groups. The goverment's current cconomic program, which strengthers the growth-oriented adjustment strategy in place since the early 1990s, places increased emphasis on reinforcing the enabling environment for private scctor development. Effective implementation of the government's program led to an increase in economic growth during the period 1995-2000, which was a factor in reducing in the incidence of poverty between 1996 and 2000.

93. In addition to the benericial impact of growth on poverty reduction, the government is taking measures that will have a larger direct impact on poverty reduction, especially in rural

${ }^{31}$ Poverty was defined in terms of basic nceds deticiencies, with the following listed in order of priority: food, health, clothing, housing, support systems, tools and equipment for production, and employment. 
arcas, where the majority of the poor live. A number of sectoral programs have been or are being developed for health, education, food and nutrition, rural devclopment, water resources, the environment, and the promotion of women and children. However, policy formulation in these areas has been slow and implementation relatively weak, reflecting inadequate administrative capacity at the operational level.

94. The fiscal adjustment measures included in the government's program are designed to minimize any significant adverse cffects on the poor. The revenue mobilization effort will sustain the increase in poverty-related spending while allowing Mali to return to the path of fiscal consolidation. The program also enphasizes the reinforcement of public expenditure management, is particular for outlays to poverty reduction programs. These refonns, together with a decentralization of expenditure commitments and the placing of more emphasis on transparency and accountability, should increase cfficiency in the allocation and targeting of resources to the poor. Since poverty in Mali is predominantly rural, the key struclurial measurcs in the government's program are focused on measures to provide higher revenues to cotton firmers, through a comprehensive reform package aiming at a full liberalization of the cotton sector which affects the livelihood of one-third of the population.

95. During 1997-98, the government, employing widespread consultation and support from the UNDP, formulated its National Strategy for the Fight Against Poverty (SNLP), which was presented to a donor roundtable in September 1998. The SNLP was based on a number of studies on the characteristics and causes of poverty, using a large consultation process. The SNLP was published in July 1998. The preparation by the government of an interim PRSP (I-PRSP) in the sccond half of 2000 was an occasion to update the SNLP and provide it with an operational content.

96. The approach taken in the I-PRSP and in the preparation of the full PRSP has translated into higher cxpenditure directed to social sectors. The preparation of the I-PRSP and of the full PRSP has brought a ncw perspective to the government's poverty reduction policy, which is now oriented toward outcome and, therefore, loward improving the efficiency of resource use, is well as intersectnral budget allocation. Donor dependency, however, is high, which has tended to fragment government policymaking in the past, but efforts to improve donor coordination are ongoing as a result of the 1998-99 Organization for Economic Cooperation and Development (OECD)/Development Assistance Commiltee (DAC) Aid Revicw. 


\begin{tabular}{|c|c|c|c|c|c|c|}
\hline & 1995 & 1996 & 1997 & 1998 & 1999 & 2000 \\
\hline & \multicolumn{6}{|c|}{ (ln billions of CFA franes) } \\
\hline Pomary sector & $35 i 1.7$ & 344.5 & 360.6 & 3711.6 & $4(14.0)$ & 4245 \\
\hline Food crops & 159.9 & 142.3 & 148.9 & 141.5 & 164.3 & 195.9 \\
\hline Industrial crops I & 46.6 & 59.4 & 66.2 & 75.2 & 752 & 68.2 \\
\hline Livestock & 94.4 & 91.8 & 93.5 & 1000 & 104.7 & 109.2 \\
\hline Fisting & 10.0 & 10.1 & 10.2 & 10.4 & 10.5 & 10.7 \\
\hline Furestry & 33.8 & 40.8 & 41.8 & 43.0 & 44.3 & 45.5 \\
\hline Secondary sector & 116,3 & 122.6 & 151.1 & 160.9 & 164,3 & 177.2 \\
\hline Industry & 44.9 & 45.3 & 51.3 & 50.9 & 48.8 & 54.5 \\
\hline Mining & $: 4.7$ & 15.8 & $38 . \tilde{\mathrm{i}}$ & 46.4 & 50.9 & 56.5 \\
\hline | landierafts & $: 9.2$ & 20.7 & 20.4 & 21.0 & 21.3 & 20.1 \\
\hline Consiruction and puh ic works & 37.6 & 40.9 & 41.4 & $42 \%$ & 4.8 .8 & 460 \\
\hline Tertiary sector & 239.2 & 239.7 & 261.7 & 276.1 & 7.532 & 302.5 \\
\hline Transportation & 38.0 & 40.9 & 42.2 & 48.1 & 51.4 & 53.4 \\
\hline Trade & 104.6 & 118.3 & 118.9 & 123.8 & 136.5 & $14: 6$ \\
\hline Publiz administration & 50.4 & 52.4 & 52.5 & 54.2 & 53.2 & 54.0 \\
\hline Othęr services & 46.2 & 48.1 & 48.1 & sc. 0 & 52.1 & 53.5 \\
\hline GDP \{al factior cust\} & 706.2 & 726.8 & 773.4 & 807.0 & 862.0 & 900.2 \\
\hline Import akes & 40.4 & $5: 6$ & 57.3 & 64.8 & 68.6 & 64.6 \\
\hline \multirow[t]{2}{*}{ GDP (at market prices) } & 746.6 & 778.4 & 830.7 & 871.9 & 930.6 & 973.8 \\
\hline & \multicolumn{6}{|c|}{ (Annual percentage change Lnless atherwise indicated) } \\
\hline l'r:mary sector & 2.5 & -1.3 & 4.7 & 2.6 & 9.2 & 6.3 \\
\hline Foud crups & 11.9 & -11.0 & 4.6 & -5.0 & 197 & 15.7 \\
\hline Industrial crops & 18.7 & 27.5 & 11.4 & 13.5 & 0.1 & -9.4 \\
\hline Livestock. & -1.7 & -2.7 & 1.8 & 6.9 & 4.7 & 4.3 \\
\hline Fixhing & -0.8 & 1.2 & 1.2 & 1.6 & ..ú & 1.5 \\
\hline Forestry & 5.3 & 2.5 & 2.5 & 2.9 & 2.9 & 2.8 \\
\hline Secondary sector & 9.7 & 5.5 & 2.3 .2 & 6.5 & 2.4 & 7.5 \\
\hline industry & 10.5 & 0.9 & 13.3 & -0.8 & -4.1 & 11.7 \\
\hline Minirg & 0.8 & 7.8 & 140.8 & 21.9 & 9.8 & 11.1 \\
\hline Handicrafts & 7.0 & 7.6 & -1.3 & 2.8 & 1.6 & -5.6 \\
\hline Constrution and public works & 14.1 & 8.9 & 1.1 & 3.2 & 2.5 & 5.0 \\
\hline Tertiary sector & $1 . \mathrm{c}$ & 8.6 & is & 5.5 & 6.2 & 32 \\
\hline Trantsporlatijur & 6.6 & 7.5 & 3.3 & 139 & 6.9 & 3.4 \\
\hline Trade & $-1,3$ & 13.1 & 0.5 & 4.2 & 10.3 & 3.7 \\
\hline Public administration & 1.3 & 3.9 & 0.2 & 3.2 & -1.9 & 1.5 \\
\hline Other services & 1.5 & 4.2 & $-0 .:$ & 4.1 & 4.1 & 2.7 \\
\hline GDP (al tactor cost) & 5.6 & 2.9 & 6.4 & 4.3 & 6.8 & 5.5 \\
\hline Itroport taxes & 39.3 & 27.7 & 11.0 & 13.1 & 5.8 & -5.8 \\
\hline GIJP (al market priscs) & 7.0 & 4.3 & 6.7 & 4.9 & 6.7 & 4.6 \\
\hline \multicolumn{7}{|l|}{ Memorandım items: } \\
\hline GDP de:ator & 13.4 & 56 & 1.1 & 6.7 & -1.7 & 3.6 \\
\hline GDP at curresut murket prices ${ }^{2}$ & $1,186.8$ & $\because .31 \times 9$ & $1,423.5$ & 1.592 .5 & 1.670 .7 & 1.811 .2 \\
\hline
\end{tabular}

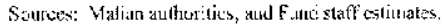

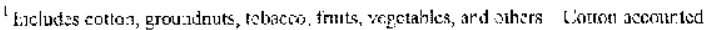

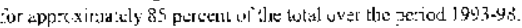

i $\ln$ billions or GIA lancs.

\section{(CInternational Monetary Fund. Not for Redistribution}


Table 2. Mali: Origin and Use of Resources, $1945-2000$

$\begin{array}{llllll}1995 & 1996 & 1997 & 1998 & 1979 & 2000\end{array}$

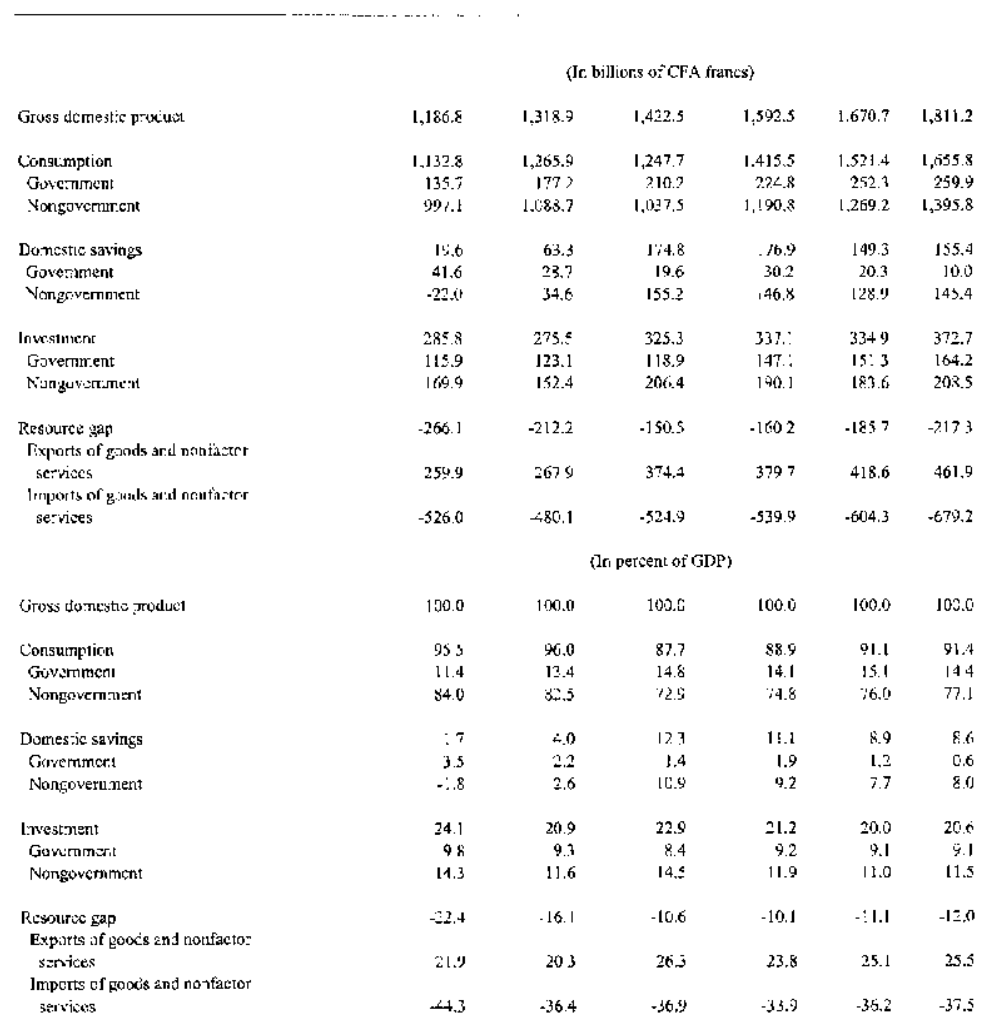

Nemorandum tems

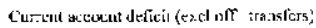
Of which: privare tuensfers

Of̂̃cial trar.stèrs

Net factor :normc

Nat:onal savengs

Current account defizit (ex:l.off, rransfers)

Of witis hrivat: transfers

iff:c:a: transfers

Vet factur incerne

Natiora. savings
(1) billions ef CFA francs)
$-230.3$

51.0

142.1

$\cdot 17.7$

197.6$$
\therefore 353 \quad-147
$$

$461 \quad 42.6$

$52.3 \quad 31 \mathrm{i}$

$-22.0 \quad-30.2$

1-2.1 221:

(Tr pertent af GDP)

$\begin{array}{rrrrrr}-i 9.4 & -14.1 & -95 & -5.3 & -108 & -120 \\ 4.3 & 3.5 & 3.0 & 2.5 & 2.7 & 2.6 \\ 12.0 & 4.0 & 2.2 & 1.7 & 1.4 & 20 \\ -1.5 & -1.7 & -2.1 & -1.9 & -2.6 & -3.8 \\ 16.7 & 10.5 & 15.5 & 11.7 & 10.7 & 1.1\end{array}$

Sources. Ma ian axtho:ticz; and find scaff cstimates. 
Table 3. Mali: Agricultural Production and Average

Producer Prices, 1995/96-2000/01 '

(In thousands of metric tons)

Production (gross)

\begin{tabular}{|c|c|c|c|c|c|c|}
\hline Cotron & 406 & 452 & 523 & 519 & 460 & 243 \\
\hline Groundruals & 157 & 134 & 143 & 151 & 158 & 160 \\
\hline Millet & 707 & 739 & 577 & 732 & 858 & 722 \\
\hline Sorghum & 710 & 541 & 503 & 539 & 641 & 533 \\
\hline Maize & 264 & 294 & 311 & 354 & 397 & 205 \\
\hline Paddy rice & 463 & 627 & 511 & 634 & 722 & 671 \\
\hline Average producer prices & \multicolumn{6}{|c|}{ (In CFA francs per kilogram) } \\
\hline Coftous, ${ }^{23}$ & 155 & 155 & 170 & 185 & 150 & 170 \\
\hline Fíoor price & 125 & 125 & 125 & 145 & 150 & 170 \\
\hline Rebate from profit sharing & 30 & 30 & 30 & 40 & 0 & 0 \\
\hline Groundmits & $1 \times 0$ & 249 & 150 & 152 & 159 & 159 \\
\hline Millet & 97 & 77 & 105 & 71 & 70 & 71 \\
\hline Sorghum & 99 & 77 & 98 & 86 & 84 & 86 \\
\hline Maizo & 83 & 69 & 80 & 67 & 66 & 67 \\
\hline Pauddy rice & 118 & 105 & 123 & 115 & 113 & 116 \\
\hline
\end{tabular}

Sources: Malian authorities; and Fuad staff estimates.

The crop year is April-Mareh; the markeling year is November/October.

2 Except for cotton, the marketting of agricultural products by official agencies was discontinuted in 1995.

3 Actual price for first-quality cotton. including rebate based on profic of the cotton company (CMDT). 
Table 4. Mali: Cereals - Cultivated Area and Rainfall, 1995/96-2000/01:

$\begin{array}{lllllll}1960-90 & 1995 / 96 & 1996 / 97 & 1997 / 98 & 1998 / 99 & 1999 / 00 & 2000 / 01\end{array}$

Average

Est.

(In thousands of hectares, unless otherwise indicated)

\begin{tabular}{|c|c|c|c|c|c|c|c|}
\hline Cultivated area & & & & & & & \\
\hline Millet/sorghum & 1,423 & 2,137 & 1,476 & 1,451 & 1,527 & 1,661 & 2,057 \\
\hline Deviation $^{2}$ & & 50 & 4 & 2 & 7 & 17 & 45 \\
\hline Maize & 97 & 205 & 181 & 197 & 239 & 419 & 172 \\
\hline Deviation $^{2}$ & & 111 & $8 ?$ & 103 & 139 & 332 & 77 \\
\hline Paddy rice & 159 & 303 & 324 & 326 & 332 & 323 & 374 \\
\hline 1)eviation ${ }^{2}$ & & 91 & 104 & 105 & 103 & 103 & 135 \\
\hline
\end{tabular}

\begin{tabular}{lcccccrr}
$\begin{array}{l}\text { Rainfall } \\
\text { Milletisorghum }\end{array}$ & 720 & 525 & 579 & 586 & 602 & 692 & 656 \\
$\begin{array}{l}\text { Deviation }^{2} \\
\text { Maize }\end{array}$ & -27 & -20 & -19 & -16 & -4 & -9 \\
Deviation $^{2}$ & 880 & 1,033 & 882 & 938 & 1,412 & 931 & 798 \\
Pacldy rice $_{\text {Deviation }^{2}}$ & & 17 & 0 & 7 & 60 & 6 & -9 \\
& 557 & 399 & 51.5 & 328 & 453 & 585 & 429 \\
& & -28 & -8 & -41 & -19 & 5 & -23 \\
\hline
\end{tabular}

Sources: Malian authorities: and Fund still estimates.

'The crop year is April-March; the marketing year is November/October.

${ }^{2}$ Deviation in percent from the :annusl average of the $1960-90$ period.

${ }^{3}$ Rainfall is measured for the specific area where cach cereal is grown. 
Table 5. Mali: Quarterly Retail Prices for Cereals, $1995200 \mathrm{i}$

(l) C:A francs per silogram!

Annal sverages

\begin{tabular}{|c|c|c|c|}
\hline 1995 & 109.6 & $\therefore 1<8$ & 2588 \\
\hline 1996 & 151.3 & $: 39.3$ & 266.5 \\
\hline 1997 & 121.3 & 121.5 & 244.8 \\
\hline 1998 & 149.0 & 144.8 & 259.0 \\
\hline 1999 & 132.7 & 124.7 & 255.9 \\
\hline 2000 & 97.8 & 98.8 & $2-6.0$ \\
\hline \multicolumn{4}{|l|}{1095} \\
\hline I & 88.0 & 98.11 & $22 \% 0$ \\
\hline II & 91.5 & 1120 & 2640 \\
\hline ili & 1320 & 127.0 & 274.10 \\
\hline IV & 127.0 & 122.0 & 270.0 \\
\hline \multicolumn{4}{|l|}{1996} \\
\hline 1 & 114.0 & 114.0 & 254.0 \\
\hline 11 & 151.0 & 144.0 & 277.0 \\
\hline Iil & $1 \times 4,0$ & 173.1 & 2850 \\
\hline IV & 150,0 & 127.0 & 250.0 \\
\hline \multicolumn{4}{|l|}{1997} \\
\hline I & 127.0 & 123,0 & 248.0 \\
\hline II & 1250 & 124.0 & 2410 \\
\hline ill & 1180 & 175,0 & $249 n$ \\
\hline JV & 1150 & 114.0 & $241.1)$ \\
\hline \multicolumn{4}{|l|}{$199 x^{1}$} \\
\hline I & 113.0 & 117,0 & 227.0 \\
\hline [] & 151.0 & 143.0 & 250.0 \\
\hline III & .177 .0 & 178.0 & 391,0 \\
\hline IV & 1550 & 141.0 & 2680 \\
\hline \multicolumn{4}{|l|}{1999} \\
\hline I & .30 .0 & 126.0 & 231.0 \\
\hline $1:$ & 141.0 & 129,0 & 262.0 \\
\hline III & 140.0 & 12600 & 274,0 \\
\hline IV & 119.8 & 117.7 & 256.7 \\
\hline \multicolumn{4}{|c|}{$2000^{\circ}$} \\
\hline 1 & 99.9 & 99.7 & 240.4 \\
\hline !! & 95.7 & 97.6 & 238.8 \\
\hline III & 96.3 & 98.4 & 255.1 \\
\hline FV & 99.1 & 99.3 & 249.5 \\
\hline \multicolumn{4}{|c|}{$200 !^{2}$} \\
\hline 1 & 108.8 & 108.5 & $24 \hat{3} .5$ \\
\hline II & 147.8 & 146.] & 244.9 \\
\hline
\end{tabular}

Sourec: Malian athoritis: and Fund staft estmates.

Tree ilarket prices represent the average of p ises provailing in 13 Banako markets.

2 Estimates. 
Table 6. Mali: Office du Niger - Indicalurs of Activity, 1994/95-2000/01 ${ }^{1}$

\begin{tabular}{lcc}
\hline $\begin{array}{c}\text { Area Cultivated } \\
\text { with Rice } \\
\text { (In hectares) }\end{array}$ & $\begin{array}{c}\text { Paddy Rice } \\
\text { Harvested } \\
\text { (in metric tons) }\end{array}$ \\
\hline $1994 / 95$ & 46,740 & 209,979 \\
$1995 / 96$ & 50,911 & 238,803 \\
$1996 / 97$ & 54,102 & 267.980 \\
$1997 / 98$ & 53,876 & 277,182 \\
$1998 / 99$ & 50,026 & 295,000 \\
$1999 / 00$ & 55,727 & 321,480 \\
$2000 / 01$ & 64,037 & 365,122 \\
\hline
\end{tabular}

Source: Malian authorities.

'The crop year is April-March. 
Table 7. Mali: Inplementation of the Public Investment Program, 1995-2000

(In billions of CFA franes)

\begin{tabular}{|c|c|c|c|c|c|c|}
\hline & 1995 & 1996 & 1997 & 1998 & 1999 & 2000 \\
\hline Rural development & 53.1 & 57.8 & 63.9 & 50.8 & 61.4 & 31.8 \\
\hline Agriculture & 43.0 & 45.8 & 53.8 & 39.5 & 53.8 & 28.6 \\
\hline Livestock & 4.3 & 5.0 & 5.3 & 5.1 & 4.7 & 1.2 \\
\hline Fisberies & 0.1 & 0.1 & 0.0 & 0.0 & 0.0 & 0.0 \\
\hline Furestry & 5.7 & 6.9 & 4.8 & 6.2 & 2.9 & 2 \\
\hline Sacondary sector & 20.9 & 26.0 & 39.2 & 62.3 & 45.4 & 45.2 \\
\hline Mines and geology & 0.5 & 1.2 & 1.2 & 0.8 & 1.4 & 0.8 \\
\hline Water & 13.4 & 16.9 & 18.2 & 20.2 & 16.8 & 9.2 \\
\hline Energy & 6.9 & 7.6 & 18.7 & 39.8 & 25.7 & 34.8 \\
\hline Industry and liandicrafts & 0.1 & 0.3 & 1.] & 1.5 & 1.5 & 0.4 \\
\hline Tourism & 0.0 & 0.0 & 0.0 & 0.0 & 0.0 & 0.0 \\
\hline Infiastructure & 24.2 & 32.2 & 39.9 & 41.1 & 62.5 & 63.4 \\
\hline Roads & 13.1 & 21.7 & 23.5 & 25.7 & 24.6 & 23.5 \\
\hline Railroads & 0.1 & 0.0 & 0.0 & 1.7 & 7.7 & 4.6 \\
\hline Air transport and nelereology & 0.6 & 0.2 & 0.6 & 1.0 & 4.2 & 4.7 \\
\hline Post and telecommunicalions & 3.8 & 3.4 & 4.4 & 2.4 & 3.7 & 6.2 \\
\hline Surveying und mapping & 0.1 & 0.2 & 0.2 & 0.1 & 0.3 & 0.3 \\
\hline Ruildings and equipment & 4.6 & 5.2 & 5.5 & 5.1 & 7.8 & 7.5 \\
\hline Urban development and housing & 1.7 & 1.2 & 5.3 & 4.2 & 13.6 & 15.6 \\
\hline Transport and storage & 0.2 & 0.3 & 0.4 & 0.6 & 0.6 & 1.0 \\
\hline Ifuman resources & 39.1 & 45.8 & 33.6 & 42.8 & 48.0 & 39.9 \\
\hline Employment & 6.7 & 7.1 & 2.4 & 1.0 & 1 & 1.2 \\
\hline Education & 9.9 & 9.4 & 10.4 & 15.8 & 16.1 & 8.7 \\
\hline Sports, arts, and culture & 0.4 & 0.4 & 0.5 & 3.9 & 5.8 & 10.9 \\
\hline Hoalh & 11.8 & 13.7 & 9.9 & 8.0 & 11.7 & 11.4 \\
\hline Information & 0.5 & 1.1 & 1.5 & 4.3 & 3.2 & 1.6 \\
\hline Adnuinistration & 9.8 & 14.1 & 8.9 & 9.8 & 10.2 & 6.1 \\
\hline Total & 137.3 & 161.8 & 176.6 & 197.0 & 217.3 & 180.3 \\
\hline
\end{tabular}

Source: Malian authorities. 
Table 8. Mali: The Investment Budgel for 1995-2000 and

Existing Connmitments livr Public Investment, 2001-2003 ${ }^{1}$

(Ji) billions of CFA frartes)

\begin{tabular}{|c|c|c|c|c|c|c|c|}
\hline & 1945 & 1946 & $: 407$ & 1598 & 1949 & 2000 & $\begin{array}{l}\text { 2001+0s } \\
\text { Existing } \\
\text { Commithents }\end{array}$ \\
\hline Itual deveioprent & 67.1 & 60.8 & 66.3 & 60.7 & 64.7 & 63.3 & 243.6 \\
\hline Agncultues & 53.5 & 46.2 & $5] .3$ & 49.4 & 55.1 & 55.2 & 229.4 \\
\hline Livestuck & 7.4 & 7.3 & 7.0 & 50 & 7.2 & 5.1 & 7.0 \\
\hline Fisherics & 0.1 & 0.11 & 0.0 & 0.0 & 0.0 & 0.0 & 2.2 \\
\hline Eorestry & 6,1 & 7.3 & 80 & 5.4 & 2.4 & 30 & 4.4 \\
\hline Sccondary sector & 27.4 & 36.6 & 42.1 & 55.0 & 51.8 & 41.2 & 63.6 \\
\hline Mir.es & 1.4 & 1.1 & 12 & 13.7 & $3 \%$ & 1.9 & 6.2 \\
\hline Wuter & 12.1 & 18.3 & 17.5 & 21.9 & 194 & 10.2 & 23.1 \\
\hline Energy & 13.6 & 17.0 & 25.1 & 31.9 & 26.7 & 26.7 & 29.0 \\
\hline Hatustry & 0.1 & 0.1 & 0.3 & $1: 5$ & 1.9 & 2.3 & 5.2 \\
\hline Tuaris:is & 0.1 & 0.1 & (1) 1$]$ & 0.0 & 0.0 & 0.0 & 0.0 \\
\hline Infrestructure & 30.1 & 33.0 & 39.8 & 63.5 & 74.5 & 90.6 & 237.7 \\
\hline Roarls & 20.5 & 2.5 & 286 & $2 \times .1$ & 31.9 & 397 & 3.36 .2 \\
\hline Rairroacs & 2.6 & 3.3 & 2.1 & 0.4 & 6.3 & 7.4 & 21.2 \\
\hline Air trarspost & 0.8 & 0.4 & 1.0 & 1.9 & $4 .:$ & $5 . A$ & 4.2 \\
\hline Post ane telocomminicatous & 2.8 & 0.6 & 0.6 & 56 & 6.4 & 8.5 & 8.7 \\
\hline Surveying & 0.1 & 0.1 & 0.2 & 0.2 & 0.2 & 0.4 & 0.5 \\
\hline Juildings & 2.7 & 5.1 & 5.2 & 5.4 & 7.8 & 7.5 & 43.1 \\
\hline 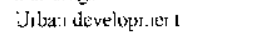 & 1).3 & 1.4 & 1.4 & 14.5 & 160 & 14.2 & 23.1 \\
\hline T:anspot and storags & 0.2 & 0. 6 & 0.7 & 1.2 & 1.6 & 2.3 & 0.5 \\
\hline Hume,11 resulatchis & 42.8 & 50.6 & 50.3 & $4 u ̈ . l$ & 43.9 & 56.5 & 160.6 \\
\hline Employment & 3.6 & 6.2 & 3.8 & 1.1 & 0.9 & 1,5 & 0.3 \\
\hline Fichotion & 9.8 & 8.6 & $12 . R$ & 125 & 17.6 & 13.9 & 45.5 \\
\hline Sports, alts and suldiare & 0.3 & 0.2 & 0.4 & 1.? & 1.6 & 110 & 32.1 \\
\hline Health & 16.6 & 21.6 & 18.1 & 3.9 & 10.7 & 21.1 & 35.5 \\
\hline Ir tomation & 1.0 & 1.5 & 2.2 & 3.7 & 3.5 & 1.1 & 1.3 \\
\hline Adrni:uistrutior: & 11.5 & 11.9 & 13.0 & 8.5 & 9.4 & 8.7 & 4.5 .7 \\
\hline Total & 167.4 & 180.4 & 198.5 & $2: 9.4$ & 234.9 & 251.6 & 704.9 \\
\hline Firancing & 167.4 & $180 .:$ & 198.5 & $2: 9.3$ & 234.9 & 251.6 & 704.9 \\
\hline Exterski financitig & 140.9 & 147.3 & 155,6 & $17: 3$ & 181.1 & 198.3 & $56 \% .8$ \\
\hline Loans & 74.3 & 70.1 & 792 & 92.7 & 98.3 & 113.6 & 3.33 .5 \\
\hline Gralls & 66.6 & 77.2 & 76,4 & 84.6 & 831 & 79.7 & .953 \\
\hline Jornsstic financing & 26.5 & 33,1 & .12 .9 & 42.0 & 53.5 & 53.3 & 136.1 \\
\hline Bucinet & $\sin$ & 24.2 & 23.6 & 25.8 & 35.1 & 46.2 & 126.6 \\
\hline Self-1:narcing & $\leq 2$ & 7.7 & 12.8 & 12.6 & 51 & 6.2 & 4.2 \\
\hline Other & 1.3 & 1,2 & 1.5 & 3.3 & 3.3 & 0.9 & 5.3 \\
\hline
\end{tabular}

Sousce: Matian autjoritics.

' Jata differ from those included in tubles un governuent indatlial operations. as an implementation rate of less than lio percent is ass.uned in the projectinus. 
Table 9. Mali: Livestock Exports, Slaughtering, and Herd Size, 1995-2000

(In thousands of head, unless otherwise indicated)

1.995
Cattle Sheep
and
goals

$\frac{1996}{\text { Cattle } \quad \begin{array}{r}\text { Sheep } \\ \text { and } \\ \text { goats }\end{array}}$

$\frac{1997}{\text { Cattle } \begin{array}{r}\text { Sheep } \\ \text { and } \\ \text { goats }\end{array}}$

$\frac{1998}{\text { Cattle } \quad \begin{array}{r}\text { Sheep } \\ \text { and } \\ \text { goats }\end{array}}$

$\begin{array}{rrrr}\text { Calle } & \begin{array}{c}\text { Sheep } \\ \text { and }\end{array} & & \text { Catlle } \\ \text { goats } & & \begin{array}{r}\text { Sheep } \\ \text { and } \\ \text { goats }\end{array}\end{array}$

\begin{tabular}{|c|c|c|c|c|c|c|c|c|c|c|c|c|}
\hline Exports & 418 & 925 & 216 & 537 & 396 & 925 & 308 & 758 & 293 & 654 & 398 & 990 \\
\hline Controlled & 107 & 426 & 65 & 215 & 119 & .349 & 108 & 259 & 129 & 324 & 279 & 440 \\
\hline Uncontrolled & 311 & 499 & 151 & 322 & 277 & 576 & 200 & 499 & 164 & 330 & 119 & 550 \\
\hline Slaughtering & 547 & 2.007 & 425 & 2,137 & 450 & 2,025 & 347 & 2,212 & 382 & 2.433 & 423 & 3,626 \\
\hline Comrralled & 192 & 321 & 149 & 321 & 158 & 319 & 172 & 395 & 191 & 432 & 279 & 419 \\
\hline Uncontrolled & 355 & 1,686 & 276 & 1,816 & 292 & 1,706 & 175 & 1,817 & 191 & 2,001 & 144 & 3,207 \\
\hline $\begin{array}{l}\text { Estimated herd size } \\
\text { (end of period) }\end{array}$ & 5.708 & 13.179 & 5,882 & 13,809 & 6,058 & 14,500 & 6,240 & 15,225 & 6,427 & 15,986 & 6,692 & 16,785 \\
\hline \multicolumn{13}{|l|}{ Mennorandum items: } \\
\hline Net birth rate (in percent) & 1.1 & 3,6 & $\ldots$ & $\ldots$ & $\ldots$ & $\ldots$ & $\ldots$ & $\ldots$ & $\ldots$ & $\ldots$ & $\ldots$ & .. \\
\hline Offtake ratc (in percent) & 16.9 & 22.2 & 10.9 & 19.4 & 14.0 & 20.0 & 10.5 & 19.5 & 10.5 & 19.3 & 12.3 & 30.0 \\
\hline
\end{tabular}

Source: Malian authorities.

'Provisional data. 
Table 10. Mali: Index of Industrial Production, 1995-2000

$\begin{array}{llllll}1995 & 1996 & 1997 & 1998 & 1999 & 2000\end{array}$

(Index, 1983=100)

Chemicals and construction materials $\begin{array}{llllll}127.5 & 143.6 & 135.8 & 129.0 & 114.4 & 108.3\end{array}$

Energy and machinery $\begin{array}{llllll}211.8 & 224.9 & 257.4 & 296.8 & 282.6 & 308.3\end{array}$

Food processing

$\begin{array}{llllll}133.7 & 139.6 & 147.2 & 135.4 & 129.9 & 209.2\end{array}$

'J'extiles

$\begin{array}{llllll}173.2 & 199.5 & 255.6 & 255.1 & 222.2 & 193.5\end{array}$

Overall index

$\begin{array}{llllll}158.2 & 173.1 & 199.8 & 201.5 & 182.6 & 208.7\end{array}$

(Annual percentage change)

Chemicals and construction materials

9.2

12.6

$-5.4$

$$
-5.0
$$

$-11.3$

Encrgy and machinery

21.2

6.2

14.5

15.3

$-4.8$

9.1

Food processing

$-0.4$

4.4

5.4

$-8.0$

$-4.1$

61.0

Textiles

16.2

15.2

28.1

$-0.2$

$-12.9$

$-12.9$

Overall index

10.2

9.4

15.4

0.9

$-9.4$

14.3

Source: Malian authorities. 
Table 11. Mali: Gold Production, by Company, 1995-2000

(Ur.less otherwise indicated, values in billinns of CFA frunes, volumes in metric tons, and unit values in ('l'A francs per kilogram)

\begin{tabular}{|c|c|c|c|c|c|c|}
\hline & 1995 & 1996 & 1997 & 1998 & 1999 & 2000 \\
\hline \multicolumn{7}{|l|}{ Toral gold exports } \\
\hline Value & 35.6 & 39.8 & 117.2 & 133.1 & 142.4 & 189.4 \\
\hline Volume & 6.2 & 6.6 & 18.5 & 22.8 & 25.3 & 28.3 \\
\hline Urit valie & $11,285.1$ & $11,759.3$ & 18.054 .7 & $16,718.7$ & 15.218 .0 & $25,683.2$ \\
\hline \multicolumn{7}{|c|}{ Morila (Ar:glo-Gold; also uperating Semos) } \\
\hline Value & 0.0 & 0.0 & 0.0 & 0.0 & 0.0 & 24. 1 \\
\hline Vohme & 0.0 & 0.0 & 0.0 & 0.0 & 0.0 & 3.5 \\
\hline Unit value & 0.0 & 0.0 & 0.0 & 0.0 & 0.0 & $6,929.0$ \\
\hline \multicolumn{7}{|c|}{ Syama (Som:sy - Randgold) } \\
\hline Valuc & 24.3 & 27.9 & 25.1 & 28.2 & 30.3 & 36.2 \\
\hline Yolume & 4.0 & 4.4 & 4.1 & 4.8 & 6.1 & 5.7 \\
\hline Unif value & $6,102.4$ & $6,356.4$ & $6,173.4$ & $5,813.0$ & $4,957.3$ & $6,392.0$ \\
\hline \multicolumn{7}{|c|}{ Sadiola (Ser:os - Anglo-Ameri:an) } \\
\hline Value & 0.0 & 0.0 & 80.4 & 93.8 & 102.6 & 116.4 \\
\hline Vo:ume & 0.0 & 0.0 & 12.2 & 15.7 & 17.0 & 16.8 \\
\hline Unit value & 0.0 & 0.0 & $6,583.7$ & $5,964.6$ & $6,047.0$ & $6,929.0$ \\
\hline \multicolumn{7}{|l|}{ Orpaillage } \\
\hline Value & 11.3 & 11.9 & 11.7 & 11,1 & 9.6 & 12.6 \\
\hline Volume & 2.2 & 2.2 & 2.2 & 2.3 & 2.3 & 2.3 \\
\hline Init valuc & $5,182.7$ & $5,402.9$ & $5,297.6$ & $4,941.1$ & $4,21.3 .7$ & $5,433.2$ \\
\hline \multicolumn{7}{|l|}{ Memorarthum itcm: } \\
\hline $\begin{array}{c}\text { Wo:le price in t } \\
\text { per kilugrarn }\end{array}$ & 6.164 .9 & 6.243 .9 & $7,085,5$ & 5.580 .1 & $5,519.3$ & $6,372.8$ \\
\hline
\end{tabular}

Source: Malins sathorities. 


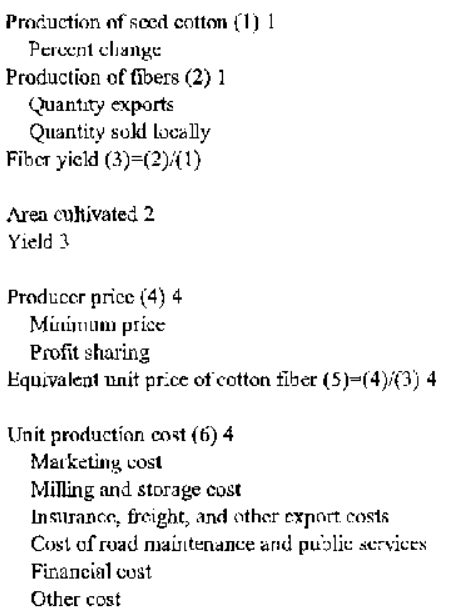

Total unil cost of caton fiher $(7)=(9) \mid\{6\} 4$

Average sale price of cotton fiber (9) 4

Total rerenue from cotton tiber (in billions of CF $A$ francs)

Froms exports

From local sales

Sale of cotton secd

Total cost on cottum fiber (iu billiuss of CFA fiancs)

Gross CMU'T protit (in billians of CFA francs)

Taxes and other government revenue (in billions of CFA franc3)

Avrage tax per k:iogram of cotton fiber

CMDT net profit before sod entton

Total (in billions of CFA francs)

Per kilogram of cotton fiber

Memurandums item:

Contribution to stabilization mechanism 4 !

Tclal unit cost, including stabijization ineclannsin 4 World cotton price (WEO) (10) $4 i$

$$
\text { Percent charge }
$$

Discount for Malian cotton (9)d(10) 5/

THiscur.tnt for Malian cotton (bil CFAF)

\begin{tabular}{|c|c|c|c|c|c|c|}
\hline 293.0 & 405.9 & 452.1 & 522.9 & 518.1 & 459.5 & 242.7 \\
\hline 21.8 & 38.5 & 11.4 & 15.7 & -0.9 & -11.3 & -47.2 \\
\hline 128.1 & 169.3 & 189.6 & 217.7 & 217.1 & 197.3 & 101.9 \\
\hline$\cdots$ & $\cdots$ & $\cdots$ & 2160 & 215.5 & 195.7 & 100.3 \\
\hline$\ldots$ & $\ldots$ & $\ldots$ & 1.7 & 1.6 & 1.6 & 1.6 \\
\hline 0.44 & 0.42 & 0.42 & 0.42 & 0.42 & 0.43 & 0.42 \\
\hline 269.8 & 336.3 & 418.6 & 494.2 & $502 .:$ & 472.8 & 228.4 \\
\hline 1.09 & $\therefore 21$ & 1.08 & 1.06 & 1.03 & 0.97 & 1.06 \\
\hline 130.0 & 155,0 & 155.0 & 170.0 & 185.0 & 150.0 & 170.0 \\
\hline 130.0 & 155.0 & $: 55.0$ & 140.0 & 145.0 & 15000 & 170.0 \\
\hline 0.0 & 0.0 & 0.0 & 30.0 & 40.0 & 0.0 & 0.0 \\
\hline 297.4 & 371.6 & .369 .6 & $40 \pi \cdot 4$ & 441.5 & 349.4 & 40.50 \\
\hline 356.4 & 340.2 & 371.6 & 405.3 & 410.9 & 419.6 & 466.9 \\
\hline 24.9 & 32.1 & 41.5 & 46.8 & 54.4 & 58.7 & 36.0 \\
\hline 103.3 & 103.1 & $1: 5.5$ & 225.0 & 126.6 & 129.0 & 122.2 \\
\hline 176.5 & 118.7 & $13 . \hat{x}$ & $: 35.6$ & 140.3 & 1.38 .3 & 123.4 \\
\hline 35.8 & 42.2 & 42.3 & 29.8 & 7.0 & 3.8 & 2.6 \\
\hline 2.7 & 6.3 & 6.9 & 27.9 & 37.6 & 46.5 & 63.8 \\
\hline 53.2 & 37.8 & 31.5 & 40.1 & 45.1 & 43.2 & 78.8 \\
\hline 653.8 & 711.8 & 741.2 & 817.6 & 8.52 .3 & 769.0 & 871.8 \\
\hline 928.9 & 231.1 & 879.8 & 9250 & $80 \% .5$ & 692.4 & 682.5 \\
\hline 119.0 & 157.6 & 166.8 & 203.2 & 177.5 & 140.4 & 71.5 \\
\hline$\cdots$ & $\ldots$ & $\ldots$ & 199.8 & 174.2 & 135.5 & 68.4 \\
\hline$\ldots$ & $\ldots$ & $\ldots$ & 0.9 & 0.9 & 0.8 & 1.1 \\
\hline (1). 9 & 1.3 & 29 & 2.5 & 2.4 & 4.1 & 2.0 \\
\hline 83.7 & 120.5 & 140.5 & 177.1 & 185.1 & 151.7 & 88.8 \\
\hline 35.2 & 37.1 & 26.5 & 26.1 & -7.5 & -11.3 & -17.3 \\
\hline 14.8 & 11.3 & 9.5 & 13.2 & 1.3 & 0.1 & 0.0 \\
\hline 115.9 & 66.6 & 50.3 & 60.5 & $0 . \overline{0}$ & 0.3 & 0.0 \\
\hline 20.4 & 25.8 & 16.7 & 12.9 & -8.8 & -11.3 & -17.3 \\
\hline 159.2 & 152.6 & $88 . \hat{j}$ & 59.7 & -40.7 & -57.4 & .169 .7 \\
\hline 22.5 & 36.9 & 15.1 & 17.2 & -3.5 & -38.3 & 0.0 \\
\hline 676.3 & 748.7 & 756.3 & 830.8 & 848.8 & 730.7 & 871.8 \\
\hline 1069.0 & 963.5 & 990.0 & 924.3 & 737.8 & 82.5 .1 & 879.9 \\
\hline 16.0 & -9.9 & 2.7 & -6.6 & -20.2 & 11.8 & 6.6 \\
\hline 13.1 & .3 .4 & -11.1 & 0.1 & 9.6 & -16.1 & -22.4 \\
\hline 179 & 5.5 & 20.9 & -0.2 & -15.3 & 26.2 & 20.1 \\
\hline
\end{tabular}

Somrocs: Malian authorities; and lund staffe estimates. Data are reported on CMUl's tinancial year, Octoler to Septeniber

1/Thousands of metric tons.

2/ 'Thousands of hectares.

3/ Tons per hectare.

4/ C.A francs per kilogram.

5i lu pexcent.

\section{CInternational Monetary Fund. Not for Redistribution}


Table 13. Mali: Quarterly Index of Consumer Prices in Bamakn, 1998:Q1-:200103

(Index, 1990-1009)

\begin{tabular}{|c|c|c|c|c|c|c|c|c|c|c|c|c|c|c|c|c|c|c|}
\hline & \multirow[b]{2}{*}{ I } & \multirow[b]{2}{*}{ !1 } & \multicolumn{2}{|l|}{1998} & \multirow[b]{2}{*}{ (Annual) } & \multicolumn{4}{|c|}{1999} & \multirow[b]{2}{*}{ Annusal) } & \multicolumn{3}{|r|}{2000} & \multirow[b]{2}{*}{$\mathrm{rr}$} & \multirow{2}{*}{ Annualy } & \multicolumn{2}{|r|}{2001} & \multirow[b]{2}{*}{ IIT } \\
\hline & & & III & IV & & I & II & III & IV & & $\mathrm{T}$ & [] & III & & & I & [1] & \\
\hline Food & 95.2 & 103.5 & 111.9 & 103.5 & 1013.5 & 96.5 & 100.6 & 104.9 & 98.9 & 100.2 & 92.7 & 94,0 & 97.9 & 98.6 & 95.6 & 957 & 102.1 & 108.0 \\
\hline Cholhing & 104.1 & 105.0 & $: 05.1$ & 104.7 & 104.7 & 108.9 & 108.1 & 108.1 & 109.1 & 108.6 & 103.3 & 10.9 & 104.9 & 105.3 & 104.3 & 106.5 & 109.7 & 10.6 \\
\hline Housing, water, and encrgy & 97.7 & 99.4 & 98.3 & 98.5 & 98.5 & 98.0 & 988 & 106.3 & 107.3 & 102.6 & 103.7 & 102.5 & $: 05.9$ & 107.2 & 104.8 & 100.9 & 108.1 & 111.4 \\
\hline Funviture antd household article & 101.7 & $|\cap| 1.7$ & 103.0 & $j 02,1$ & 002.1 & 104.9 & 105.0 & 105.1 & 1051 & 1050 & 108.0 & $: 08.7$ & 1096 & 1.10 .0 & 109.1 & $\ln 6.3$ & 106.5 & 106.5 \\
\hline Health: & 101.9 & 1028 & 102.6 & 102.4 & 102.4 & 109.6 & 1098 & 109.5 & 110.0 & 109.1 & 102.8 & 101.8 & 101.8 & 102.8 & 102.3 & 102.5 & 103.5 & 104.0 \\
\hline Transport and communicetious & 99.9 & 100.0 & 100.0 & 100.0 & 100.0 & 99.9 & 100.0 & 100.4 & 99.9 & 100.1 & 100.8 & 114.1 & 113.8 & 113.9 & 1105 & 114.7 & 114.8 & 1140 \\
\hline Leisure and entcrtainmeut & 102.6 & 102.8 & 102.8 & 102.7 & 102.7 & 100.7 & 100.3 & 100.4 & 100.8 & 100.6 & y. & 99.1 & 99.0 & 99.0 & 99.0 & 00.8 & 99.5 & 99.7 \\
\hline Chicr gnods athd services & 114.3 & 113.8 & 114.3 & 114.1 & 114.1 & 110.8 & 110.9 & 111.6 & 112.4 & 111.4 & 114.0 & 113.3 & 113.5 & 113.3 & 113.5 & 114.6 & 114.5 & 114.6 \\
\hline Totais $^{2}$ & $9 \times .6$ & 163.0 & 107.2 & 104.4 & 103.3 & 99.7 & 101.9 & 1050 & 102,0 & 202.1 & os.t. & 100.5 & 103.0 & 103.4 & 101.4 & 102.3 & 105.9 & 109.2 \\
\hline
\end{tabular}

Sulrec: Maitan atthotilies.

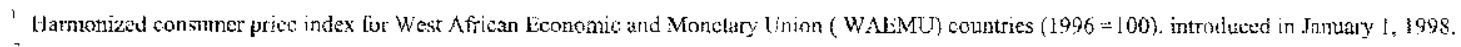

${ }^{2}$ Weighted total.

CInternational Monetary Fund. Not for Redistribution 
Table 14. Mali: Minimum Wages and Sularies in the Publiz Sector, 1995-2000

(In CF $A$ francs por month)

$\begin{array}{llllll}1995 & 1996 & 1997 & 1998 & 1999 & 2000\end{array}$

Est.

\section{Contractual workers}

Mininum wage for unskilled agricultural workers ( $\mathrm{MAG}$ )

Basic wage

Special allowarce

Cost of living allowance

Solidarity allowance

Mininum wage for unskilled workers outside agriculture (SVIG)

Basic wage

Special allowance

Cost of living aljowanes

Ad justment of March 1980)

Solidarity allowance

Government employces

Grade 100

Base salary

Housing kilownec

Special aliowance

Solidarityallowance

Gade 316

Base salary

Housing allowance

Solidarity allowance

Grade 650

Base sa.ary

Housing allowance

Solidarity allowance

$\begin{array}{rrrrrr}33,800 & 34,040 & 34,040 & 35,340 & 37,254 & 41.637 \\ 24,800 & 26,040 & 26,040 & 27,340 & 29,254 & 33,637 \\ 1,500 & 1,500 & 1,500 & 1,500 & 1,500 & 1,500 \\ 1.000 & 0 & 0 & 0 & 0 & 0 \\ 6,500 & 6,500 & 0,500 & 6,500 & 6,500 & 6,500\end{array}$

$\begin{array}{rrrrrr}81,868 & 85,786 & 85,780 & 89,894 & 95,942 & 109,677 \\ 78,368 & 82,286 & 82,286 & 86,394 & 92,442 & 106,177 \\ 1.500 & 1,500 & 1,500 & 1,500 & 1,500 & 1,500 \\ 2,000 & 2,000 & 2,000 & 2,000 & 2,000 & 2,000\end{array}$

$\begin{array}{rr}164,700 & 172,760 \\ 161,200 & 169,260 \\ 1,500 & 1,500 \\ 2,000 & 2,000\end{array}$

172.760

181.210

193,650

221,998

169.260

177,710

$194,150 \quad 218,498$

1.500

1.500

1,500

1,500

2000

2,000

2,000

Source: Malian authoritics. 
Table 15. Maib: Employment i: the Central a:d

Regional Governments and the Public Enterprise Secter, 1995-2000

(Vumbers of empioyecs)

\begin{tabular}{|c|c|c|c|c|c|c|}
\hline & 1995 & 1946 & 1.997 & 1998 & 1799 & $\begin{array}{r}2000 \mathrm{j} \\
\text { Est. }\end{array}$ \\
\hline tontral and regional governments & 32,527 & $36,1,38$ & 37,340 & 37,661 & 40,457 & 43,980 \\
\hline Civil servants & 29.067 & 31,961 & 33,235 & 33,534 & 34,226 & 35,458 \\
\hline Comeractual employees and other & 3,460 & 4,177 & 4,105 & $4,2: 27$ & 6,231 & 8,521 \\
\hline Prblic enterprisess ${ }^{1}$ & 8,531 & 8,230 & 7,801 & 7,858 & $7,3.59$ & 4,883 \\
\hline
\end{tabular}

Source: Malian authorities.

I The publie entemprises included here are as follows: Compagnie Malienne de Vavigatimn (COMANAV), Fnetgie du Mali (EDM), Entreprise Malicne de Mainzonan ze (EMAMA).

Office d'Expoitation des Ressoures Hydrauliques du Hau Niger (OERHR), OlFic National des Postes (ONP), Oflice de Rilio et Télevisiur (ORT), Socièté c'Equipement du Mali (SEMA), Soctété Nationale des Tatats et Allumettes du Mali (SONATAM), and Line Malionne de Produits Phannacuitures (IMPP). 
Table :6. Mali: Consolidated Government Operations, 1995-2050 (conctuded)

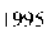

1996

1997

1998

1999

(In percent of GDP, unless otherwise indicated)

Defic:t (commitment hasis)

Excluding Rrants

Ircluding grants

Deficit (caslt basis)

Excluding gran:s

Including grants

Nemorandum item:

Mili:ary spendits (billons of CFA frencs $s^{5}$
$-3.2$

$-11.1$

$-3.4$

$-0.9$

$-12.3$

$-4.5$

$-9.6$

$-2.3$

$-8.7$

$-2.8$

$-8.1$

$-2.2$

$-8.1$

$-2.4$

$-8.7$

$-3.1$

8.5

$-3.5$

$-9.3$

$-3.7$

Sources: Malian allhorities; and Fusd slaî estimates.

'Schcduled; $\varepsilon$ ter debt canceliation obtained thro lgh 1993.

'PLSAP, Public Lintecprise Sector Adjustment I'rogram, -inanced hy the World Raris and cofinancicrs.

${ }^{3}$ Based on the carcellatiun of ufficial develspment assistance (ODA) dabt obtaiced in 1994.

${ }^{4}$ Expenditure by the Ministry of National Defense. 
Table 17. Mali: Government Revenue, 1995-2000

(In billions of CFA francs)

\begin{tabular}{|c|c|c|c|c|c|c|}
\hline & 1995 & 1996 & 1997 & 1998 & 1999 & 2000 \\
\hline Taxes on net income and profits & 26.6 & 34.5 & 37.8 & 42.8 & 34.7 & 45.4 \\
\hline Enterprises & 10.8 & 19.7 & 20.9 & 25.0 & 17.4 & 23.7 \\
\hline Public & 0.8 & 0.1 & 2.9 & 0.6 & 0.4 & 0.0 \\
\hline Private & 10.0 & 19.6 & 18.0 & 24.4 & 17.0 & 23.7 \\
\hline Ind:viduals & 14.2 & 12.6 & 14.5 & 16.6 & 15.6 & 20.2 \\
\hline Tax on transporters & 0.6 & 1.0 & 1.1 & 1.2 & 1.6 & 1.5 \\
\hline Rental income tax & 1.0 & 1.2 & 1.3 & 0.0 & 0.0 & 0.0 \\
\hline Payroll tax & 2.5 & 3.7 & 3.9 & 4.6 & 4.7 & 1.8 \\
\hline Property taxes & 3.4 & 6.4 & 4.9 & 3.2 & 4.8 & 6.9 \\
\hline Taxes on gonds and services & 17.0 & 25.4 & 26.5 & 30.9 & 39.7 & 42.1 \\
\hline Value-added lax & 13.8 & 22.8 & 23.0 & 24,3 & 30.3 & 35.1 \\
\hline Public enterprises & 9.3 & 19.8 & 20.4 & 20.0 & 27.9 & $3 \mathrm{i} .5$ \\
\hline Private enterprises & 4.5 & 3.0 & 2.6 & 4.4 & 2.5 & 3.6 \\
\hline Exc:sc duties ${ }^{2}$ & 1.4 & 0.7 & 1.8 & 1.6 & 1.4 & 1.9 \\
\hline Other & 1.8 & 1.9 & 1.8 & 4.9 & 8.0 & 5.1 \\
\hline Taxes on international trade & 73.0 & 94.5 & 112.6 & 127.8 & 135.4 & 123.1 \\
\hline Customs duties $^{2}$ & 5.4 & 6.6 & 7.8 & 10.7 & 23.8 & 29.2 \\
\hline Other import charges ${ }^{2}$ & 22.9 & 29.0 & 35.4 & 37.3 & 7.2 & 0.0 \\
\hline Value-added tax on imports ${ }^{\prime}$ & 20.8 & 31.6 & 34.2 & 35.3 & 45.1 & 46.5 \\
\hline Petrolcum import dutics ${ }^{2}$ & 21.2 & 24.6 & 29.2 & 33.4 & 48.3 & 37.0 \\
\hline Payment of deferred taxes & 0.7 & 1.2 & 1.7 & 0.8 & 1.1 & 0.0 \\
\hline Lixport duty ${ }^{3}$ & 0.1 & 0.1 & 2.1 & 3.4 & 3.0 & 4.0 \\
\hline Other & 1.9 & 1.5 & 2.0 & 7.0 & 7.0 & 6.3 \\
\hline Other tax revenue & 9.0 & 8.4 & 10.6 & 12.0 & 16.0 & $1: .1$ \\
\hline Stamp duties & 4.8 & 5.3 & 5.3 & 5.8 & 6.8 & 4.6 \\
\hline Payment of tax artears & 28 & 2.0 & 2.0 & 2.3 & 5.0 & 9.4 \\
\hline Other taxes & 1.4 & 1.0 & 3.4 & 4.0 & 4.3 & 3.1 \\
\hline Iax revenue & 131.5 & 172.8 & 196.3 & 721.3 & 2.35 .3 & 233.3 \\
\hline Nontax revenue & 9.0 & 12.2 & 11.6 & 10.4 & 12.6 & 12.2 \\
\hline Budgetary revenue & 140.5 & $\mathbf{1 5 5 . 0}$ & 207.9 & 231.7 & 247.8 & 245.5 \\
\hline Special funds and annoxed budgets & 16.6 & 20.9 & 21.8 & 23.2 & 24.8 & 24.4 \\
\hline Total revenur & 157.1 & 205.9 & 222.7 & 254.9 & 272.6 & 269.9 \\
\hline
\end{tabular}

Source: Nialian authontites.

I Entrodileed in :99? and replated thenewer tax.

${ }^{2}$ Beginning in 1901 , tax revenues ir cluded in this category, which were previously earmarked for specjal funds, have been consulidated in the budget.

${ }^{t}$ Clistonis service foc on gold cxports. 


\begin{tabular}{|c|c|c|c|c|c|c|}
\hline & 1995 & 15246 & 14967 & $144 \mathrm{p}$ & 1944 & $2: 04$ \\
\hline & \multicolumn{5}{|c|}{ (In billions of $C A$ fretnes) } & \\
\hline Taxes or net ire ane and profits & $2 n, 6$ & 34.5 & .7 .8 & 42.5 & 34.7 & 45.4 \\
\hline Taxes of: goods and services & 17.11 & 2.5 .4 & 265 & $3 \% .4$ & 39.7 & $\angle 2.1$ \\
\hline Payoll tas & 25 & 3.7 & 3,5 & 1,6 & 4.7 & 4.8 \\
\hline Priperiy taxes & 3.4 & 64 & 49 & 3.2 & $4 . x$ & 69 \\
\hline Tuxes on international trads: & 73.0 & 94.5 & 112.6 & $\mathrm{i} 278$ & 1.35 .4 & 123.1 \\
\hline Othrer tax listalde & 4.0 & $\$ 4$ & I1]... & 12.6 & Itith & 11.1 \\
\hline Tax revenue & 171.5 & $1: 2 . x$ & lyan & 221.3 & 235.3 & 233.3 \\
\hline Nmitax revente & 2.0 & .2 .2 & 116 & 10.4 & 13.6 & 2.2 \\
\hline [3udute :ary revciat: & $14: 5$ & 185.0 & 207.9 & 231.7 & 217.8 & $2 \cdot 15.5$ \\
\hline Special lintds and anxexed budgers & $: 6.6$ & 20.9 & 21.8 & 23.2 & 24.8 & $2-1.4$ \\
\hline \multirow[t]{2}{*}{ Total reyenuce } & $157:$ & 205.9 & 229.7 & $25+9$ & 272.6 & 269.9 \\
\hline & \multicolumn{5}{|c|}{ !Anual perentrge clzangel } & \\
\hline Taxes cin net incone and profits & 6.4 .5 & 29.3 & 以: & 13.3 & -10.0 & 30.8 \\
\hline Taxes on goods and servicas & 1.3 .4 & 49.2 & 4.6 & $: 6.4$ & 28.4 & 6.2 \\
\hline T'axcs rin inct:ax'mal "racic & 32.5 & 29.5 & 19.1 & $: 3.5$ & 5.9 & -9.1 \\
\hline therer tax revenu: & .25 .7 & $\cdot 6.5$ & 20.7 & $: 3.3$ & 33.0 & 30.8 \\
\hline Tax rescric & 274 & 31.1 & 13.6 & $: 2, ?$ & 6.3 & -0.8 \\
\hline Nontex iveriue & 48.8 & 35.6 & -4.9 & -10.6 & 21.1 & -2.8 \\
\hline Budg:tary rovelue & 28.5 & $3: 7$ & $i 2.4$ & 11.5 & 69 & -0.9 \\
\hline Spcuial finds and annexud budges & 28.3 & 20.0 & 4.4 & 6.1 & 6.8 & -16 \\
\hline \multirow[t]{2}{*}{-out reverue } & 28.5 & 31.1 & 11.6 & 11.0 & 6.9 & -1.0 \\
\hline & \multicolumn{5}{|c|}{ (II pecer ol budg:lary revanues } & \\
\hline 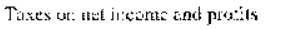 & 19.j & 18.6 & $1 \times .2$ & 18.2 & 14.0 & $18 . \overline{3}$ \\
\hline Taxes ob goods and servicas & 12.1 & $1.3 . i$ & 12.8 & 13.3 & 160 & 17.1 \\
\hline Taxes on intenational tradt: & $\leq 2 .:$ & sı.1 & 5.4 .1 & 55.2 & 54.6 & 50.1 \\
\hline 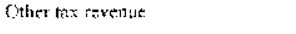 & 6. 4 & 4.5 & 5.1 & 5.2 & 6.5 & 1.5 \\
\hline Tax revenue: & 93.0 & 93.4 & 94.4 & 25.5 & 91.9 & 95.10 \\
\hline \multirow[t]{2}{*}{ Nanax ievemes: } & 3.4 & 0.6 & st & 4.5 & 5.1 & $5.1]$ \\
\hline & \multicolumn{5}{|c|}{ 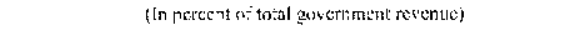 } & \\
\hline Budperacy rewente & $81), 4$ & 89.8 & th.5 & $90, y$ & 40). 4 & $\because 1 .:$ \\
\hline \multirow[t]{2}{*}{ Spcoial livends and annexed budgers } & 30.6 & $\ln 2$ & 9.5 & 4.1 & ) 1 & 9.6 \\
\hline & \multicolumn{5}{|c|}{ 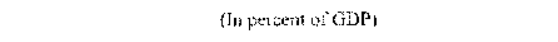 } & \\
\hline Tit kes en ac: necme and protits & 2.2 & 2.6 & 2.7 & 2.7 & 2.1 & 2.5 \\
\hline Tuses on goods and tervices & 1.4 & 1.9 & 1.9 & 1.5 & 2.4 & 2.3 \\
\hline Тахеs on isternationial traric & 6.2 & 7.2 & 7.9 & 8.0 & 8.1 & 6.8 \\
\hline Otno: tox revenue & $c . S$ & 1.6 & 0.7 & 0.8 & $1.0 \mathrm{i}$ & the \\
\hline Tax ieverus & $\therefore 1 .:$ & $: 3 .:$ & 13.8 & 13.5 & 14.1 & 12.4 \\
\hline Vontex revadude & t), 8 & 0.9 & 0.8 & 0.7 & $0 . x$ & 0.7 \\
\hline Mudg:tary revinuc & 11.5 & $1 \therefore 0$ & 146 & 14.6 & 14.8 & 13.6 \\
\hline Special tinds and amexed bujestor & 1.4 & $i .6$ & 1.5 & 1.5 & 1.5 & 1.3 \\
\hline Toual ieverue & 13.2 & 15.0 & $: 6 .:$ & 16.0 & 16.3 & 14.9 \\
\hline
\end{tabular}

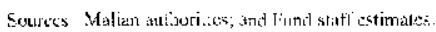


Table 19. Mali: Government Expenditurc. 1995-2000

\begin{tabular}{|c|c|c|c|c|c|c|}
\hline & $: 995$ & 1996 & 1997 & 1998 & 1999 & 2000 \\
\hline & \multicolumn{6}{|c|}{ (In billiors of (CFA francs) } \\
\hline Expendizure and net lcnding & 289.4 & 314.2 & 345.2 & 383.5 & $4: 7.6$ & 439.2 \\
\hline Budgetasy expendit „re & 291.8 & 303.9 & 328.6 & 363.9 & 3950 & $4 \mid 7.3$ \\
\hline Current expendi:ure & 134.7 & $\mathrm{i} 37.1$ & 167.7 & 167.8 & 193.2 & 199.3 \\
\hline l'ersonnel & 48.0 & 50.6 & 56.8 & 60.7 & 65.3 & 73.1 \\
\hline Supplies & 18.6 & 20.1 & 25.2 & 24.7 & 26.7 & 28.5 \\
\hline Scholarships & 3.9 & 4.3 & 4.3 & 5.3 & 6.2 & 6.2 \\
\hline Interest ${ }^{i}$ & 17.6 & 14.5 & 13.8 & 11.7 & 14.0 & 16.0 \\
\hline O-her cursent expenditure & 46.6 & 47.6 & 67.6 & 65.4 & 81.1 & 75.5 \\
\hline Capital expenditure. PESAP, VDP, and NP3 2 & 157.1 & 166.8 & 160.9 & 196.1 & 201.7 & 218.0 \\
\hline Capital expenditure & $1 \$ 2.1$ & 161.6 & 156.4 & 194.1 & 199.8 & 217.1 \\
\hline Externally tinanced & 133.5 & 1.37 .3 & 127.5 & 149.4 & 147.4 & 157.1 \\
\hline Equipment and irvestment & 18.6 & 24.3 & 31.9 & 44.7 & $\$ 2.3$ & 60.0 \\
\hline TPSSAT' & 2.3 & 2.5 & $2 \therefore$ & 2.0 & 2.0 & 0.9 \\
\hline Volunlary depa:ture program (VDP) & 0.3 & 0.0 & 0.6 & 0.0 & 0.0 & 0.0 \\
\hline National Pact (NP) & 2.4 & 2.7 & 1.8 & 0.0 & 0.0 & 0.0 \\
\hline Special furcs and ancexed budgets & 16.6 & 20.9 & 21.8 & 23.2 & 24.8 & 24.4 \\
\hline \multirow[t]{2}{*}{ Net lending } & -19.0 & $-\because 6.6$ & -5.2 & -3.6 & -2.2 & -2.5 \\
\hline & \multicolumn{6}{|c|}{ (Arnual pereentage change) } \\
\hline Expenditure ard net lendir.g & 8.6 & 8.6 & 8.9 & $11:$ : & 8.9 & 5.2 \\
\hline Bulgetary expenditure & 8.7 & 4.1 & 8.1 & 10.7 & 8.5 & 5.7 \\
\hline Current experditure & 2.0 & 1.8 & 22.3 & 3.1 & 15.1 & 3.1 \\
\hline Personnel & 7.9 & 5.5 & 12.2 & 6.9 & 7.6 & 11.9 \\
\hline Supplies & 31.0 & 8.1 & 254 & $-1,8$ & 7.9 & 6.7 \\
\hline Scholarships & -7.1 & 10.3 & 0.0 & 23.3 & 16.2 & 0.6 \\
\hline Odter expenditure & 2.9 & 2.1 & 42.1 & -3.3 & 24,0 & -6.9 \\
\hline Capital expenditure, PESAP, VDP, and NP3 2 & 15.3 & 6.2 & -3.5 & 21.9 & 2.9 & 8.1 \\
\hline Capital cxpenciture & 18.2 & 6.2 & -3.2 & $2-1.1$ & 2.9 & 8.7 \\
\hline Exlemially Eisanced & 16.1 & 28 & -9.3 & 20.0 & -1.3 & 6.5 \\
\hline Equipmen; and investment & 35.8 & 30.6 & 31.3 & 40.1 & 17.1 & 14.7 \\
\hline \multirow[t]{2}{*}{ Special funds and annexed budgets } & 28.3 & 26.0 & 4.4 & 6.4 & 6.8 & $-\therefore 6$ \\
\hline & \multicolumn{6}{|c|}{ (Ir percent of tolal budgetary expendivare) } \\
\hline Current experditure & 46.2 & 45.1 & 51.0 & 46.1 & 48.9 & 47.8 \\
\hline 'ersotrel & 16.4 & 16.7 & 17.3 & 16.7 & 16.5 & 17.5 \\
\hline Supplies & 6.4 & 6.5 & 7.7 & 6.8 & 6.8 & 6.8 \\
\hline Scholatships & 1.3 & 1.4 & 1.3 & 1.5 & 1.6 & 1.5 \\
\hline Other expenditure & 16.0 & 15.7 & 20.6 & 180 & 20.5 & 18.1 \\
\hline Capital expenditure, PESAP, VDP, and $\mathrm{NP}^{2}$ & 53.8 & 54.9 & 490 & $5 \vdots 9$ & 511 & 52.2 \\
\hline Capita. expenditure & 52.1 & 53.2 & 47.6 & 53.3 & 50.6 & 52.0 \\
\hline Fixternally sinanced & 45.8 & 15.2 & 37.9 & 41.1 & 37.3 & 37.6 \\
\hline Equipruen: and investment & 64 & 8.0 & 9.7 & $\therefore 2.3$ & 13.2 & 14.4 \\
\hline PESAP, VDP, anc NP & 1.7 & 1.7 & 1.4 & 0.5 & i]. 5 & 0.2 \\
\hline
\end{tabular}


Table 19. Mali: Government Expenditure, 1995-2000 (concluded)

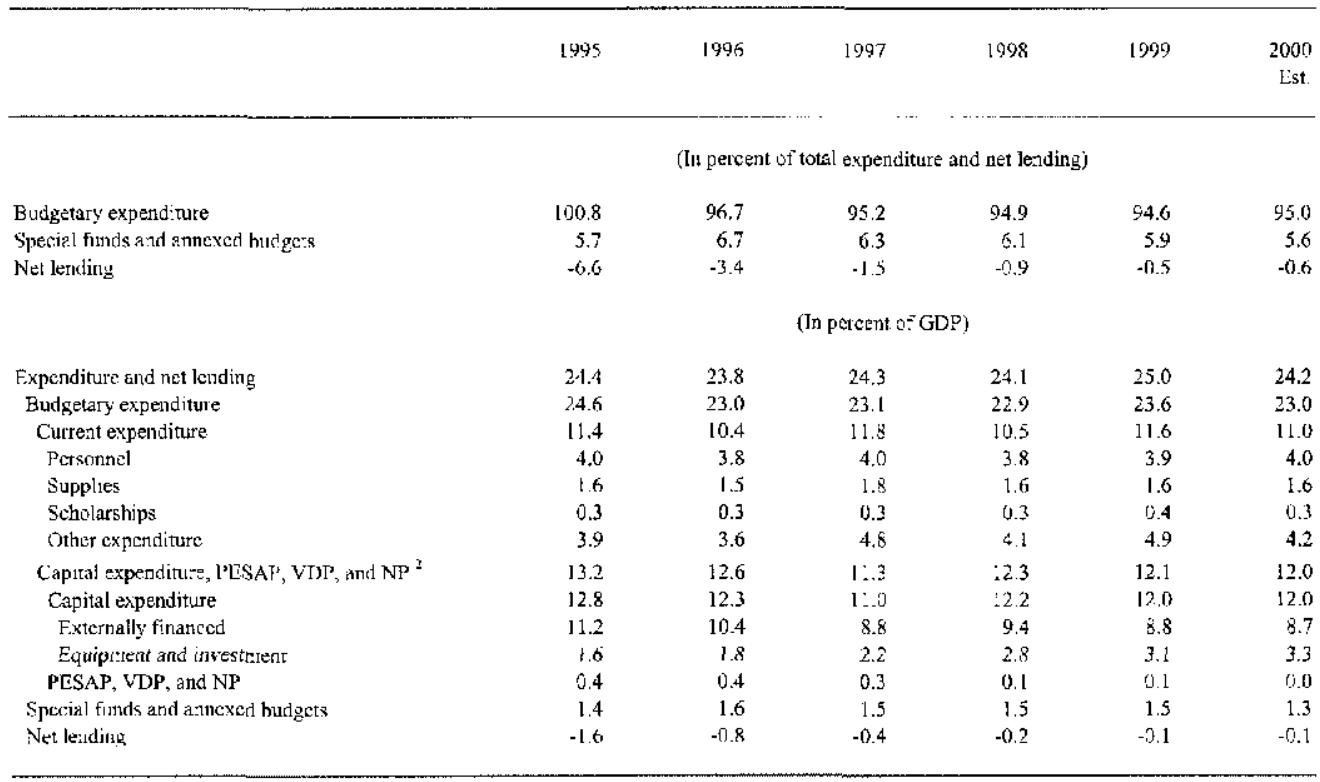

Sources: Malian authoriates: ard Fund staff estiruates

'Schediled; after debt canccllation obtained throug' 1293.

${ }^{2}$ PESAP, Public Eriterprise Sec:or Adjustment Program, finarced by the Wor i Ban's and cofinareiers. 
Tahle 20. Mali: Functional Classification of Budgetary Expendiures, $1995-2000$

(Un millions or CFA francs)

\begin{tabular}{|c|c|c|c|c|c|c|}
\hline & 1995 & 1996 & 1997 & 1998 & 1999 & 2000 \\
\hline Tolal expendilure & 286,800 & 298,700 & 324,100 & 361,942 & 393,010 & 416,400 \\
\hline Current expenditure & 134,700 & 137,100 & 167,700 & 167,820 & 193,240 & 199,300 \\
\hline General public services & 21,861 & 24,018 & 25,432 & 29.796 & 39,761 & 45,725 \\
\hline Detense & 24,689 & 25,267 & 28,337 & 29,298 & 32,674 & 37.575 \\
\hline Educalion & 26,660 & 29,520 & 32,420 & 35,340 & 40,460 & 46,430 \\
\hline Healih & 8,700 & 9,360 & 11,130 & 13,300 & 12,200 & 18,290 \\
\hline Social services & $3,54 i$ & 4,079 & 4,463 & 5,220 & 0.210 & 7,142 \\
\hline Economic services & 18,210 & 19,328 & 21,891 & 20,670 & 22,751 & 26,164 \\
\hline Other & 31,039 & 25,528 & 44,027 & 34,196 & 39,184 & 17,975 \\
\hline Of which: interest on public deb & 17,600 & $i 4,500$ & 13,800 & 11.700 & 14.000 & 36,000 \\
\hline Capital expenditure & 152,100 & 161,600 & 156,700 & 194,122 & 199,770 & 217,100 \\
\hline General public services & 4,820 & 15,253 & 10,459 & 3,469 & 9,789 & 11,257 \\
\hline Deferse & 2,227 & 1,835 & 2,967 & 2,920 & $3: 297$ & 3.742 \\
\hline Fducation & 6,280 & 9,290 & 10,360 & 10,260 & 18,450 & 18,500 \\
\hline Health & 10,160 & 13,640 & 10,600 & 6,920 & 6,120 & 7,000 \\
\hline Social services & 8,644 & 8,809 & 7,286 & 8.143 & 11,605 & 13,316 \\
\hline Economic services & 78,616 & 106,600 & 105,107 & 145,375 & 134,666 & 154,866 \\
\hline Other & 41,353 & 6,173 & 9,621 & 12,035 & 15,843 & 8,339 \\
\hline
\end{tabular}

Soures: Malian authorities; and Fund stalf estimutes. 
Table 21. Mali: Consolidated Operations of the Special Funds and the Annexed Budgets, 1995-2000

(In billions of CF $\wedge$ francs)

\begin{tabular}{|c|c|c|c|c|c|c|}
\hline & 1995 & 1996 & 1997 & 1998 & 1999 & 2000 \\
\hline Revenue & 16.6 & 20.9 & 21.8 & 23.2 & 24.8 & 24.4 \\
\hline Sexial Sccurity Fund (NNPS) & $: 5.0$ & $19 . !$ & 20.1 & 21.5 & 22.9 & 22.5 \\
\hline Other revenue ${ }^{1}$ & 1.6 & 1.8 & 1.7 & 1.7 & 1.9 & 1.8 \\
\hline Expenditure andi net lenting & 16.6 & 20.4 & 21.8 & 23.2 & 24.8 & 24.4 \\
\hline Sacial Securily Fund (NPS) & 15.0 & 14,1 & 20.1 & 21.5 & 22.9 & 22.5 \\
\hline Other expendituret & 1.6 & 1.3 & 1.7 & 1.7 & .9 & 1.8 \\
\hline Surplusidetieit & 0.0 & 0.0 & Ü.0 & 0.0 & 0.0 & 0.0 \\
\hline
\end{tabular}

Source: Malian authorities.

${ }^{1}$ [ncluces ri.e National Hoising fund (FNL), (tue Ceitra] Vetuinary Laboratory (LCV), the National Lotttery (LONAMAj. and the National Institute of Research in Public Health (NRSP). 
Table 22. Mali: Government Wage Bill and Employees. 1995-2000

\begin{tabular}{|c|c|c|c|c|c|c|}
\hline & 1995 & 1990 & 1997 & 1998 & 1999 & 2000 \\
\hline $\begin{array}{l}\text { Wagc bill } \\
\text { (in billions of CFA francs) }\end{array}$ & 48.0 & 50.6 & 56.8 & 60.7 & 65.3 & 73.1 \\
\hline $\begin{array}{l}\text { Annual change in wage bill } \\
\text { (in percent) }\end{array}$ & 7.9 & 5.5 & $: 2.2$ & 6.9 & 7.6 & 11.9 \\
\hline $\begin{array}{l}\text { Wage bill } \\
\text { (in percent o: surrent budgetary expenditure) }\end{array}$ & 35.6 & 36.9 & 33.9 & 36.2 & 33.8 & 35.7 \\
\hline $\begin{array}{l}\text { Wage bill } \\
\text { (in pereent of wtal budggetary cxpendifure) }\end{array}$ & 16.4 & 16.7 & 17.3 & 16.7 & 16.5 & 17.5 \\
\hline $\begin{array}{l}\text { Wate bill } \\
\text { (in percent of GDP) }\end{array}$ & 4.0 & 3.8 & 4.0 & 3.8 & 3.9 & 4.0 \\
\hline $\begin{array}{l}\text { Total number of government employees } \\
\text { as of end-Decomher } \\
\text { Of inich: civil servarts }\end{array}$ & $\begin{array}{l}32,527 \\
29,067\end{array}$ & $\begin{array}{l}36,138 \\
31,961\end{array}$ & $\begin{array}{l}37,340 \\
33,235\end{array}$ & $\begin{array}{l}37,661 \\
33,534\end{array}$ & $\begin{array}{l}410,457 \\
34,226\end{array}$ & $\begin{array}{l}43,980 \\
35,458\end{array}$ \\
\hline $\begin{array}{l}\text { Annual change in tot:al government employees } \\
\text { (ii percent) }\end{array}$ & -0.6 & 11.1 & 3.3 & 0.9 & 7.4 & 8.7 \\
\hline
\end{tabular}

Soure: Malian authoritics. 


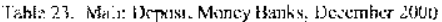

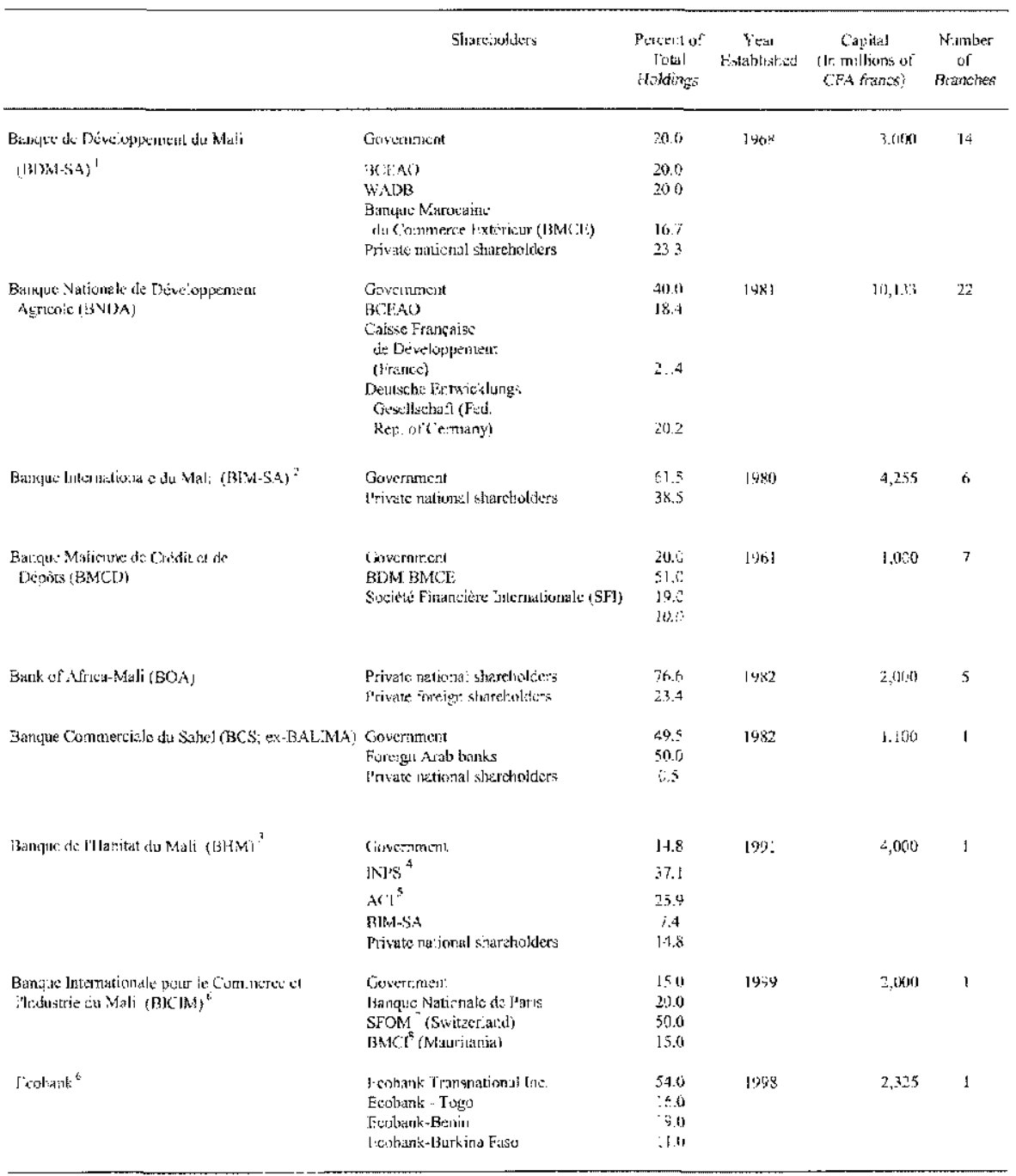

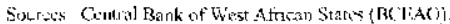

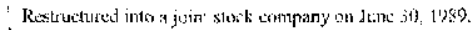

- Forric

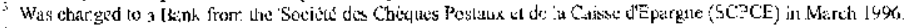

4 irstita: National de Pteqoyance Sociale.

-Agcace Cosson bumodiliere.

"Civeled i.' ] 492

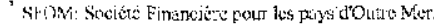

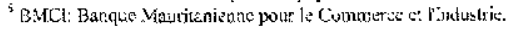


(In billivis of CFS fralck. end of period)

\begin{tabular}{|c|c|c|c|c|c|c|c|c|c|c|c|c|c|}
\hline & \multirow{2}{*}{2995} & \multirow[t]{2}{*}{1996} & \multirow[t]{2}{*}{$199 ?$} & \multirow[t]{2}{*}{1998} & \multicolumn{4}{|c|}{1999} & \multicolumn{4}{|c|}{20 to } & \multirow{2}{*}{$\frac{2(0) 1}{J u a}$} \\
\hline & & & & & Mar. & Jth. & Sep. & Dex. & Mar. & Iun. & Sup. & Des. & \\
\hline forcign 3 ascts inet) ${ }^{2}$ & 147.3 & 190.4 & 183.4 & 150.1 & 174.0 & 155.5 & 101.0 & 113.3 & 199.0 & 179.4 & 112.8 & 167.7 & 197.8 \\
\hline BCEAO & 80.9 & 131.9 & 129.8 & 107.3 & 128.9 & 105.0 & 68.2 & 94.5 & 1.41 .9 & 118.3 & 59.3 & 135.0 & 110.6 \\
\hline 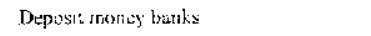 & 60.4 & 58.6 & 53.5 & $4 \div 8$ & 45.1 & 49.6 & 32.8 & 187 & 57.1 & 61.1 & 13.5 & 42.7 & 87.2 \\
\hline Nel domestic assets & 144.1 & 36: & 171.5 & $2\lfloor\overline{7} .1$ & 267.5 & 264.8 & 292.9 & 257.8 & 242.5 & 240.9 & 278.4 & 250.6 & 2644 \\
\hline Orituich: BCEAO? & 50.8 & 34.3 & 29.2 & 42.2 & 57.8 & 66.4 & 82.4 & 71.3 & 58.3 & 64.5 & 83.4 & 75.4 & 87.6 \\
\hline ('redit to the gu)vernment (net) & 16.6 & -23.7 & -23.9 & -26.0 & -14.6 & -6.3 & 0.7 & -221 & -1.7 & 15.6 & -5.4 & .37 .5 & -259 \\
\hline Central bank ${ }^{4}$ & 534 & 26.7 & 29.2 & 42.2 & 57.8 & 66.4 & 82.4 & 71.3 & 57.8 & 66.3 & 53.9 & 75.4 & 87.6 \\
\hline Col:-mercial tranks & -353 & $-x$ & $-48,6$ & $-\dot{n} 4.2$ & $66 . ;$ & -67.0 & -77.2 & -883 & -54.3 & -45.0 & -88.1 & -112.0 & -112.3 \\
\hline Oher & -1.5 & -2.0 & -4.5 & -4.6 & -5.2 & -5.7 & -5.9 & -51 & -5.2 & -5 & -1.7 & -t. 4 & -1.2 \\
\hline Credit to the economy & 131.1 & 173.2 & 2000.4 & 255.0 & 289.7 & 276.1 & 293.9 & 291.6 & 284.5 & 270.3 & 275.8 & 28.4 .5 & 281.7 \\
\hline (H.zer i:cms (net) & -7.6 & -13.4 & -5.0 & -11.8 & -8.1 & -4.9 & -0.3 & -11.7 & -40.3 & .45 .0 & 8.1 & 3.6 & 8.7 \\
\hline Madium- and longutenn exterral liabilitite & -8.9 & -10.3 & -110 & $-\$ .1$ & -12.1 & -11.5 & -11.5 & .71 & -12.1 & .11 .5 & .11 .5 & -16.9 & -10.2 \\
\hline Revaluation accoutnt & 1.1 & 1.1 & $€ .1$ & 1.1 & 5 & 1,0 & 1.6 & 11 & 1.0 & 1.0 & l.t & 1.0 & $\therefore .0$ \\
\hline IST:AOAO & 4.1 & $4 .:$ & 4.1 & 4.1 & 4.0 & $4 . r^{1}$ & 4.0 & $\angle 1$ & 4.0 & +0 & 4.0 & 4.9 & 4.0 \\
\hline Dejosit moley banks & -3.0 & -3.0 & -30 & $-3,0$ & -3.2 & -3.0 & $-3 . i !$ & $-i 0$ & -3.13 & -30 & -1.11 & $\therefore 0$ & -30 \\
\hline Money sup:ly (Ma) & 283.6 & 317.3 & 345.0 & 360.2 & 430,4 & 109.9 & 383.3 & 365.0 & 430.1 & 409.8 & 380.7 & $\therefore 98.5$ & 453.0 \\
\hline Cunrncy in circulation & 107.4 & 120.4 & 129.5 & 135.3 & 160.5 & 155.2 & 132.5 & 123.7 & $: 60.5$ & 155.1 & 123.0 & 148.1 & 148.2 \\
\hline Bank deposits & 175.2 & 1909 & 215.5 & 224.3 & 269.9 & 254.7 & 250.8 & 241.3 & 26194 & 2.54 .7 & 3176 & $260+$ & 394.4 \\
\hline
\end{tabular}

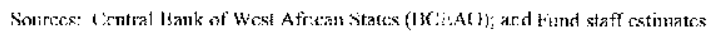

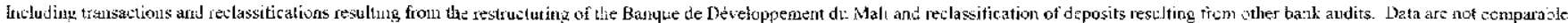
with the previous RFD tabies for 1990 as these were adjusted to a 1987 acciun: ng sase to provide comparaisility with previous yesrs.

Exehtding S.XK a:locations and medium-and lon a-term liabilities.

"Defined as hase morey minus net forcigr: assets

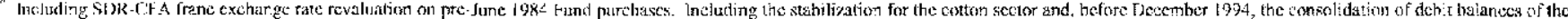

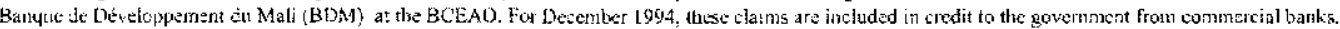

"Ineluding nonstatutery advance to the treasury resulfing trom the consolidation of the fenner central bank's debt of CFiAl 41.8 billion, inclading interest therton.

\section{(CInternational Monetary Fund. Not for Redistribution}


Table 25. Mali: Summary Accounts of the Central Bank, 1995-2001

(ln billiuns of CFA irancs; end of periud)

\begin{tabular}{|c|c|c|c|c|c|c|c|}
\hline & 1995 & 1996 & 1997 & 1998 & .999 & 2000 & $\begin{array}{r}2001 \\
\text { Jum. }\end{array}$ \\
\hline Foreign assets (net) & 80.9 & 131.9 & 129.8 & 107.3 & 94.5 & 125.0 & 110.6 \\
\hline Assets & 158.6 & 226.0 & 248.3 & 228.6 & 227.8 & 258.2 & 240.0 \\
\hline T.jabulitics ' & -77.7 & -94.1 & -118.5 & -121.3 & -133.2 & $\therefore 33.2$ & -129.4 \\
\hline Net domestic assets & 50.8 & 34.3 & 25.5 & 38.0 & 63.7 & 55.6 & 70.0 \\
\hline Clains on the government (net) & 53.4 & 26.7 & 29.2 & 42.2 & 71.3 & 75.4 & 87.6 \\
\hline Claims & 80.5 & 90.3 & 99.8 & 105.9 & 112.9 & 108.9 & 102.7 \\
\hline Of which: Consolidated claims ${ }^{2}$ & 4.7 & 3.1 & 0.0 & 4.2 & 3.7 & 3.0 & 2.9 \\
\hline Liabilities ${ }^{3}$ & -27.1 & -63.6 & -70.6 & -63.7 & -41.6 & -33.5 & -15.1 \\
\hline Othet items (net) & -2.6 & 7.5 & -3.7 & -4.2 & -7.6 & -19.8 & -17.7 \\
\hline Of which: Revaluation account & 4.1 & 4.1 & 4.1 & 4.1 & 4.1 & 4.1 & 4.1 \\
\hline Claims on deposit money banks (net) & -20.2 & -30.0 & -32.9 & -18.0 & -49.4 & -71.5 & -67.4 \\
\hline Claims & 0.0 & 0.0 & 0.17 & 0.0 & 0.0 & 0.0 & 0.0 \\
\hline Advances to moncy market & 0.0 & 0.0 & 0.10 & 0.0 & 0.0 & 0.0 & 0.0 \\
\hline Rediscounts and other advances & 0.0 & 0.0 & 0.0 & 0.0 & 0.0 & 0.0 & 0.0 \\
\hline Liabilities & 20.2 & 30.0 & 32.9 & 18.0 & 49.4 & 71.5 & 67.4 \\
\hline Other deposits & 10.9 & 19.4 & 21.6 & 10.4 & 38.1 & 56.2 & 52.0 \\
\hline Currency held by bankș & 6.9 & 10.6 & 11.3 & 7.5 & 11.3 & 15.3 & 15.4 \\
\hline Other deposits & $\ldots$ & 0.6 & 0.4 & 0.4 & 0.4 & 0.6 & 0.4 \\
\hline Currency outside banks & 107.4 & 120.4 & 129.5 & 135.3 & 123.7 & 148.1 & 148.2 \\
\hline
\end{tabular}

Sutrces: Central Bank of West African Stafes (BCEAO); ard fund staff estimates.

1 Facluding SDR counterpart.

'These clams were securitized and sold to Malian commercial banks in $I 9 \% 4$

${ }^{3}$ Including cash held by the treasury. 
Table 26. Mali: Summary Accounts of the Deposit Money Banks, 1905-2001 '

(in billione of CFA lianes: enci of period)

\begin{tabular}{|c|c|c|c|c|c|c|c|}
\hline & 1995 & 1996 & 1997 & 1998 & $: 999$ & 2000 & $\begin{array}{c}2001 \\
\mathrm{~J} / 1 .\end{array}$ \\
\hline Foreiglo assers (net) & $(6.4$ & 58.6 & 53.5 & 42.8 & $: 8.7$ & 42.7 & $\$ 7.2$ \\
\hline Assets & 74.8 & 71.6 & 70.4 & 70.4 & 76.2 & 98.8 & $1,38.9$ \\
\hline Liabilities & -84 & -13.0 & -16.9 & -27.6 & -57.4 & -56.1 & -51.7 \\
\hline Nel dmenestic asse1s & 115.7 & 135.3 & 159.0 & 179.1 & 2.9 .6 & 214.6 & 214.7 \\
\hline Claims on the gover:ment (net) & -35.3 & -48.4 & -48.6 & -64.2 & .88 .3 & -112.0 & -112.3 \\
\hline Claim: & 19.0 & 23.1 & 39.6 & 13.8 & 14.0 & 17.8 & 17.9 \\
\hline Deposits & -54.3 & -71.5 & -68.2 & -78.0 & -102.3 & -129.8 & -130.2 \\
\hline Cradit to the privale sectur ${ }^{2}$ & 131.1 & 171.2 & 195.9 & 251.0 & 286.5 & 283.6 & 280.9 \\
\hline Crop credit & 4.6 & 2.9 & 1.0 & 12.2 & 15.6 & 18.6 & 1.8 \\
\hline Other & 126,5 & 168.3 & 194.9 & 238.8 & 270.9 & 265.1 & 279.0 \\
\hline Reserves & 20.2 & 30.0 & 32.9 & 18.0 & 49.4 & 71.5 & 67.4 \\
\hline Money matkel position (nel) & 2.4 & 0.0 & 0.0 & 0,0 & 0.0 & 0.0 & 0.0 \\
\hline Deposits & 2.4 & 0.0 & 0.0 & 0.0 & 0.0 & 0.0 & 0.0 \\
\hline Advanes & $0, !$ & 0.0 & 0.0 & 0.0 & 0.0 & 0.0 & 0.17 \\
\hline Other reserves & 17.8 & 30.0 & 32.9 & 180 & 49.4 & 71.5 & 674 \\
\hline Currency holdings & $6 . \hat{9}$ & 10.6 & 11.3 & 7.5 & 11.3 & 15.3 & 15.4 \\
\hline Deporits at eentral hank & 10.9 & 19.4 & 21.6 & 10.4 & 38.1 & 56.2 & 520 \\
\hline Othe: items (net) & $-\{1,3$ & -17.4 & -21.2 & -25.6 & -28.0 & -28.5 & -21.2 \\
\hline Retraluation aciounl & -3.0 & -3.0 & -3.0 & -3.0 & -3.0 & -3.0 & -3.0 \\
\hline Deposits & 176.2 & 196.9 & $2: 5.5$ & 224.9 & 241.3 & 260.3 & 304,9 \\
\hline Denland & 90.5 & 119.4 & 26.5 & 122.2 & 135.5 & 143.5 & 190.5 \\
\hline Time & 85.7 & 77.5 & 89.0 & 102.7 & 105.8 & 116.8 & 114.4 \\
\hline
\end{tabular}

Sources: Central Bank of West African States (BCEAO): and Fund stafí estimates.

Including transactions and adjustrents resulting from the testnucturing of the Banque de Développement du Mali (RDM), and reclassifications of deposits resulting from other bank audits. 
Table 27. Mali: Claims on the Grovenment, 1995-2001

(In bilions of CFA frarcs; enct of period)

\begin{tabular}{|c|c|c|c|c|c|c|c|}
\hline & 1995 & 1996 & 1997 &., 998 & 1994 & 2000 & $\begin{array}{r}2001 \\
\text { Ju1. }\end{array}$ \\
\hline Central bank, net claims & 53.4 & 26.7 & 29.2 & 42.2 & 71.3 & 75.4 & 87.6 \\
\hline Claims & 80.5 & 90.3 & 99.8 & 105.9 & 112.9 & 108.9 & 102.7 \\
\hline Treasury overdmaft & 0.0 & 0.0 & 0.0 & 0.0 & 0.0 & 0.0 & 0.0 \\
\hline lrust Fund on-lent & 0.0 & 0.0 & 0.0 & 0.0 & 0.0 & 0.0 & 0.0 \\
\hline IMF credil un-lent & 758 & 87.3 & 49.8 & 101.8 & 109.2 & 1059 & 99.4 \\
\hline Consolidated clains: ${ }^{2}$ & 4.7 & 3.1 & 0.0 & 4.2 & 3.7 & 3.0 & 2.9 \\
\hline Liabilities & 27.1 & 63.6 & 70.6 & 63.7 & 41.6 & 33.5 & 15.1 \\
\hline Treasury curlency holdings & 5.2 & 6.6 & 7.6 & 8.7 & 7.5 & 5.8 & 6.1 \\
\hline Government deposi1s & 21.9 & 57.0 & 63.0 & 55.3 & 34.0 & 27.7 & 9.0 \\
\hline Deposit mocey banks, net clains & -35.3 & .48 .4 & -48.6 & -64.2 & -88.3 & -112.0 & -112.3 \\
\hline Claims ${ }^{?}$ & 19.0 & 23.1 & 196 & $13 . \hat{x}$ & 14.0 & 17.8 & 17.9 \\
\hline Liabilities & 54.3 & 71.5 & 68.2 & 78.0 & 102.3 & 129.8 & 130.2 \\
\hline Counterparts & -1.5 & -2.0 & -4.5 & -4.0 & -5.3 & -0.9 & -1.3 \\
\hline $\begin{array}{l}\text { Customs duty bills held by the } \\
\text { treasu:y }\end{array}$ & 1.5 & 2.0 & 4.5 & 4.5 & 51 & 0.9 & 1.3 \\
\hline Net ciaims on the government & 16.6 & -23.7 & -23.9 & -26.0 & -22.1 & -37.5 & -25.4 \\
\hline Of which: banking system ${ }^{3}$ & 18.1 & -21.7 & -19.4 & -22.0 & -17.0 & -36.6 & -24.7 \\
\hline
\end{tabular}

Sources: Central Bank of West African States (BCEAO); and Fund staff estimates.

Including transactions and adjustnencs restuting fron the restructuring of the Banguc de Déve:oppement du Mali (BDM), and reclassifieations of deposits resulting from other bank audits.

${ }^{2}$ The consolidated debit batances of the BDM at the BCEAO were securitized in 1994 and for 1994 are inchded in claims of the deosit money banks on the goverankent.

if tge deposit money banks on the government.

${ }^{3}$ Includes the cotton stabilization fund. 
Table 28. Mali: Foreign Assets and Liabilities of the Banking System, 1995-2001

(In billions of CFA francs; end of period)

\begin{tabular}{|c|c|c|c|c|c|c|c|}
\hline & 1995 & 1996 & 1997 & 1998 & 1999 & 2000 & $\begin{array}{r}2001 \\
\text { Jwn. }\end{array}$ \\
\hline Ranking system (net) $^{\prime}$ & 126.4 & 190.4 & 183.4 & 150.1 & 113.3 & 167.7 & 249.5 \\
\hline Foreign assets & 233.4 & 297.5 & 318.8 & 299.0 & 303.9 & 357.0 & 378.9 \\
\hline Foreign liabilities & 107.0 & 107.1 & 135.4 & 148.9 & 190.7 & 189.3 & 129.4 \\
\hline Central bank (net) & 68.9 & 131.9 & 129.8 & 107.3 & 94.5 & 125.0 & 110.6 \\
\hline Foreign assets & 158.6 & 226.0 & 248.3 & 228.6 & 227.8 & 258.2 & 240.0 \\
\hline Foreign exchange & 151.4 & 219.2 & 241.3 & 221.4 & 220.1 & 261.5 & 238.9 \\
\hline Special drawing rights & 0.2 & 0.2 & 0.0 & 0.0 & 0.3 & 0.1 & 0.2 \\
\hline Rescrve position in the fund & 7.0 & 6.6 & 7.0 & 7.1 & 7.3 & 8.4 & 8.3 \\
\hline Fore:gn liabilities & 89.7 & 94.1 & $11 \overline{8} .5$ & 121.3 & 133.2 & 133.2 & 129.4 \\
\hline Lise of Fund resources & 76.6 & 85.8 & 103.5 & 107.4 & 117.9 & 128.3 & 118.6 \\
\hline Trust Fund & 0.0 & 0.0 & 0.0 & 0.0 & 0.0 & $0.1)$ & 0.0 \\
\hline SDR's allocations & 12.0 & 11.8 & 12.8 & 12.7 & 1.3 .4 & 15.2 & 14.9 \\
\hline Other lizbilities & 1.1 & -3.5 & 2.2 & 1.2 & 2.0 & -10.3 & -4.1 \\
\hline Deposit money banks (nct) & 57.5 & 58.6 & 53.5 & 42.8 & 18.7 & 42.7 & 138.9 \\
\hline Foreign assets & 74.8 & 71.6 & 70.4 & 70.389 & 76.2 & 98.8 & 138.9 \\
\hline Foreign liabilities & 17.3 & 13.0 & 16.9 & 27.6 & 57.4 & 56.1 & 0.0 \\
\hline Short term & 8.4 & 6.9 & 5.9 & 19.5 & 50.3 & 45.2 & 0.0 \\
\hline Medium and long term & 8.9 & 6.1 & 11.0 & 8.1 & 7.1 & 10.9 & 0.0 \\
\hline
\end{tabular}

Sources Central Bank of West Airican States (BCEAO); and Fund staff estimates.

'Differs from ret forcigr assets in Table 24, which exchude medium- and long-term foreign liabilities. 
Table 29. Mali: Interest Rate Indicators, 1995-2001

(In percent per year)

\begin{tabular}{|c|c|c|c|c|c|c|c|}
\hline & 1995 & 1996 & 1997 & 1998 & 1999 & 2000 & $\begin{array}{r}2001 \\
\text { JuIl. }\end{array}$ \\
\hline \multicolumn{8}{|l|}{ Interest rates } \\
\hline Deposits & 5.75 & 5.00 & 4.50 & 1 & 了 & 1 & 1 \\
\hline Rediscount rate & 7.50 & 6.50 & 6.00 & 6.25 & 5.75 & 6.50 & 6.50 \\
\hline Moncy marke & 5.75 & 5.00 & 4.50 & 4.95 & 4.95 & 4.95 & 4.95 \\
\hline Savings deposits & 4.50 & 3.50 & 3.50 & 3.50 & 3.50 & 3.50 & 3.50 \\
\hline
\end{tabular}

Sources: Malian authorities; IMF, Intemational Financial Statistics; and Fund staff estimates.

${ }^{1}$ Frcely deternined by commercial banks. 
Table 30. Mali: Central Bank Rediscount Rates,

October 1993-September 2001 ${ }^{1}$

(In pereent per year)

Date

Discount

Rate

October 18, 1993

12.50

December 20, 1993

10.50

January 18,1994

14.50

June 27, 1994

12.00

August 1, 1994

11.00

August 29, 1994

10.00

September 5, 1994

10.50

January 23,1995

9.00

June 5, 1995

8.50

1)ecember 26, 1995

7.50

August 5, 1996

7.25

August 19, 1996

7.00

October 21, 1996

6.50

February 17, 1997

6.25

Septenther 8, 1997

6.00

August 31, 1998

6.25

January 4, 1999

5.75

Junc 19, 2000

6.50

September 30, 2001

6.50

Source: Central Bank of West African States (BCEAO).

${ }^{1}$ Rates applied to shori-term credit of one year or less and to medium-term credit of up to ten years. The BCEAO will also rediscount long-term credit that, at the time of rediscounting, has no more than 15 years to maturity. 
Table 31. Mali: Interest Rates Applied in the Money

Market, March 1995-September 200! '

(In percent per year)

Date

lnterest

Rate

1995

March

5.50

Juine

5.50

September

5.50

Decentuer

5.78

1996

March

lune

Seplember

Docember

1997

March

Iune

September

5.02

December

4.96

1998

March

June

1999

March

June

September

December

2000

Mareh

June

Seplember

2001

Marcl]

Source: Central Bank of West African States (BCEAO).

'In October 1993, the money market was transformed into an auction of weekly advances. Figures showl are monlhly ayerages. Rates paid on auctions of central bank bills, inlroduced in August 1996, are not included 
Table 32. Mai: Maximum Leiding Rates Applied by Conunercial Bariks, 1995 - 2001

(In percenl ner yegrI]

\begin{tabular}{|c|c|c|c|c|c|c|c|c|c|c|c|c|}
\hline & $\begin{array}{r}\text { Jun. } 23 \\
1445\end{array}$ & $\begin{aligned} \text { Jin. } 5 \\
\text { lyys }\end{aligned}$ & $\begin{array}{r}\text { Dec. } 26 \\
1495\end{array}$ & $\begin{array}{r}\text { Aug. } 5 \\
1996\end{array}$ & $\begin{array}{r}\text { Aug. } 19 \\
1946\end{array}$ & $\begin{array}{r}0 \text { Oct. } 21 \\
1996\end{array}$ & $\begin{array}{r}\text { Fch. } 17 \\
1997\end{array}$ & $\begin{array}{r}\text { Scp. } 8 \\
1997\end{array}$ & $\begin{array}{l}\text { Sep. } \\
1998\end{array}$ & 1999 & 2000 & 2001 \\
\hline \multicolumn{13}{|l|}{ Short- and medium-term credit } \\
\hline Crop finascing axd export credit & 18.0 & 17.0 & 15.0 & 14.5 & 14.0 & 13.0 & 12.5 & 12.0 & 18.0 & 18.0 & 18.0 & 18.0 \\
\hline $\begin{array}{l}\text { Firaxing of storege of } \\
\text { agricultivel products }\end{array}$ & 18.0 & 17.0 & 150 & 14.3 & 14.1 & 12.0 & 12.5 & 12.0 & 18.11 & 180 & 180 & 18.0 \\
\hline $\begin{array}{l}\text { Credit to small and mediutw- } \\
\text { sized national enterprises }\end{array}$ & 18.0 & 17.0 & 15.0 & 14.5 & 14.0 & 13.0 & 12.5 & 12.0 & 18.0 & 18.0 & 18.0 & 18.0 \\
\hline \multicolumn{13}{|l|}{$\begin{array}{l}\text { Credit to nution:ls' for } \\
\text { construction of tirst }\end{array}$} \\
\hline primary residence & 18.0 & 17.0 & $15.1)$ & 14.5 & 14.0 & 1.3 .0 & $12 . .5$ & 12.0 & 18.0 & 180 & 18.0 & 18.0 \\
\hline Other crexlits & 18.0 & 170 & 15.0 & 14.5 & 14.0 & 13.0 & 12.5 & 12.0 & 18.0 & 18.0 & 18.0 & 18.0 \\
\hline \multicolumn{13}{|l|}{ Lung-kima sredit ${ }^{2}$} \\
\hline $\begin{array}{l}\text { Cradit to small and nedium- } \\
\text { sized national enkrprises }\end{array}$ & 18.0 & 17.6 & 15.0 & 14.5 & 14.0 & 130 & 12.5 & 12.0 & 180 & 160 & 180 & 18.6 \\
\hline \multicolumn{13}{|l|}{$\begin{array}{l}\text { Credit to nationals' for } \\
\text { construction of first }\end{array}$} \\
\hline plimary residence & 18.0 & 17.0 & 15.0 & 14.5 & 14.0 & 13.0 & 12.5 & 12.11 & 18.0 & $18.0]$ & IE. 0 & IX.iI \\
\hline Other ereilis & 18.0 & 17.0 & 15.0 & 14.5 & 14.0 & 13.0 & 12.5 & 12.0 & 18.0 & 18.0 & 18.0 & 18.0 \\
\hline
\end{tabular}

Source: Central bank of West African States (BCEAO).

'OC any mentur state of the West African Monetury Union (WNML).

${ }^{2}$ With maturity of more ther 2 years and less then 15 years. 


\begin{tabular}{|c|c|c|c|c|c|c|}
\hline & 1945 & $14 \%$ & 1497 & 1 148 & (9y? & 2001 \\
\hline & \multicolumn{6}{|c|}{ (lt: bilions of CFA ftarcs) } \\
\hline Expons, rob. & 2339 & 23.4 & $327 . \bar{i}$ & 331.1 & 351.6 & $37 \times .5$ \\
\hline Getton tiòs & $126 \%$ & 132.6 & $: s k . j$ & $14 i .8$ & 15iJ.1 & $111) .4$ \\
\hline$(\mathrm{i}+k)$ & 350 & $3 ; .8$ & $: 17.2$ & 1331 & $1+2.4$ & 189.4 \\
\hline 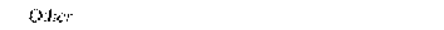 & $810+$ & 47.1 & 51.0 & $50 ?$ & 500 & 79.1 \\
\hline Impons, fo.h. & $.011 ?$ & $-3 x \geq .1$ & $-3 \mathrm{iB.6}$ & -129.3 & -372.8 & -421.4 \\
\hline Trare halances & $-5 / 3$ & his: & $y .1$ & $1 . x$ & -21.2 & $-43,0$ \\
\hline Ea:for service (net) & $-1+7$ & 22.0 & .30 .2 & -300 & -43.2 & $-5 !, 0 !$ \\
\hline ['rivate tralsicm (net) & $5: 0$ & 46.1 & 42.5 & 40.0 & 45.8 & 47.1 \\
\hline (Official tranofesinc:) & $1+2.1$ & $52 . .3$ & $3 ! .1$ & 27.6 & 24,1 & 45.4 \\
\hline Ot which: budigctayy gronty & 29.4 & 26.7 & 20.8 & 19.6 & .4 .6 & $32: 2$ \\
\hline \multicolumn{7}{|l|}{ Curren; accolnt ba ance } \\
\hline Exctuding olficial t:unsiors & -230.3 & $-18 \pm ?$ & -135.3 & .147 .3 & -175.9 & $-21 ? .6$ \\
\hline ixilualng official tranterers & -38.2 & .133 .4 & .164 .2 & -119.7 & .155 .8 & $-1 ? 1.2$ \\
\hline Capital aus liralccisl atceul: & 119.3 & $187 .:$ & 105.3 & $10 \times 3$ & $13 \% .1$ & 20.5 .2 \\
\hline Captial atcoust) (nit) & [3.1) & 706 & 650 & 732 & 64.8 & (P). \\
\hline of which : projicts grants & $\therefore 3.1]$ & this 8 & 6.3 .4 & 70.3 & $6 s .8$ & 64.0 \\
\hline "inass:-inl aso:at? & 30.3 & 116.5 & $40 . .^{3}$ & 35.1 & 6.3 & 130.2 \\
\hline P'rivate (net) & $.46,9$ & 36.3 & -8.6 & -22.9 & 7.0 & 77.8 \\
\hline Official (net) & 83.2 & 82.2 & 49,0 & 58.0 & 60.3 & 61.4 \\
\hline Disbutsements rel & 117,5 & 102.1 & 72.7 & $\$ 3.9$ & 91.7 & 95.0 \\
\hline Budgctary & 47.1 & $3 \cdot .6$ & 11.6 & 18 & 13.1 & 59 \\
\hline Project rclanaj & 70.5 & 6.5 & 61.1 & 79.1 & 78.6 & 88.1 \\
\hline A.nontizalien due un fublic deb: & -79.2 & -60.9 & -30.0 & .25 .9 & -31.4 & .32 .61 \\
\hline Etrors and umssious & -23 & 9.5 & -3.2 & -11.2 & 0.0 & -12.2 \\
\hline Overal: balame & $2 K .8$ & 632 & -20 & -22.6 & -12.7 & 24.7 \\
\hline Financing & 28.8 & 6i. 2 & 20 & 225 & 12.7 & .24 .7 \\
\hline Tionegen ascets (net) & $-2 B S$ & 6.2 & 2.0 & 2.26 & 12.7 & $.27,3$ \\
\hline of astich: I:HF (nct) & 13.4 & 10.0 & 9.9 & 1.6 & 6.9 & -5.7 \\
\hline HIPC Litiantie assictance" & 0.0 & 0.0 & 0.0 & 0.0 & 0.0 & 2,6 \\
\hline Mertstusundum :te:ns: & \multicolumn{6}{|c|}{ (I'creentage erarge) } \\
\hline \multicolumn{7}{|l|}{ Evic:nat trado } \\
\hline Fxports wolume & 14.7 & 0.0 & 17.1 & -0.1 & 17.4 & -2.3 \\
\hline Of which nonming & & & & -11.4 & 21.7 & $.71 \% .8$ \\
\hline Impott: volume & 20.7 & .7 .6 & 3.3 & i.t. & 80 & .1 .5 \\
\hline of which andmining imoort wolutre & i) & 00 & 0.0 & 0.5 & 6.1 & -34 \\
\hline Expert unic vals: & 50 & -11 & 0.6 & 1.1 & 9.6 & III:: \\
\hline Impert unit valus: & 2.4 & $-6 ?$ & 13 & 2.7 & $4 \varphi$ & 15.7 \\
\hline \multirow[t]{2}{*}{ Thers of liade } & $2 \mathrm{f}$ & -6.9 & 3 & 3.3 & $-13 x$ & -4.4 \\
\hline & \multicolumn{6}{|c|}{ (1) jerent of GDP, anless othrowisc indicatedi } \\
\hline \multicolumn{7}{|l|}{ Exlemial currenl accoun: balasec } \\
\hline  & -19.4 & .141 & -3.5 & $-4 . ?$ & -10.8 & -12.0 \\
\hline Irriluciets uficial tisatsfers & .7 .4 & -10.1 & .7 .3 & -7.5 & -9.3 & .9 .5 \\
\hline Exuernal public teos ${ }^{3}$ & 0.0 & 0.11 & 5.0 & 111.8 & 1062 & 104.0 \\
\hline \multicolumn{7}{|l|}{ Jebr-servite ra:io } \\
\hline Before Lubl reliter & 39.2 & 29.4 & $\because n$ & 11.4 & 12.5 & 13.3 \\
\hline 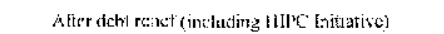 & 55.8 & 44,0 & 0.1 & 11.1 & 12.5 & 12.7 \\
\hline 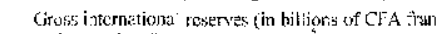 & 158.6 & 226.0 & $248 . .3$ & 228.6 & 227.8 & 269 \\
\hline 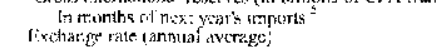 & 4.0 & 5.2 & 5.5 & 1,6 & 1.1 & 4.3 \\
\hline (1) Fandes per suis & 757.2 & $7: 12.7$ & $30,3 .: 1$ & 800.2 & 842.9 & 936.4 \\
\hline CFA Tranes per ij.s dollar & 494.1 & $51 \leqslant f_{4}$ & 583.7 & 590.0 & 615.8 & 7100 \\
\hline \multicolumn{7}{|l|}{ Cotumodity prices: } \\
\hline Pervilenm (crude upol, (US sol ar ner baril) & 17.2 & 20.1 & 19.3 & 13.1 & $18.1)$ & $3 \times ?$ \\
\hline (iesid (U.s. dollas per firco ousuce) & 38.1 .2 & 337.8 & 331.:- & 294.1 & $37 x y$ & 279.2 \\
\hline (cotter (certs por pound. internutional price) & 93.3 & 80.5 & $7 \dot{9} 2$ & 65.5 & 53.1 & 59,0 \\
\hline Cotton (cerfs pes period. Me'jan prise) & & & 60.0 & 63.8 & 199 & 39.4 \\
\hline
\end{tabular}

Souross: Malian aulhor:ties; ard Fund staff estinnates and prolections.

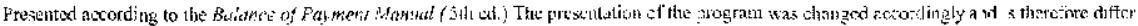
fron die presentation in EBS:09:162, s:11)\%0.

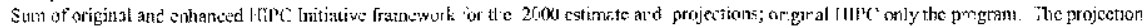

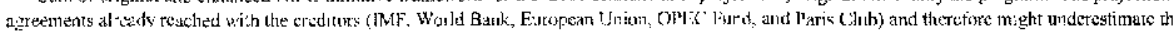
diat Mali wil finally recese.

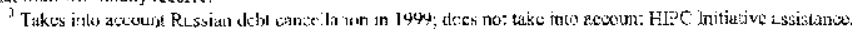

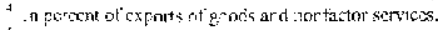

* Goots and nontiach services. 
Toble 34. Mati: Coniposition of I:xoorts, t.u.b., 1995-2000)

(Unless otherwise indicated, values in billions of CFA franes, volt:me in metric tons, and unit values in CF.A franes per kilogram!

\begin{tabular}{|c|c|c|c|c|c|c|}
\hline & 1995 & 1996 & 1997 & 1998 & 1999 & 2000 \\
\hline \multicolumn{7}{|l|}{ C'ntton } \\
\hline Valute & 129.2 & 134.9 & $161 \%$ & 150.5 & 1530 & 112.9 \\
\hline \multicolumn{7}{|l|}{ Cotton :ber } \\
\hline Value & 126.9 & 132.6 & 158.7 & 147.8 & 150.1 & $1](0,0)$ \\
\hline Volurec & $148,122.8$ & $161,053.4$ & $203,158.7$ & $178,032.0$ & 22,2610 & $178,230.6$ \\
\hline Unit value & $8 \leq 6.8$ & 823.3 & $7 \geqq 1.0$ & 830.0 & 677.0 & 617.0 \\
\hline \multicolumn{7}{|l|}{ Corton wkes } \\
\hline Valuc & 0.5 & 0.5 & 0.5 & 0.6 & 0.6 & 0.6 \\
\hline Volume & 11.025 .0 & $11,188.3$ & $11,615.0$ & 1,00000 & $15,420.1]$ & $|:, y i| 1$ \\
\hline Unit value & 43.2 & 44.2 & 44.0 & 45.4 & 451 & 520 \\
\hline \multicolumn{7}{|l|}{ Cotron :hreads and materials } \\
\hline Value & 1.1 & 1.1 & 1.2 & 1.3 & 1.3 & 1.4 \\
\hline Valume & 1.372 .0 & $1,398.0$ & $1,458.0$ & $1,516.3$ & $1,+6 !: 0:$ & 1.396 .3 \\
\hline Unit value & 802.4 & 811.0 & 8니이 & 858.1 & 850.8 & $\$ 81.0$ \\
\hline \multicolumn{7}{|l|}{ Cottonseed oil } \\
\hline Value & 0.7 & $0 . ?$ & 0.8 & 0.9 & 0.3 & $0.1)$ \\
\hline Volume & 3.1310 & $3,149.8$ & $3,276.0$ & $3,5000.6$ & $3,640,0$ & $3,2,11$ \\
\hline Unit value & $22 y .3$ & 229.0 & $2<2.0$ & 249.9 & 247.8 & 285.7 \\
\hline \multicolumn{7}{|l|}{ Livestock } \\
\hline Valtee & 400 & 30.0 & 31.3 & 28.1 & 33.0 & $\$ 4.3$ \\
\hline Volu:ne & $37,582.0$ & $2 \times, 594.0$ & 29.464 .0 & $24,490.0$ & $77,651 .: 1$ & $3,3,18 !, 1:$ \\
\hline Unit value & 1.084 .7 & 1.049 .0 & 1.062 .0 & $1,147.0$ & $1,192.0$ & $1,3,34.7$ \\
\hline \multicolumn{7}{|l|}{ flides and Ieathers } \\
\hline Value & 1.6 & 2.6 & 3.1 & 3.2 & 3.4 & 4)$. \\
\hline Volur:a & $1,672.0$ & 2.861 .0 & 2.976 .0 & $3,124.8$ & $3,231,0$ & $3,-45.1$ \\
\hline Unit value & 957.6 & 925.0 & 1.032 .0 & $1,022,0$ & $1,036.6$ & 1.292 .9 \\
\hline \multicolumn{7}{|l|}{ F:st: } \\
\hline Value & 0.8 & 0.9 & 0.9 & 1.0 & 1.0 & 19 \\
\hline Volune & 302.0 & 870.0 & 896.1 & 876.0 & 902.3 & 929.3 \\
\hline Ur:jt value & 997.5 & 998.0 & $1,050.4$ & 1.084 .7 & 1.075 .0 & $1,081.5$ \\
\hline \multicolumn{7}{|l|}{ Shelled grourdizuts } \\
\hline Value & 0.2 & 0.3 & 0.2 & 0.2 & 0.2 & 0.2 \\
\hline Volume & $1,754.0$ & $2,350.0$ & $1,816,0$ & 1.852 .0 & $1,8 \div 0.0$ & $1,927.8$ \\
\hline Unit value & 113.0 & $1: 3.0$ & $1: 6.0$ & 119.0 & 119.0 & 119.7 \\
\hline \multicolumn{7}{|l|}{ Other vilseeds } \\
\hline Value & 0.1 & 0.3 & 0.3 & 0.3 & 0.3 & 0.3 \\
\hline Volume & 714,0 & $2,142,0$ & 1.850 .0 & 1.869 .0 & $1,8 \pi 7.0$ & $1,906.6$ \\
\hline : Init value & 140.0 & 140.0 & 148.0 & 153.0 & 152.0 & 152.9 \\
\hline \multicolumn{7}{|l|}{ Gold } \\
\hline Va]ue & 35.6 & 39.8 & 117.2 & 133.1 & $: 42,4$ & 189.4 \\
\hline Volume & 6.2 & 6.6 & 18.5 & 22.8 & 25.3 & 28.3 \\
\hline Uni: value & 5.776 .600 .0 & $6,037,782.3$ & $6,340,359.6$ & $5,831.535 .5$ & $5.620,027.3$ & 5.698 .342 .8 \\
\hline \multicolumn{7}{|l|}{ Other } \\
\hline Vaue & l6. 4 & 12.6 & 13.6 & 14.7 & 18.3 & 25.9 \\
\hline Total & 223.0 & 221.4 & 327.7 & 331.1 & 3916 & $3 i 8$. \\
\hline \multicolumn{7}{|l|}{ Memorandun item: } \\
\hline \multicolumn{7}{|l|}{3 principal exports us } \\
\hline a percentage of total exports & 91.5 & 22.5 & 94.5 & 94,1 & 93.1 & 91.6 \\
\hline
\end{tabular}

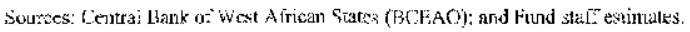




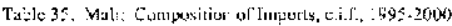

Undess otherwise indicated, values in billione of CFA frantos, volumes in theteic rons, unit values in C'A francs per kilozran)

\begin{tabular}{|c|c|c|c|c|c|c|}
\hline & 1995 & 1946 & 1997 & 1998 & 1999 & 2000 \\
\hline \multicolumn{7}{|l|}{ Foodslufts } \\
\hline Value & 55.4 & 58.0 & 64.7 & 72.8 & 58.9 & 56.3 \\
\hline \multicolumn{7}{|l|}{ Cereals } \\
\hline Value & 10.9 & 12.8 & 12.2 & $: 7.8$ & 15.7 & 9.9 \\
\hline Volume & $49,840.0$ & $58,528.0$ & $59,5000.0$ & $84,500.0$ & $78,9 \div 5,1)$ & $A B, 250,0$ \\
\hline U:ail valut & 218.7 & 218.7 & 205.5 & $2: 0.0$ & 198.9 & 204.9 \\
\hline \multicolumn{7}{|l|}{ Stigar } \\
\hline Value & 168 & 17.2 & 17.6 & 17.1 & 16.9 & 13.4 \\
\hline Volume & 56,4500 & $69,054.5$ & $62, k 57.1$ & $70,71 \leq .0$ & $75,984.11$ & $5 \kappa_{1}, 357.2$ \\
\hline Unit value & $295 \mathrm{u}$ & 272.8 & 280.0 & 241.2 & 221.5 & 237.6 \\
\hline \multicolumn{7}{|l|}{ Muls } \\
\hline Valte & 11.9 & 9.9 & 12.2 & 12.7 & 15.5 & 11.7 \\
\hline volume & $10,258.6$ & 8.497 .9 & 9.363 .0 & $9,456.6$ & $11,465.0$ & 8.598 .8 \\
\hline Jnit value & $1,160.0$ & $1,: 65.0$ &., 303.0 & $1,345.5$ & $1,348.0$ & $1,355.2$ \\
\hline \multicolumn{7}{|c|}{ Tea and zoffec } \\
\hline Value & 2.7 & 5,0 & 8.2 & 11.5 & 8.3 & 9.0 \\
\hline Volume & $1,641.3$ & 3.544 .5 & $4,90 \mathrm{p}, 0$ & $6,850,0$ & $4,999.0$ & 50990 \\
\hline IJnit va'ne & $1,645.0$ & $1,341.0$ & $1.6 ? 0.0$ & $1,6.75 .0$ & 1.652 .9 & 1,7654 \\
\hline \multicolumn{7}{|c|}{ Other heverages } \\
\hline Valuc & 0.7 & 0.8 & 0.9 & 0.9 & 1.2 & 1.2 \\
\hline Volume & $2,622.5$ & 2.701 .0 & $2,782.0$ & $2,837.6$ & 3.681 .0 & 3.754 .6 \\
\hline Lnál vaiue & 256.1 & 252.0 & 306.0 & 316.0 & 317.0 & 318.9 \\
\hline \multicolumn{7}{|l|}{ Cola rutz } \\
\hline Volue & $: .5$ & 1.6 & 1.8 & 1.9 & 2.1 & 2.1 \\
\hline Volume & 8.222 .2 & 8.551 .1 & 8.723 .0 & 8.941 .1 & 9.925 .3 & $10,123.5$ \\
\hline Uritt value & 184.3 & 190.0 & 202.0 & 208.6 & 206.8 & 208.1 \\
\hline \multicolumn{7}{|l|}{ other } \\
\hline Value & 10.9 & 10.7 & 11.9 & {$[1.0$} & 9.4 & 5.1 \\
\hline Volume & $30,783.1$ & 31.706 .5 & $32,568.0$ & $32.894,0$ & 28.468 .0 & 27.329 .3 \\
\hline Unit value & 354.0 & 3780 & 3640 & 335.8 & 329.6 & 331.6 \\
\hline \multicolumn{7}{|c|}{ Macsines and veticles } \\
\hline Value & 123.0 & 115.4 & 125.2 & 128.3 & 154.1 & 178.4 \\
\hline Vilutne & 350600 & $32,140.1$ & $34,340.0$ & $34,734,0$ & $40,951.0$ & $45, j 46.1$ \\
\hline Unit vaiuc & $5,513.1]$ & 3.585 .8 & $3,540,0$ & $3,694.6$ & $3,761,5$ & $3,759.3$ \\
\hline \multicolumn{7}{|c|}{ Jetroleum products } \\
\hline Valuc & 42.4 & 52.2 & 61.1 & 52.0 & 71.0 & 120.4 \\
\hline Volume & 289.905 .0 & $332,843.0$ & $400,164.0$ & 439.2430 & 471.925 .0 & $516,056.7$ \\
\hline Untit va.ue & $: 46.3$ & 156.8 & 152.6 & 118.4 & 150.5 & 233.3 \\
\hline \multicolumn{7}{|c|}{ Coris:ruction raterials } \\
\hline Value & 39.4 & 39.8 & 47.1 & 50.7 & 51.5 & $\$ 3.5$ \\
\hline Volume & $40,000.0$ & $41,000.0$ & $43,472.0$ & $44,9 \leq 00$ & $45,714.0$ & $45,999.9$ \\
\hline Lribl valus & 985.0 & 970.0 & $1,08.30$ & 1,1290 & $1,136.0$ & $1,162.8$ \\
\hline \multicolumn{7}{|c|}{ Chemical procicts } \\
\hline Value & 35.9 & 36.8 & 34.2 & 43.3 & 50.4 & 60.7 \\
\hline Volume & 77.780 .0 & $5: 281.0$ & $84,126,0$ & $87,600,0$ & 95.9:17. & $97.404,0$ \\
\hline Unit value & $4 \$ 3.0$ & 453.0 & 466.0 & 294.0 & 525.0 & 622.6 \\
\hline \multicolumn{7}{|c|}{ 'Texliles andả lcalber } \\
\hline Vahus & 21.7 & 23.3 & 23.7 & 26.6 & 22.4 & 16.5 \\
\hline Volume & $22.5 \mathrm{~J} 0.2$ & 23.410 .6 & $23,700.0$ & $24,174.10$ & $22,422,0$ & $15,695.4$ \\
\hline Unit wite & 965.0 & 995.0 & 998.0 & $1,101.8$ & $1,000.8$ & 1.052 .5 \\
\hline \multicolumn{7}{|l|}{ Otier } \\
\hline Valuc & [1].E & 09.6 & 72.6 & 71.2 & 88.5 & 87.6 \\
\hline Total & +28.7 & $30,5,1$ & 433.5 & $4+8.0$ & 507.2 & 573.4 \\
\hline
\end{tabular}

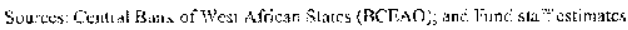


(In millions of U.S. collars)

\begin{tabular}{|c|c|c|c|c|c|c|c|c|c|c|c|c|}
\hline & \multicolumn{2}{|c|}{1995} & \multicolumn{2}{|c|}{1996} & \multicolumn{2}{|c|}{ 19y? } & \multicolumn{2}{|c|}{1993} & \multicolumn{2}{|c|}{1999} & \multicolumn{2}{|l|}{20000} \\
\hline & Valuc & P'ctcentr $^{2}$ & Value & Percent & Valte & Percent & value & Percent & Value: & P:acest & $\begin{array}{r}\text { Value } \\
\text { Est. }\end{array}$ & $\begin{array}{r}\text { Perrent } \\
\text { ES1. }\end{array}$ \\
\hline kiports & 235.9 & $100 . \mathrm{ci}$ & 252.3 & 100.0 & 270.4 & 100.0 & 293.9 & 108.7 & 239.3 & 00.0 & $19<.7$ & 81.4 \\
\hline $\begin{array}{l}\text { Irdustrial coutures } \\
\text { Of which: }\end{array}$ & 91.9 & 39.0 & 1051 & 37.2 & 103.0 & 38.1 & 121.2 & $4<8$ & $\ln 5$ & 42.6 & 99.6 & 41.0 \\
\hline $\begin{array}{l}\text { Of which: } \\
\text { Be:giuin-Luxembovurg }\end{array}$ & .7 .8 & 7.5 & 12.4 & 4.4 & 6.4 & 2.3 & 6.6 & 2.3 & 9.1 & 3.8 & 7.7 & 3.2 \\
\hline Fimuse & 6.9 & 2.9 & 1.9 & 1.8 & 7.0 & 2.6 . & 4.6 & 1.6 & 4.7 & 200 & 4.2 & $\begin{array}{l}3.2 \\
1.8\end{array}$ \\
\hline Germany & 3.7 & i. 6 & 2.9 & 1.0 & 3.8 & 1.4 & 4.7 & 1.7 & 4.3 & i.8 & 13.2 & s.s \\
\hline Spais & 7.8 & 33 & 7.8 & 2.8 & 7.2 & 2.7 & 7.6 & 2.7 & 4.3 & 1.8 & 3.9 & 1.0 \\
\hline United Kingatom & 0.3 & 0.1 & 1.0 & 0.3 & 0.9 & 0.3 & 0.7 & 0.2 & 4.1 & 17 & 92 & is \\
\hline Developing countres & 141.0 & 59.8 & 173.7 & 61.5 & $16 \hat{0} .6$ & (6) 5 & 1683 & 59.6 & 132.8 & 20.2 & 89.7 & 37.5 \\
\hline $\begin{array}{l}\text { Of which } \\
\text { Afrea }\end{array}$ & 20.1 & 8.5 & $27 y$ & 9.9 & 22.0 & 8.1 & 31.6 & 11.7 & 15.8 & 7.0 & 23.9 & la 01 \\
\hline Of whick: Lótce d'soies & 2.9 & 1.2 & 4.2 & 1.5 & 2.8 & 1.1 & 1.9 & 07 & 0.9 & 0.4 & 3.1 & 13 \\
\hline Asia & 97.3 & 41.2 & 137.5 & 487 & 121.9 & 45.1 & 106.5 & 30.4 & 100.3 & 41.9 & 310 & 14.2 \\
\hline ojwhich: Peiples & & & & & & & & & & & & \\
\hline Republic of China' & $33:$ & 14.0 & 12.4 & 4.4 & $25 ?$ & 9.5 & 5.1 & 1.9 & 1.7 & 6.: & 0.5 & 0.1 \\
\hline Others' & 23.6 & icio & 8.3 & 3.0 & 197 & 7.0 & 30.2 & 11.2 & 15.6 & 6.5 & 31.8 & 13.3 \\
\hline Imports & 988.8 & 100.0 & $1,121.1$ & $1: 0.0$ & $1,138.0$ & 101,0 & $1,22 \%, 4$ & 100.0 & 1.264 .7 & 100.0 & 1.312 .1 & $: 33.7$ \\
\hline $\begin{array}{l}\text { Industiall countries } \\
\text { Of whitit }\end{array}$ & 393.1 & $3 \% . x$ & 429.9 & 38.3 & 431.5 & 37.9 & 455.4 & 36.7 & 443.3 & 35.1 & 389.8 & 30.8 \\
\hline Belgium-[unembourg & 33.8 & 3.4 & 3.5 & 3.0 & 47.6 & 4.2 & 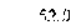 & 4.2 & 33.3 & 2.6 & 338 & 2. \\
\hline Frajce & 191.5 & 19.4 & 218.8 & 19.5 & : 99.4 & 17.5 & 220.8 & 19.4 & 222.2 & 17.t & $: 67.0$ & 13.2 \\
\hline Detulaty & 17.0 & 1.7 & 26.8 & 2.4 & 2.7 & 1.9 & 28.1 & 2.3 & 34.8 & 2.8 & 50.6 & 40 \\
\hline Span & 124 & 1.3 & 15.5 & 1.4 & 17.5 & 1.5 & 22.1 & $\therefore .8$ & 22.8 & $1 . x$ & 15.2 & $\therefore 2$ \\
\hline United KIngdom & 41.7 & 4.2 & 41.7 & 3.7 & 43.3 & 3.8 & $2 \% .3$ & 2.4 & 28.4 & 2.2 & 29.8 & 2.4 \\
\hline Devel:ping countities & 550.5 & 55.7 & 638.3 & 26.9 & 648.4 & 57.0 & 717.7 & 57.9 & 751.3 & 59.4 & 841.8 & 66.6 \\
\hline Of whic:tr: & & & & & & & & & & & & \\
\hline Africa & 450.1 & 45.5 & 540.7 & 48.2 & 5731 & 50.3 & 616.8 & 49.8 & 632.5 & 30.0 & $? 15.9$ & 56.6 \\
\hline Of which: Coble d'lvoire & 156.2 & {$[6.8$} & 202.5 & 18.1 & 222.1 & 14.5 & 233.6 & 18.8 & 222.7 & 17.6 & 227.7 & 18.0 \\
\hline Asia & 82.1 & $\$ 3$ & 77.8 & 6.9 & 55.0 & 4.8 & 79.9 & 0.4 & 88.6 & 70 & 97.1 & 7.7 \\
\hline of whtich: Prople's & & & & & & & & & & & & \\
\hline Repulitic of Chine ' & $5(5.9$ & $5 x$ & 34.8 & 3.5 & $2 \%$ & 53 & 54.2 & 4.t. & $54, ?$ & 4.3 & 67.5 & 53 \\
\hline Dite: $=$ & {$[8.3$} & 1.8 & 19.8 & 1.8 & 21.2 & 1.9 & 20 & $i .2$ & 34.6 & 2.4 & 28.9 & 2.3 \\
\hline 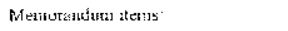 & & & & & & & & & & & & \\
\hline Shatre of tocat trade & & & & & & & & & & & & \\
\hline france & 198.4 & 16.2 & 223.7 & $15, \ddot{z}$ & $2(16.5)$ & $14 !$ & 204.1 & 13.3 & 225.6 & 15.6 & 7.5 & 0.5 \\
\hline Cote t'lverere & $10 \%, 1$ & 13.8 & 2000.7 & $1 \cdot 1.7$ & 225.3 & 160 & 235.5 & 15.4 & 2236 & 149 & 7.4 & 0.5 \\
\hline Gcraany & 20,7 & 1.7 & 29.7 & 2.1 & 25.5 & in & 328 & 2.1 & $34:$ & 2.6 & 1.3 & 0.1 \\
\hline
\end{tabular}

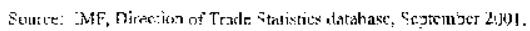



2 In:luding the furmer U.S.S.R. Eas ern Eutmpeur. cnentries, and otiners.

\section{CInternational Monetary Fund. Not for Redistribution}


Table 37. Mali: Terms of Trade Indices, 1995-2000

(Index, 1998=100)

\begin{tabular}{|c|c|c|c|c|c|c|}
\hline & 1995 & 1996 & 1997 & 1998 & 1999 & 2000 \\
\hline \multicolumn{7}{|l|}{ Export indices } \\
\hline Value & 67.6 & 66.9 & 99.0 & 100.0 & 106.2 & 114.3 \\
\hline Volume & 68.0 & 68.0 & 100.1 & 100.0 & 117.4 & 114.8 \\
\hline Inil value' & 99.4 & 98.3 & 98.9 & 100.0 & 90.4 & 99.6 \\
\hline \multicolumn{7}{|l|}{ Import indices } \\
\hline Value & 94.5 & 85.7 & 96.7 & 100.0 & 113.2 & 128.0 \\
\hline Volume & 94.7 & 87.4 & 94.7 & 100.0 & 108.0 & 105.9 \\
\hline Unit value $^{1}$ & 101.1 & 100.9 & 102.1 & 100.0 & 104.9 & 120.9 \\
\hline Terms of trade & 98.4 & 97.5 & 96.8 & 100.0 & 86.2 & 82.4 \\
\hline
\end{tabular}

Sources: Malian authoritics: and Fund staff estimates.

1 Unit value indices for exports and imports are Fisher indices valculated in lemass of CFA francs. 
Table 39. Mali: Foreign Aid, 1995-2000

(In billions of CFA francs, unless otherwise indicated)

\begin{tabular}{|c|c|c|c|c|c|c|}
\hline & 1995 & 1996 & 1997 & 1998 & 1.999 & $\begin{array}{r}2000 \\
\text { Est. }\end{array}$ \\
\hline Total foreign aid & 221.5 & 226.2 & 169.0 & 183.6 & 194.7 & 202.2 \\
\hline Grants & 111.4 & 124,1 & 96.3 & 99.7 & 103.0 & 107.2 \\
\hline Loans & 110.1 & 102.1 & 72.7 & 83.9 & 91.7 & 95.0 \\
\hline Project aid & 133.5 & 137.3 & 124.5 & 1.49 .4 & 147.4 & 157.1 \\
\hline Grants & 63.0 & 69.8 & 63.4 & 70.3 & 68.8 & 69.0 \\
\hline Loctrls & 70.5 & 67.5 & 61.1 & 79.1 & 78.6 & 88.1 \\
\hline Buidgetary aid? & 69.0 & 61.3 & 32.4 & 24.4 & 27.7 & 39). 1 \\
\hline Grants & 29.4 & 26.7 & 20.8 & 19.6 & 14.6 & 32.2 \\
\hline Loans & 39.6 & 34.6 & 11.6 & 4.8 & 13.1 & 6.9 \\
\hline Aid in kind (grants) & 5.5 & 6.1 & 4.1 & 4.1 & 4.1 & 6.0 \\
\hline Technical assistance & 13.5 & 21.5 & 8.0 & 5.7 & 15.5 & $\cdots$ \\
\hline \multicolumn{7}{|l|}{ Memurandunt ifems: } \\
\hline \multicolumn{7}{|c|}{$\begin{array}{l}\text { Percent of total foreign } \\
\text { assistance in the form of: }\end{array}$} \\
\hline Grants & 50.3 & 54.9 & 57.0 & 54.3 & 52.9 & 53.0 \\
\hline I.oms & 49.7 & 45.1 & 43.0 & 45.7 & 47.1 & 47.0 \\
\hline
\end{tabular}

Sormes: Malian authorities; and Fund staff estinates.

I In the balance of paynents, grants are included under oflucial trassfers; loans are inclucled in nonmonetary capital receints.

Includes budgctary aid channeled buth through the treasury and outside the treaslity. 


\begin{tabular}{|c|c|c|c|c|c|c|}
\hline & 1095 & 1996 & 1997 & 1995 & 1099 & $\begin{array}{r}2010 \text {, } \\
\text { list. }\end{array}$ \\
\hline & \multicolumn{6}{|c|}{ 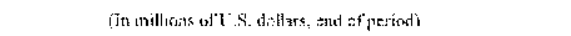 } \\
\hline Findextul its:tho:ic: $1 \mathrm{~s}^{2}$ & 33 & 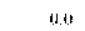 & $(1,0)$ & $n, 4$ & 9.7 & (b.1) \\
\hline \multicolumn{7}{|l|}{ Cfuticit } \\
\hline Netheriands & 23 & i) 0 & 0,0 & 0.3 & 0.0 & 0.9 \\
\hline Mut:ple istalers & (1) & $0.0)$ & 4.0 & 0.1 & 0.0 & 0.0 \\
\hline Siw torlardf & 0.0 & 0.0 & 0.0 & 0.1 & 0.0 & 0.0 \\
\hline L'nuted Kngngem & $0 . j$ & 0.0 & 0.0 & $0 . J$ & 0.0 & 0.0 \\
\hline Mulidaleral tuase & 1.3491 & 1.477 .63 & $1,288,4$ & $\therefore 960.8$ & $1,533.8$ & 1.637 .0 \\
\hline \multicolumn{7}{|l|}{ (f) rich } \\
\hline$y x$ & 32.1 & 370.8 & 347.4 & 386.3 & 39.7 & 591.8 \\
\hline BADIA & ló 4 & 12.3 & 112 & 52.2 & 9.6 & 4.6 \\
\hline fef & B.s & 8.4 & 2.5 & 7.8 & 0.8 & 6.8 \\
\hline EJEIR & 63.1 & 50.2 & $5: .2$ & 58.7 & 47.1 & $5 \times, 3$ \\
\hline FIn $A$ & 39.3 & 42.9 & $4 \overline{8} 8$ & $\angle B .3$ & 49.7 & 49.7 \\
\hline ID A & xh. & 1715.2 & 435,3 & $.0\} 0.7$ & $1,0,348$ & $1,0.34 .8$ \\
\hline Islami: Levelopmeat Bank & 31.0 & 32.3 & 35.7 & 35.8 & 0.0 & 0.0 \\
\hline Leuglic of Arab Siste 3 & 3.1 & 1.3 & $0 . R$ & 0.5 & 00 & 0.0 \\
\hline OPEC Sfecial Fured & 2.3 .3 & 21.4 & 18.9 & 19.0. & 14.5 & 14.9 \\
\hline 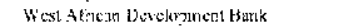 & 3.2 & R.0 & 30.2 & 21.7 & 25.4 & 25.4 \\
\hline Afritan Solidiatiy Fund & 2.5 & 2.5 & 2.3 & 2.4 &. .8 & 1.8 \\
\hline FCOWAS & $2 . \overline{7}$ & 2.3 & 1.9 & I.t: & $\therefore 8$ & 1.8 \\
\hline Hincenl ous & $1,397.7$ & $1,266.7$ & 1.219 .5 & $1,263.1$ & 1.269 .7 & (65).5) \\
\hline \multicolumn{7}{|l|}{ Ufwhichi } \\
\hline Alageria & $217 . .9$ & 187 & 159 & 137 & 11.5 & 96 \\
\hline Sistiztrardi & 0.0 & G.i & $0 . u$ & 0.6 & (b.) & 0,4 \\
\hline Ctitian, People's Repuhlia or & 1.37 .1 & 139.3 & 135.8 & $1,39.4$ & 13.3 .7 & 120.4 \\
\hline Cûte d l woit & $2, !$ & 7.5 & $? ?$ & 2.3 & 3.3 & 12 \\
\hline Egerph Arat kepsibles of & 3.t: & $11,: 1$ & 0.0 & 13,6 & {$[3,1]$} & $04\}$ \\
\hline firalice & 313.6 & 288.1 & 2334 & 319.9 & 273.3 & 2127 \\
\hline lraị & 20.0 & 20.9 & 200 & 250 & 25.0 & $20 . \vec{t}$ \\
\hline [isty & 2.7 & 1.3 & 11 & 1.7 & 1.0 & 09 \\
\hline jasun & 6.4 .1 & $x i t .3$ & 718 & $\left.x_{1}\right] .4$ & 38.5 & 76.8 \\
\hline Kuw at & 35.2 & 35.00 & $33 !$ & 32.2 & 31.1 & 349 \\
\hline Eiby:a & $? .2$ & 5.2 & 4.8 & 4.2 & 3.1 & 23 \\
\hline Netlirtlunds & 54 & $2 \ldots 5$ & $\therefore 1$ & $2 .{ }^{3}$ & $2 . i]$ & 1.8 \\
\hline Saud A Acama & 84.6 & i8.t & 134 & 71.4 & $6 h . ;$ & 54.1 \\
\hline Uniled anab Erı:To.es & $2 \dot{5} .1$ & 2.3 .6 & 214 & 1.7 .6 & 16.1 & 14.1 \\
\hline Uiriled Kiagulonn & $\vdots 5.6$ & IS.C. & 67 & 5.7 & 61 & 6.9 \\
\hline Ratixíl & 547.6 & 5.47 .6 & .547 .6 & 544.8 & 544.8 & 118.7 \\
\hline Suxota: & $2,699.0$ & $2,744.3$ & $2,7.38 .3$ & $7,560.9$ & $2,793.6$ & $2,327.4$ \\
\hline Lse: ut LAF rescatos & 147.2 & 164,8 & $: 75.7$ & $1 \$ 5.5$ & 193.1 & $: 25.5$ \\
\hline Tot:L & $2, x+46.2$ & $2,909.1$ & $2,3 \leqslant 4.6$ & $3,05 \%+$ & $2,987 . j$ & $\therefore 038.0$ \\
\hline \multicolumn{7}{|l|}{ Memorindum items: } \\
\hline & \multicolumn{6}{|c|}{ 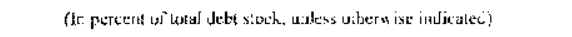 } \\
\hline Supplis:s & 0,0 & 1).0 & 0.0 & (i.t) & $0 . \mathrm{i}$ & 0.0 \\
\hline Finatic:al ins.jutions & i.1 & 0.1 & 0.0 & 0.2 & 0.3 & 0.0 \\
\hline \multicolumn{7}{|l|}{  } \\
\hline INfE Ttus: Fund & 34.2 & So: & 31 & $38 . i$ & 49.3 & 59.7 \\
\hline B:lateral lowi:s & 45.6 & 43.5 & 43.3 & 41.1 & 40.5 & 27.7 \\
\hline \multicolumn{7}{|l|}{ of nidith } \\
\hline Crinta. l'cople's repoutlic of & 1.8 & L.S & 4.7 & A.t & 4.5 & 4.1 \\
\hline France & 11.2 & 7.9 & 98 & $16: 5$ & 4.2 & 3,0 \\
\hline R.1ssis & 19.2 & is. & 14.0 & $i \bar{t}, \mathrm{~B}$ & $3: 2$ & 3.9 \\
\hline 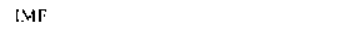 & $\therefore 2$ & $3 .:$ & 0.1 & t.l & 5.5 & 5.8 \\
\hline Exthange iale ClFA fraes per is toula" & s9ii.ti & 523.7 & $55 \mathrm{sin}$ & $\sin 2,2$ & 6.53 .0 & $7(6,5,11$ \\
\hline
\end{tabular}

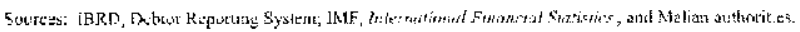

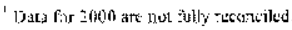

liat ot punod 
Table 40. Mali: Structure and Terms of New Loan Commitments, $1995-2000$

(In millions of U.S. dollars anless otherwise spesified)

\begin{tabular}{|c|c|c|c|c|c|c|}
\hline & 1995 & 1996 & 1997 & 1998 & 1994 & $\begin{array}{r}2000 \\
\text { Est. }\end{array}$ \\
\hline \multicolumn{7}{|l|}{ Categery of lender } \\
\hline Bikateral lotns & 61.9 & 7.7 & 0.0 & 22.9 & 42.1 & 4.0 \\
\hline Multilateral luans & 100.7 & 230.4 & $12,3.4$ & 90.9 & 202.7 & 230.6 \\
\hline Supplies' erecess & 0.0 & 0.9 & 0.0 & 0.0 & 06 & 0.0 \\
\hline Fintanial institutions & 0.0 & 0.0 & 0.0 & 0.0 & 6.1 & 9.9 \\
\hline Total & 162.6 & 238.1 & 123.4 & 113.8 & 251.2 & 243.0 \\
\hline \multicolumn{7}{|l|}{ Average terms } \\
\hline luteres: "zte (fercent) & 1.5 & 4.3 & 0.9 & 1.7 & 2.0 & 1.8 \\
\hline Maturiy (years) & 30.7 & 35.9 & 43.8 & 24.5 & 24.2 & 28.8 \\
\hline (irace period (years) & 8.8 & 9.3 & 9.9 & 7.0 & 3.4 & 6.9 \\
\hline Grat: element (porcint) & 68.6 & 73.3 & 79.7 & 65.8 & 58.1 & 51.3 \\
\hline
\end{tabular}

Sotres: BBRD. Debto: Reporting System; Malian authorities; and Fund and World Bank staft estimates.

' Data for 2000 are not fully reconciled. 
Table 41. Mali: Debı Service on Mediury- and Lung-Term External Public Debt, 1995-2000 ${ }^{12}$

$1995 \quad 1996 \quad 1997 \quad 1998 \quad 1999 \quad 2000$

Est.

\begin{tabular}{|c|c|c|c|c|c|c|}
\hline \multirow[b]{2}{*}{ IMF } & \multicolumn{6}{|c|}{ (In billions of CFA francs) } \\
\hline & 4.5 & 4.9 & 4.7 & 7.6 & 8.2 & 13.4 \\
\hline Charges and interest & 0.9 & 0.9 & 0.6 & 1.0 & 1.0 & 1.2 \\
\hline Repurchases and repayments & 3.6 & 4.0 & 4.1 & 6.6 & 7.2 & 12.1 \\
\hline \multicolumn{7}{|l|}{ Scheduled debt scrvice } \\
\hline (cxcluding China, Russia, and IMF) ${ }^{3}$ & 38.7 & 34.9 & 36.9 & 36.1 & 43.9 & 48.0 \\
\hline lnterest & 13.0 & 11.6 & 11.9 & 10.2 & 12.5 & 14.8 \\
\hline Principal & 25.7 & 23.3 & 25 & 25.9 & 31.4 & 33.2 \\
\hline \multicolumn{7}{|l|}{ Scheduled debi service } \\
\hline Interest & 13.9 & 12.5 & 12.5 & 11.2 & 13.5 & 15.1 \\
\hline Principal (excluding IMF) & 25.3 & 23.3 & 25.0 & 25.9 & 31.4 & 37.1 \\
\hline Repurchases to IMF & 3.6 & 4.0 & 4.1 & 6.4 & 6.6 & 9.2 \\
\hline & \multicolumn{6}{|c|}{$\begin{array}{l}\text { (In percent of exports of goods } \\
\text { and nonfactor services) }\end{array}$} \\
\hline Debi-service ratio vis-a-vis the IMF & 1.7 & 1.9 & 1.3 & 1.9 & 1.9 & 2.9 \\
\hline \multicolumn{7}{|l|}{ Debt-service ratio } \\
\hline (including IMF) & 16.4 & 15.1 & 11.1 & 11.4 & 12.9 & 13.3 \\
\hline Interest & 5.3 & 4.7 & 3.3 & 2.9 & 3.4 & 3.3 \\
\hline Principal & 11.1 & 10.4 & 7.8 & 8.5 & 9.5 & 10.0 \\
\hline & \multicolumn{6}{|c|}{ (In billions of CFA francs) } \\
\hline Debt rescheduling ${ }^{2}$ & 2.3 & 2.0 & 0.0 & 0.0 & 0.0 & 2.6 \\
\hline Debt cancellation & 2.0 & 0.0 & 0.0 & 0.0 & 0.0 & 0.0 \\
\hline Exports of goods and nonlactor services & 260.3 & 268.4 & 375.1 & 380.4 & 419.4 & 462.8 \\
\hline
\end{tabular}

Sources: Maiian authorities: and Fund staff estimates.

Preliminary data for 2000 , in process of data reconciliation.

2 On current debt-service obligations. 
Toble 42. Mali: Nominal and Real Effective Exchange

Rate Indices, 1995:Q1 - 2001:Q3 '

(It)dex: 1996 $=100)$

1935

First quarter

Second guartier

I'hird quarter

Fourth quarter

1996

Firs: chunter

Secord qua tet.

Thitd quarecr

Fourth cuarter

1997

First quarter

Second quartec

Third quartar

Fourth g̨!larter

$99 \bar{x}$

First quarter

Second yuarter

Third quartes

Fourtl equarler

1949

First quarter

Second quarter

Third quarter

Fourth iltiater

2600

First quat-er

Second quister

Third quarter

Fourth quarter

2001

First querter

Sccond quarter

Th:rd unarter
54.62

55.27

55.51

$55.7 \%$

55.51

55.02

5.5 .19

54.80

53.67

53.09

52.16

53.33

53.23

53.66

54.22

54.68

58.41

60.79

62.1

64.23

63.74

64.84

54.56

63.36

53.67

$\$ 3.09$

52.16

53.33

53.72

52.67

52.38

51.89

61.13

62.37

64.16

64.39

62.06

60.38

60. 36

$5 \times 91$

51.09

57.46

50.39

56.18

50.02

55.34

49.65

55.85

50.39

58.25

50.27

57.58

50.54

Source: IMF. Information Votice System (T.S.S).

${ }^{1}$ Period aterages. based on t)e following average trade weights fin percent) Fance (25.81), (ielmany (10.55), Uniled Siafes (8.57), I taly (8.38̈), Lnited Kingdon (6.36), Belgwin (6.34), Japan (5.61), the Netherlands (4.84), $P=0$ ple's Republic of China (4.50), and other countries (18.74). 
I. Tax cn income and profits

1.i Tax or modustial, sommercial, and Frofessional profits (IS-BIC)

\subsection{Miniming}

presumptive tax (LMF)

1.; Schedular tax on agricultaral profits ${ }^{1}$

1.2 Schedilar tax on rencal income (IRF)

1.5 Tax m road transporters (TTR
Tax on net insorce of enterprises, whener set up as comparies on rot, of some cooperarives, and of certain professions, and public ealerpr ises. Nentesideat companies are titxed en tiat past at thear protits derived in Mali. There ate spccial proxisions for the extractive ind surres. Lucses in deficit years may be carried forward and deducted trom the results of the following duree years.

Constitntes a mminm:am assessment fort ente.rises slibjicl to corpurate lux

L.cvicd on agricultural profiss and establisher on a lume-sum basis; option exists for laxarien on actual nrofits.

Exemptions: nonprofit consureer cooperatives withou sales outleis. mitual agriculturad cradit fudus. Piofity

subject to IRF and IRVM, axpayers sutjoct to

busiurss liven ie ters (patunte): snall transport

encrrrises, retionem: funds. and initial inves:munts in agricultare rescarch are also exermp:-

Special derlucti:ns: Jnder ceriain conditions, investment expenditure of up to 50 perzent of protits.

Levied on rental income from real estate $A$

withhulding is reyuired tatch month on monthly renlals of CFAF 100,000 or more at the following rates.

- 15 percent on rentals from dierable of 8.milurable constructiom; aid

- 11 percrint an rentals from nonclurahle construction.

Final tax na road trangponters (whose tarnowers to not excust (.FAF $5,000,000$ or who own fewer tian four vericles) in lion of the following taxes:

- busincss license fecs;

- $\mathrm{t} 3 \mathrm{x} \mathrm{nn}$ venicles:

- Faytroll tax for their emplayes

- general withloolding income tax for their employees;

- value-added tax; and

- tax on protits.
Liraiterl liability

uonpanics

(SA and SARI.):

35 percent

Partzerships

and individual

enterprises:

25 percen i1.75 peroent on urnover.

Exemption of five years for new ag̣icultural en:erprises

10 percent.

15 nercent. 


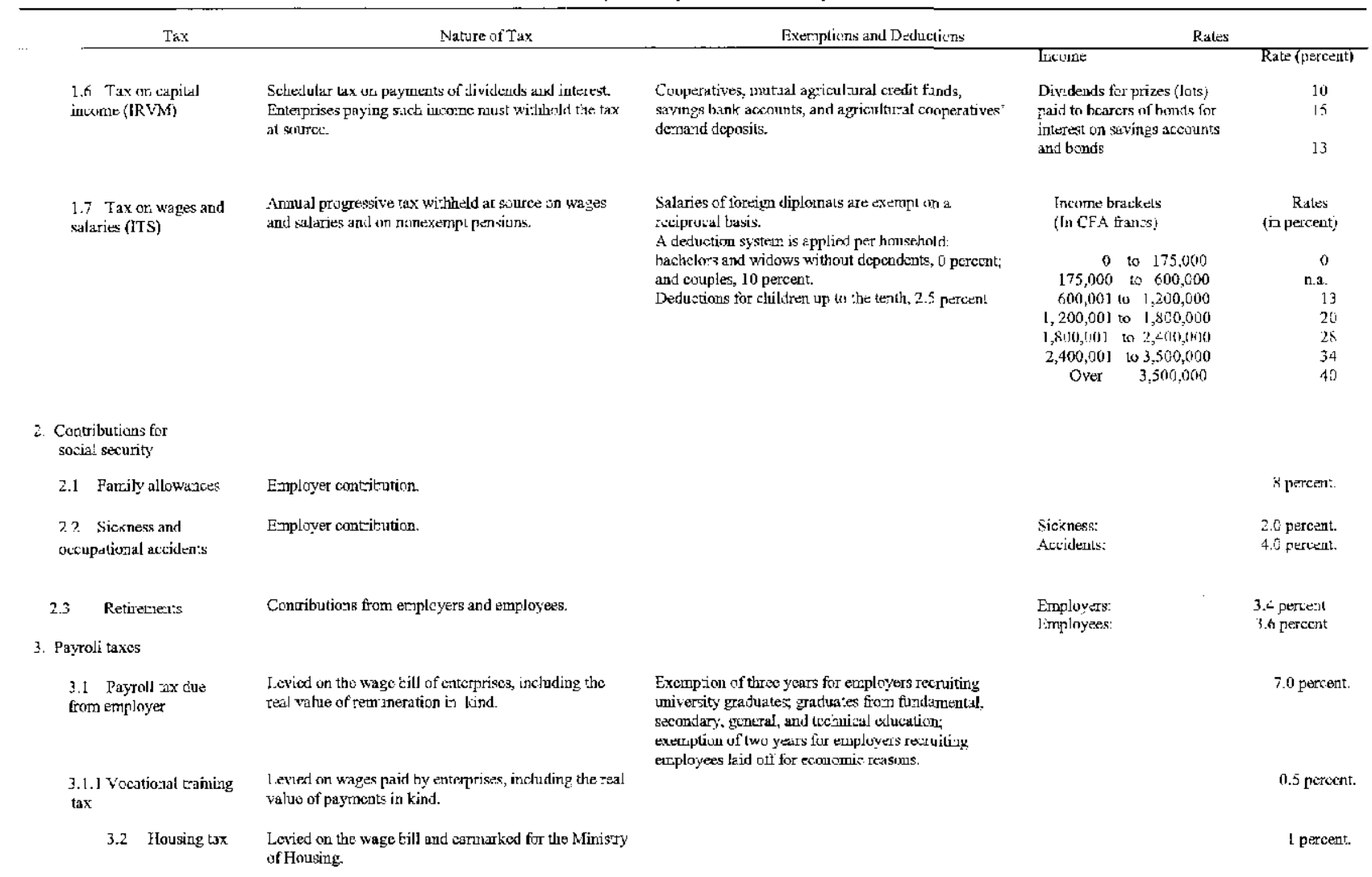

\section{(C) International Monetary Fund. Not for Redistribution}




\section{Taxcs on propety}

4. Registration fet

Applies, among ochers, 50 transfers of real estate.

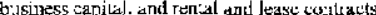

4.2 Livestock :ar:

\section{1 exied according to tie size of heds}

5. Tux un gusends and servites

S.1 Value-added tax (VAT)

5.2 Tax on financia activi:ites (TAF)

5.3 Sclective excises value-added tox itsel
Sf percent deducuion if the building is to be destroyed, and othar counditions as specitien in the lax code

\section{Sale of buildings and \\ transfer if resta}

contrac::

15 percent.

Rental contrast

feas:

Sale cr rental of

furniture:

Transfer of

busines:

3 percent.

10 percent

20 percer.t.

Certain fardo ammals

Tax varies according to

to CFAF 800 per head

18 percent.

Tax on imports, as well as sales of goods, consiruclio werk, and survisies. The base does not icclude the

Expurts, Lgricaltural equipment and inputs. and dugs.

Money markel operailons

15 percent

\section{(C) International Monetary Fund. Not for Redistribution}



contracts

5.10 innestic tax an petroloum products

6. Taxes on interna ional trade
6.1 Custun1s duties (1m mpots
Levied ou all incividuals or legal entities engaged in conmerce, industry, ur a profession in Malit T conprises a prenortional business license lict. calculated on the rental value of business rremises, and a fixes fex establishes hy area and type of activizy.

Levied on enterrises engaged in wholesale ur retai ale of alcoholic beyerages. They are establskhed at that sale of alcoholic beverages. They are establish
rates for two wrougs (Bamlako aril tither areas's.

Tax un vehic.es in use with license plates issued in

Anvial levy on firearms owncrs.

Levied on premiuzs paid for insurance contructs

Leviod ou imports and domestic* of fetcoleum proistucts.
Centrat and other administralive entities, and exports of livestuck and tixprayers winose anmual turnover does not exceed Ciral' 30 million

Parti.l exemptions: recent uriversity graduates during the tirst three years of activily on theit nWn account on a decliwi-y basis (100) percen., 50 percent, and 25 percent). Item for zivil servauts who leape, thenr jolss undex the voluntary d parture program, as well as for workers litid of for econemic reasons.

Exerptions: vehicles belcriging to the civilian and military autivuritics.

Exerptions: arms held by officers and arrs in stock.

Reinsurance contracts, irsurance for export credil, and life insurance contrats.

Oil lubricants and petrolourn derivatives excluded from WALMU! dermiliom
Propirtional ade.

10 percent.

Flat rates vaty from CFAF 7,200 to CFAF $1,000,000$

\section{Flal wates vary from CFAF 9,000} TO CFA" $1 \leq 0,000$

Based on vchicle power. varies form CFAF 7,000 to C'FAF 75,000

Variahle rates from CFAF 625 to CFAF 7,500 acourding to lype of fireams.

20 percert for all uther instiance wotracts

CFAF 0 to CFA 155 per kilugram

Ad valorem dotics at the rates of zero: 5 percent; 1 Fercent; and 20 porcent depending on the 
6.2 Temperacy import levied on the c.i.f value of noports of sugar, wheal $\operatorname{tax}(\mathrm{TCl}) \stackrel{{ }^{\prime \prime}}{=}$

6.3 VAT on imports

6.1 Regional solidarity

thx (I'CS)

6.5 Selective

excises on

imported goods

6.5 lyestining

protection

$\operatorname{tax}(\mathrm{TDP}){ }^{3 \prime}$

6.7 Kegional tax (PC)

6.8 Custorns service toe

Levied on the ci.f. value of imported goods from all

coint:ies for eustorns clearanes services providad by the Cuslurss Department.

6.9 Special tax un

petroleum inports

Leticti on ptroleum products. Tax base is a standard value deterwined by tie (ustoms Deparment.

7. Utter taxes

\section{Regional ard local} develnpment lax

(TDRI.)

72 Stcmp dudies

WAEMr

Levied on imported produces conpeting with local

pruducts. based on WAEMU regulations.

T.evied an thi w.i.C. value of gonds imported forn nocmenter comintries of the WAI:C:

Lexied on maividuals.

Children ander I 4 yoars aud students.

See 5.1 aboure.

f'stalcum troducts

Petzoleam products.
V'ariable rates deperndize on internationial prices for sugar, whesil loovi, und tioo.

See 5.1 above.

0.5 percint.

Variable rates betweers $S$ percent and

90 rercent.

\section{Maximus rate: 20 percent.}

Mininum rate: 10 percent

This tate declines every year, startiog in July 1999.

0.5 percent.

1 percet:

Six yariable tais by product: $5,6,10,25,93$, und 123 percent

Variahle zates by regiom (Eom CFAF 875 th CF.AF $3.0 \mathrm{CO}$ )

Rates are tixed accorcing to the nature of the logal dowment.

\section{(CInternational Monetary Fund. Not for Redistribution}






